Suggested short title

MORPHOLOGICAL COMPARISON OF ANTIPODEAN TELEOGRYLLUS SPECIES

G. T. Chen 


\section{A MORPHOLOGICAL COMPARISON OF ANTIPODEAN \\ TELEOGRYLLUS SPECIES (ORTHOPTERA: GRYLLIDAE)}

by

$$
\text { G. T. Chen }
$$

A thesis: submitted to the Faculty of Graduate Studies and Research, McGill University, as partial requirement for the degree of Master of Science.

December 10, 1965 


\section{ACKNONLEDGNENTS}

The author vishes to thank Professor D. K. MeE. Kevan and Dr. V.R. Vickery for their valuable advice and assistance. Thanks are also extended for special assistances from Dr. R.L. Randell and the laboratory technician Mrs. E. Smythe. A grant from National Research Council of Canada is gratefully acknowledged by the author. 
TABLE OF CONTENTS

Page

I. Introduction

II. Review of Previous Work

III. Materials and Methods - 7

A. Materials Used and Their Sources 7

B. Characters Studied - 8

C. Sampling Method - 10

D. Preparation of Slides - 11

E. Examination - 12

F. Analysis -

IV. Results - 15

A. Proportions of Body, Frons and Pronotum

B. Number of Stridulatory Pegs - 16

C. Proportions of Fore-leg and Tympanum

D. Proportions of External Genitalia - 19

E. Proportions of Epiproct

F. Proventriculus - 22

V. Discussion and Conclusions -

VI. Summary - 29

VII. Bibliography - 31 Appendices
A. Tables: I to XLI
B. Figures: 1 to 40 


\section{INTRODUCTION}

The common "black" field crickets from different areas of Australia and New Zealand have generally been treated previously as belonging to a single species, Teleogryllus commodus (Walker), although other related species, such as I. oceanicus (Le Guillou) have been recorded from various parts of Australia (see Chopard (1951) and Leroy (1964a)). Owing to close morphological similarities among allopatric specimens, no critical attempt to separate morphological species was made until this was done by Leroy (1964b). However, studies from physiological and genetical approaches have been made by several authors, who have shown that "I. commodus" populations constitute different entities isolated reproductively as well as physiologically (Browning, 1952a, 1952b; Hogan, 1960; Bigelow, 1962; Bigelow and Cochaux, 1962; Cochaux, 1964; and Leroy, 1963, 1964a, 1964b).

Recently, Leroy (1964b) has shown that, on the basis of the morphology of the sound-producing organs, Australian Teleogryllus commodus and Pacific Island Teleogryllus oceanicus are clearly different. Leroy's results have thus indicated that it is possible to differentiate members of the commodus group by means of morphological characters. The present work, begun before Leroy's (․ㅡ‥) work was published, attempts to differentiate Antipodean populations formerly 
referred to $\underline{T}$ - commodus by comparing morphometrical characters statistically. 


\section{REVIEW OF PREVIOUS WORK}

Browning (1952a, 1952b) and Hogan (1960) studied the diapause characteristics of the eggs of Teleogryllus commodus from South Australia and the State of Victoria and showed that the proportion which enter diapause varies with different incubating temperatures. Hogan (1960) found that 16 per cent. hatched at $26.7^{\circ} \mathrm{C}$ without evidence of diapause, 64 per cent. at $29.4^{\circ} \mathrm{C}$, and 83.3 per cent. at $34^{\circ} \mathrm{C}$.

Bigelow (1962) found that a population, which he called T. commodus, from Ingham, Queensland (designated by him as Qn), differed from a South Australian (Adelaide) population (which he designated as Qa) in the length of incubation period at $28^{\circ} \mathrm{C}$, and that sterile hybrids were produced by crossing the two populations. A third population from Victoria (designated QC), had two different hatching rates at $28^{\circ} \mathrm{C}$. It comprised a faster hatching group, the eggs of which had an incubation period of about 15 to 20 days, and a slower hatching group, which required from 35 to 85 days incubation. However, fertile hybrids were produced between $Q a$ and Qc. Thus Bigelow claimed that the Qn strain might be a different species from the other two, but that it was also possible that the three strains might be interconnected by an unknown series of interfertile populations. 
In a genetical and physiological study of the same strains, Bigelow and Cochaux (1962) found that the $F_{1}$ offspring of the cross between $Q c$ and $Q a$ produced large numbers of $F_{2}$ progeny, which in turn produced many healthy $F_{3}$ nymphs. However, the $F_{1}$ offspring from crosses between either $Q n$ and Qa, or Qn and Qc were sterile. As to the physiological aspect, a discrepancy was found between the results of their initial and later experiments on diapause of eggs. Their initial results showed that the proportion of eggs that hatched without diapause at $28^{\circ} \mathrm{C}$ was different in the three strains. Their later results, however, showed that an increase in the proportion of eggs hatching without diapause occurred in both of the southern strains; i.e., in $Q a$ and QC. "These differences," the authors suggested, "probably involve different gene frequencies rather than different genes, and the gene frequencies can probably be altered rather quickly in response to climatic changes". Bybrid eggs which were obtained by either crossing or reciprocal crossing $Q$ n with $Q$ a, and Qn with Qc all hatched without diapause. Thus the authors believed "some sort of dominance is exerted by nondiapause over diapause genes".

Cochaux (1964) showed that the hybrids from crosses of either Qn with Qa, or Qn with Qc, or their reciprocal crosses, were all sterile. There was no sexual activity; nevertheless 
both sexes were alive and vigorous. The females did not lay eggs since the ovaries were not functional. He also found that the speed of development varied between sexes of each type of hybrid. The results showed that the length of development of nymphs was longer if the male parent was $Q n$ and shorter if the female parent was Qn.

Leroy (1963) has shown that the different parametric rhythms and the characteristic frequency of the sound signals of the $F_{1}$ produced by crossing $\underline{T}$. commodus (assumedly from Canberra, Australian Commonwealth Territory; Burnley, Victoria; and Adelaide, South Australia - see Leroy (1964a)) with T. oceanicus (assumedly from either Brisbane, Queensland, or Tahiti - see Leroy (1964a)) were intermediate between those of the parents. In a further study on the hereditary transmission of the sound frequency in hybrids of the same species (or strains as assumed by former authors), Leroy (1964a) showed that hundreds of $F_{1}$ were obtained from crossing $\underline{T}$. commodus with $T$. oceanicus but only a few adults appeared in the back-cross, only about ten males being able to stridulate. The signals of courting and fighting had the same characteristic frequency as those of mating for all the hybrids of the first generations. However, the sound produced by the hybrids of the back-cross had a frequency which was neither that of the $F_{1}$ nor of the parents. 
Recently Leroy (1964b) has shown a structural difference in the sound-producing organs between the two species: T. commodus has a lesser number of pegs (about 170) on the stridulatory vein than $\underline{T}$. oceanicus (with more than 240 ).

Bigelow and Cochaux (1962) described some minor and overlapping differences in coloration and in the shape of the proventricular teeth between the Queensland population ( $Q n$ strain) and the southern strains (Qa and Qc). Cochaux (1964) has mentioned that morphologically these strains are not different except in certain configurations of the teeth of the proventriculus. Further information, both qualitative and quantitative, on morphological differences between Australian Teleogryllus crickets is wanting; no information of this kind exists for New Zealand populations. 


\section{MATERIALS AND METHODS}

\section{A. MATERIALS USED AND THEIR SOURCES}

Specimens from six strains of Teleogryllus crickets origniating in different geographical areas of Australia and New Zealand were studied. The strains had been in culture at Macdonald College of McGill University for several generations. The original Australian strains were obtained from the following locations: Adelaide (South Australia) - hereafter referred to as Qa; Perth (Western Australia) - Qw; Ingham (Queensland) - Qn; and Burnley (Victoria) - Qc. The New Zealand strains were from Kaikoura (South Island) - Qk - and Auckland (North Island) - Qz.

Adult crickets of each of these six strains were maintained separately in $24 \times 18 \times 16-$ inch glass-walled and screen-covered cages on a diet of commercial "baby rabbit pellets" (manufactured by Ogilvie's Flour Mills, Montreal). Fresh grass was given occasionally. Water was supplied regularly in J-shaped glass vials ( $5 \times 1 \frac{2}{4}$ inch) plugged with absorbent. cotton. Paper strips were provided for shelter. Clean, moist sand contained in plastic Petri dishes was provided for oviposition. Twice each week, the sand dishes containing the eggs were removed to an incubator at a temperature of $28^{\circ} \mathrm{C} \pm 1$ and a relative humidity of 95 per cent., and replaced with new 
ones immediately. Dead and dying crickets were preserved in 70 per cent. alcohol. Since the primary purpose of the investigation was to compare the morphology of the different strains, only preserved specimens were used; immature stages were not considered.

\section{B. CHARACTERS STUDIED}

In comparing the six strains studied, measurements were made of the following: the length of the body exclusive of appendages (mm.); the maximum width of the prothorax of intact specimens (mm.); the dimensions of the frons (mm. - see Fig. 1); the overall dimensions of the pronotum dissected off and flattened (mm. - see Fig. 2); the number of pegs on the stridulatory veins of the tegmina (left and right); the length of the anterior femora and tibiae (mm. - see Fig. 12); the length and width of the tympanum on the exterior face of the fore tibia, measured as in Fig. 13 ( 1 unit $=0.015 \mathrm{~mm}$ ); the dimensions of the ectoparameres of the male genitalia and of the second valvifer of the female genitalia (mm. - see Figs. 19 and 20); the dimensions of the epiproct (mm. - see Fig. 
21); the height of the proventricular teeth measured as in Fig. 40 ( $I$ unit $=0.0063 \mathrm{~mm}$ ); and the number of the denticles of the proventricular teeth (Fig. 40).

Since individual members of a population may vary considerably in size, and also because the various parts of the body have allometric growth, comparisons of ratios of different parts of the body are more appropriate than single absolute measurements. The ratios of measurements used to compare strains were as follows: the length of the body over the width of the prothorax (of intact specimens), the length of the frons over its width, the total (dorsal plus lateral) width of the pronotum over its length, the length of the anterior tibia over that of the anterior femur, the longitudinal over the transverse diameter of the tympanum, the length of the ectoparamere of male genitalia over its width, the length of $A B$ over that of $A C$ (Fig. 20) for the second valvifer of the female genitalia, and the length of epiproct over its width. Since the bases of the proventricular teeth are not clearly defined, an exact measurement of their widths was hard to make. Therefore, for the proventricular teeth no ratios were calculated and only absolute measurements of height were used. 


\section{SAMPLING METHOD}

In order to measure accurately the individual variation within strains, a different sample from each was used to study each different norphological character, except in the study of the morphology of the fore-leg and tympanum, where the same sample was used for the two characters in each strain. Twenty specimens ( 10 males and 10 females) were taken from each population or strain at random and used for studying such characters as the proportions of body, frons, pronotum, fore-leg and auditory organ. Since the structure of the external genitalia and the shape of the epiproct are clearly different in the two sexes, and a fully developed stridulatory vein exists in the male, only 10 individuals of one sex were used in studying these characters. In comparing the numbers of denticles and the heights of the proventricular teeth, five individuals of each sex of each strain were compared with similar samples from the other strains. Since, in this case, the variables are the teeth themselves, the actual sample size for each strain was, therefore, not 5, but 72 (the tooth number for each individual) $\times 2$ (sexes) $\times 5$ (number of individuals), or 720 .

The sampled specimens were preserved individually in 70 per cent. alcohol in small glass vials, and each specimen was given a random number. In studying any particular chara- 
cter, the portion of the insect concerned was removed and the remainder of the insect returned to the original population, so that such used specimens might be sampled again for studying a second or subsequent character.

\section{PREPARATION OF SLIDES}

Slides were prepared as follows:the portion of the insect to be examined was treated first in 10 per cent. cold $\mathrm{KOH}$ solution for 16 - 24 hours, to digest muscles and other tissues, and then rinsed with tap water and distilled water three times each. All materials were treated in the same way and then kept in their original containers with 70 per cent. alcohol.

Polyvinyl lacto-phenol ${ }^{l}$ was used as the mounting med-

1. Commercial polyvinyl alcohol (Elvonol, type A, 51.A.05, Hartman-Leddon) - 2.5 grams

Lacto-phenol solution ( 45 grams phenol detached crystals in $45 \mathrm{cc}$. of lactic acid) (Beirne, 1955). 
ium. A drop of the medium was placed on a clean slide and a piece of the treated material inserted into the medium. A cover-glass was then applied, and the slide marked with an inscriber giving details of the source of the material, the sex, the random number, etc., and dried.

\section{E. EXAMINATION}

The prepared slides of the proventriculus and wings were examined under a binocular compound microscope (eyepieces $10 \mathrm{X}$ objective 10). A $10 \mathrm{~mm}$. calibrated micrometer was used to measure the height of the teeth of the proventriculus (Fig. 40) and the diameters of the tympana (Fig. 13), and the latter was measured under an uniocular compound microscope (eye-piece $4 \mathrm{X}$ objective 10). A hand-counter was used when counting the number of pegs on the stridulatory vein.

A rectangular block of wood was used in measuring the length and the width of the body. An insect pin was put vertically into the wood. The preserved specimen was straightened and set on the wood with the ventral side up. The head 
of the insect was closely adpressed to the pin. A second pin was applied perpendicularly at the tip of the abdomen. The insect was then removed and the distance between the two pins measured to the nearest $\mathrm{mm}$. by means of a centimeter scale. As the prothorax is rigid and has a constant shape, it was taken to represent the width of the body and measured in a similar way as for the length of the insect.

As it was not possible to make a satisfactory slide of the hemispherical head, a special measuring device was used. A plastic ring with a diameter of $15 \mathrm{~mm}$. and a height of $4 \mathrm{~mm}$. was sealed to a clean slide by means of wax paraffin around the outer edge of the ring. The head of a decapitated cricket was put in the ring and covered with the micrometer slide and the measurements made under a dissecting microscope. The length and width of the frons, as illustrated in Fig. 1, were measured from the apex to the fronto-clypeal suture and from one mesal edge of the antennal sockets to that of the other.

A binocular dissecting microscope (Wild, Heerbrugg, M5-51029) with an attached camera lucida (Wild) was used for drawing figures. A desk calculator (Monroe, CSA-8, 63673I) was used for making calculations. 


\section{F. ANALYSIS}

Owing to close morphological similarity in the six strains studied, it is very difficult to compare them by qualitative means. The interpretation of the findings in the present work is therefore based mainly on statistical analyses of data obtained by measurements. Analysis of variance (Steel and Torrie, 1960) was used for testing differences between strains, within strains and between sexes. The t-test (Steel and Torrie, op. cit.) was also used to compare two sample means in those cases in which there was a significant different between strains. 


\section{RESULTS}

\section{A. PROPORTIONS OF BODY, FRONS AND PRONOTUM}

In comparing the ratios of the measurements of length to width of the body and frons and of width to length of pronotum, twenty specimens, ten of each sex, were drawn from each strain. The analysis of variance, for these data, as tabulated in Tables I, $V$ and IX, shows clearly that in every case the main factor 'strain' is significant. The significant 'strain $\mathrm{X}$ sex' interaction, as shown in Table $\mathrm{V}$ for the frontal ratio, implies that the differences among strains are influenced by the differences which exist between sexes, and vice versa. A comparison of sample means between strains of each sex, as shown in Tables II, VI and $X$, shows that for each character the results for the two sexes within a given strain do not always coincide. This, however, is not surprising as. there is morphological sex differentiation within certain strains. Means and the ranges of ratios of the measurements for each of the three characters mentioned are tabulated in Tables III, VII and XI, for both sexes of each strain. The low value of standard deviation in each case suggests that the observed values do not deviate much from the calculated means. Means of actual measured dimensions for each character are listed in Tables IV, VIII and XII. It is clear, from the range of measurements, that in each character, the observed 
values overlap each other both in sexes and strains. These characters cannot therefore be used satisfactorily to separate single specimens of these various strains.

\section{B. NUTBER OF STRIDULATORY PEGS}

Tegminal sound-producing organs were studied in males of all six strains. The numbers of pegs on the stridulatory vein of each tegmen were compared. for ten males of each strain. In Table XIII, the analysis of variance shows that differences in the number of pegs for both strain and side are significant. The results of comparison of sample means between strains for each tegmen, as listed in Table XIV, show no conformity between the tegmina of the left and right sides in certain strains. The morphological difference between the two tegmina in a single strain is perhaps due to a functional need, since from the means tabulated in Table XV, the right tegmen, which is almost always on top, usually has a larger number of pegs. It was found, from the data listed in Table $X V$, that the numbers of pegs on the flles of both tegmina in the Qn strain are far greater (a mean value of 257.5 on the 
right tegmen and 252.6 on left) than in other strains. In addition, the shape of the pegs in Strain on differs from that of the other strains (Fig. 3 to 8). These findings agree with those of Leroy (1964b, fig. 6). Therefore, by using these characters, it is easy to differentiate between Strain Qn and the others?

\section{PROPORTIONS OF FORE-LEG AND TYMPANUM}

Statistical analysis of the ratio of tibia to femur length and of length to width of the tympanum on the exterior

2. A dry specimen from Hawaii of what appears to be correctly called Teleogryllus oceanicus was examined. This was found to lack a smali triangular cell which is constantly present at the tip of the tympanic membrane of the tegmen in Strain Qn, as shown in Figs. 10 and 11 , but the number (246) and shape of the pegs on the file of the right tegmen were similar to those of Strain Qn (see Figs. 5 and 9 ), which is thus probably referable to $T$. oceanicus or $a$ very closely related species. It is also of interest to note that in a series of Teleogryllus from Easter Island, the number of teeth varied from 166 to 191 ; i.e., within the range of $T$. commodus and not of $T$. oceanicus to which this population had been referred by chopard (1924) and subsequent authors. 
face of the fore tibia shows that the differences among strains are highly significant for both characters, but that no difference between the sides of the insects occurred in ahy case (see analysis of variance in Tables XVI and XX). The latter result, however, was not unexpected, since it can be presumed that the development of the fore-legs and tympana, in relation to their respective functions, would be symmetrical. The ratio mean, which is an average value for the two sides, compares each sex of each strain with the corresponding sex of another strain for each of the two characters. A comparison of sample means between strains for the two characters is shown in Tables XVII and XXI. The results show no conformity between the sexes for each strain in the two characters (excepting that for Strain $Q k$ in the ratio of tympanal measurements). However, from the tabulated results shown in Table XVII, it is found that Strain Qn males are always different from the others in the mean of ratio of the fore-leg measurements. Also, the females of the Qn strain differ in the mean of ratio of tympanal dimensions (see Table XXI) from all of the rest, except Qk. It is also found, from Table XXI, that Strain $2 k$ is different in both sexes from the other strains, except $Q n$, in its ratio of the diameters of the tympanum. Data listed in Tables XVIII and XIX, like those in Tables XXII and XXIII, show the means of ratios and their ranges, and the 
mean value of measured dimensions for each sex in all the different strains. It is interesting to find that the female, with the exception of the Strain Qa, has always a large tympanal ratio (i.e. the tympana are longer or narrower). This may be due to a functional need, since, in courtship, the roles of the two sexes differ, the female always being the passive member. Just what the difference in function may be, and how the shape of the tympanum affects this, is difficult to surmise.

\section{PROPORTIONS OF EXTERNAL GENITALIA}

The structure of the external genitalia for each sex is basically the same in all strains (Figs. 14 to 20). The dimensions of the ectoparamere of the male and of the second valvifer of the female, as illustrated in Figs. 19 and 20, were measured for ten individuals of each sex of each strain. In every case the analysis of variance showed highly significant differences among the strains for each of the characters (see Table XXXV and Table XXV). A comparison of sample means between all possible combinations of strains, as listed in 
Table XXVI, shows that in each case, the ratio mean of the ectoparamere dimensions for males of Strain Qn is different from that of the other strains. However, in females of the same strain $(Q n)$ the results do not exactly correspond with those of the males. From the data given in Table XXVII, it is demonstrated that the ratio mean values for the two characters discussed above is larger in Qn males than in the males of other strains. The ratio mean for Qn females, on the contrary, is smaller than that of females of the other strains, with the exception of the Qz strain. Table XXVIII and Table XXIX show the means of actual dimensions from which the ratios were obtained.

\section{E. PROPORTIONS OF EPIPROCT}

A more useful and reliable morphological character that can be used for identifying the different strains, discovered in the present work, lies in the morphology of the epiproct. The shapes of the posterior margin and of the postero-lateral pigmented areas of the epiproct are clearly different for each strain (see Figs. 22 to 39). This feature is very constant 
for both sexes within Strains Qa, Qw and $Q n$, and it is also constant in female $Q k$, but less so in $Q k, Q z$ males and $Q z$ males, while it varies greatly within both sexes of Strain Qc (see Figs. 32 to 39). The ratios obtained from the dimensions of epiprocts of each sex, were also compared: The results of analysis of variance and of the comparison of sample means: between strains of each sex are shown in Tables XXX, XXI and XXXII. From the results listed in Table that the ratio of epiproct measurements in the female of Strain Qn is different from the same sex of other strains, but no difference is found between $Q a, Q w, Q k, Q z$ and $Q c$. In the male, however, the results afe not the same as for the female. It is found that the $Q n$ is different from Strains Qa, Qw, Qk, Qz and Qc. Qz is different from $Q w, Q k, Q c$ but not $Q$ a. It is also found that $Q \mathbf{a}$ is different from $Q w_{2} Q k$ and Qc, however, there is no difference between the last three strains. The ratio means and the means of the measured dimensions are tabulated in Tables XXXII and XXXIV. 


\section{F. PROVENTRICULUS}

The morphology of the proventriculus is rather complicated. The outer shape of the proventriculus resembles that of a pear, and its inner wall contains many sclerotized teeth, which, depending on how one looks at them, are arranged in twelve transverse rows or six vertical columns. In each row there are six teeth, or conversely, in each column there are twelve teeth. The total number of proventricular teeth is 12 X 6, or 72. Each tooth bears several denticles, each of which is either slender with a sharp point, or stout with a blunt point. The features of the teeth, howerer, vary within strains: as well as among strains.

The analysis of variance, as shown in Tables $X X X V$ and XXXVIII for each of the two characters, indicates that the factors, strains, replication, individual, and row, are all highly significant. The larger calculated value of 'row' in both cases, implies that the difference between rows is more significant than that for the other factors. A comparison of sample means of denticles and of tooth-height between rows of strains is shown in Table XXXVI and Table XXXIX. Since there is a highly significant difference between replications and that of the individuals, the differences between the rows in the various strains scarcely enable one to conclude that any 
one of the strains is significantly different from the others. In addition to this, the inconsistency in the form of the teeth also sho'ss that the reliability of this character is questionable. Therefore, the author would not place much confidence in tooth-form. The means and the range of means in respect to the tooth characters are tabulated in Tables XXXVII and XL. The high value of standard deviation implies a wide spread in the measurements of the individuals in each strain. 


\section{DISCUSSION AND CONCLUSIONS}

The analysis of the data discussed above shows that when a character from one strain is compared with that from the others the results are not always in agreement between sexes or between sides (right and left) in the same strain. This is, of course, owing to the morphological differentiation between the sexes, and also between the sides in the case of the tegmina. It was also found, that the results obtained from a comparison between two strains for one character did not necessarily conform with those obtained when another character was compared for the same two strains. This, however, nay be explained on the basis of the hypothesis that the same morphological feature or features occurring in different strains may have followed the same pattern of evolution.

The results of the present study are summarized in Table XII. They show statistically that in every case Strain Qn is different from $Q W$, and, with few exceptions, also from $\mathrm{Qk}, \mathrm{Qz}, \mathrm{Qa}$ and $\mathrm{Qc}$. In the case of the last two strains, the present findings agree with those of former workers obtained by adopting different approaches. This enables one to conclude that Strain Qn belongs to different group from the rest. It should, in fact, be referred to as Teleogryllus oceanicus (Le Guillou). 
Chopard (1951) recorded both Gryllulus (= Teleogryllus) commodus and oceanicus from various areas of Australia. Chopard's key ( 0.408 - 409) for separation of these two species is based entirely upon size, which is not reliable on a qualitative basis. It is thus probable that the locality records of Chopard are not valid for the species under which they are listed, as some of the records listed for oceanicus are undoubtedly of commodus, and vice versa.

The relationship between Strains $Q w$ and $Q a$ is very ambiguous. From the tabulated results (see Table XII) it seems that there are few differences between the two strains. However, when the shape of the epiproct (see Figs. 22 to 25) is taken into consideration, it is shown clearly that they differ. Moreover, a vast geographic distance(about 1400 miles) is involved between Perth (Western Australia) and Adelaide (South Australia), the respective sources of the two strains. Therefore, it is possible that a series of bio-geographic entities, differing slightly from each other, may exist between the two populations. However, until further genetical and physiological evidence is obtained, it is scarcely possible to clarify the relationship between $\mathrm{QW}$ and $\mathrm{Q} \mathrm{a}^{3}$.

3. The two strains interbreed freely in the laboratory, producing interfertile hybrids. 
It was found that the morphological divergence between Strain $Q w$ and the two New Zealand strains, $Q z$ and $Q k$, are much greater than those between either $Q w$ and $Q a$, or $Q w$ and $Q c$. This, however, is not unexpected, since the islands of New Zealand are widely separated geographically from the Australian continent.

No significant differences are apparent among Strains $Q a, Q c$ and $Q z$ even though the last is geographically isolated from the former two. It was found, however, that Qk differs in certain respects from all three. The considerable morphological diverence between the tro New Zealand strains was quite unexpected in view of the fact that only a single species was formerly believed to be involved, and this renders the situation more complex.

It may be assumed that Strain $Q z$ originated as migrants from Australia and is derived from similar ancestors to those that gave rise to $\mathrm{Qa}$ and related south-east Australian strains. The South Island strain, Qk, may perhaps have been derived from the same source. After the two New Zealand

4. It was found that the two New Zealand strains, QK and $Q z$, can interbreed freely in the laboratory (from data unpublished) and produce fertile hybrids. 
strains had existed in different bio-geographic circumstances for a long period of time, morphological divergence would not be unexpected. It is also possible, however, that introduction into the two main islands of New Zealand occurred at different times. The South Island strain, Qk, since it shows greater divergence, could have been introduced at an earlier period of time, or possibly from a non-Australian (i.e. Oceanic) source.

From the above, one can conclude that the Australian and New Zealand crickets, formerly known collectively as Teleogrvilus commodus, are made up of at least two different species: . commodus (Walker) and $\underline{T}$ - oceanicus (Le Guillou).

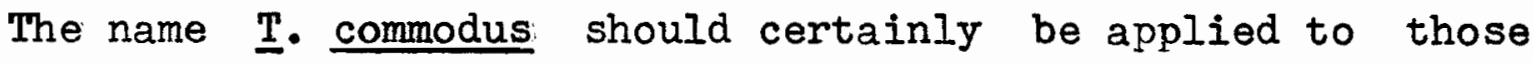
crickets from Western Australia (OW) whence the type of this species was originally described. The name $\underline{T}$. oceanicus should be applied to those from Queenszand $(Q n)$ and Leroy (1963, 1964a) has correctly used $\underline{T}$. oceanicus to refer to a population from Brisbane, Queensland.

Strains Qa, Qc and Qz should be treated either as distinct bio-geographic entities of $\underline{T}$. commodus or, as suggested by Bigelow (1962), the name servillei (Saussure, 1877) should be reapplied to these eastern populations. If the latter course of action were adopted, available evidence would indicate only subspecific status for the eastern forms. 
The position of Strain Qk is the most difficult to determine. It appears reasonable to treat it as a geographic isolation product of the "servillei" group of $\underline{T}$. commodus which has now attained, or is in the process of attaining the status of a distinct subspecies. This hypothesis will require substantiation by genetical and physiological experimentation such as that at present in progress at Macdonald College of McGill University. 


\section{SUMMARY}

The morphology of six populations of Teleogryllus, the common "black" field crickets, from different geographic areas of Australia and New Zealand were compared by means of mathematical methods. These populations are designated Qa, Qw, Qn, Qc, Qk andi Qz.

Statistically, it is shown that the Qn strain from Queensland is morphologically quite different from the others. The morphology of the sound-producing organs in the Qn strain is very similar to the Hawaiian species which is apparently correctly called Teleogryllus oceanicus (Le Guillou). In this character the Qn strain is also very similar to the Pacific Island (Tahiti) population of Leroy (1964b) and presumably identical with her Queensland material. Hence, the name $\underline{T}$. oceanicus is applicable to Strain Qn.

The population Qw from Western Australia whence Teleogryllus commodus (Walker) was originally described, is different from the South Australia ponulation ( $Q$ a) in certain minor morphological aspects. Therefore, if these populations should prove to be distinct, the $Q$ w not the Qa population would be referable to true $\underline{T}$. commodus (Walker).

Since there are no significant differences between strains Qa, Qc (from Victoria) and Qz (from North Island, New 
Zealand), it is reasonable to assume that they represent a series of closely related bio-geographic products of $Q w$, to which the name servillei (Saussure) might be applied in a subspecific sense.

The Ok strain (from South Island, New Zealand) is believed to be a divergent member of the south-east Australian group. Both genetical and physiological evidence now being accumulated is necessary to clarify the position.

An interesting secondary observation is that in all strains except $\mathrm{Qa}$, the female tympanum is longer or narrower than in the male, although the reason for this is unknown. 


\section{BIBLIOGRAPHY}

*Alder, H. L. and Roessler, E. B. 1960.

"Introduction to Probability and Statistics".

W. H.

Freeman and Company, San Francisco and London.

*Alexander, R. D. 1957.

The taxonomy of the field crickets of the eastern United States (Orthoptera: Gryllidae: Acheta).

Ann. Ent. Soc. Amer. 50:554-602.

Beirne, B. P. 1955.

"Collecting, Preparing and Preserving Insects".

Science Service, Entomology Division, Canada Department of Agriculture.

"Bigelow, R. S. 1960.

Interspecific hybrids and speciation in the genus Acheta (Orthoptera: Gryllidae).

Canad. J. Zool. 38:509-524.

Bigelow, R. S. 1962 .

Factors affecting development rates and diapause in field crickets.

Evol. i6:396-406.

Bigelow, R. S. and Cochaux, P. 1962.

Intersterility and diapause differences between geographical populations of Teleogryllus commodus (Walker) (Orthoptera: Gryllidae). Aust. J. Zool. 10:360-366.

Browning, T. $0.1952 a$.

The influence of temperature in the completion of diapause in the eggs of Gryllulus commodus (walker). Aust. J. Sci. Res. B5:112-127. 
Browning, T. O. $1952 \mathrm{~b}$.

On the rate of completion of dianause developnent at constant temperatures in the eggs of Gryllulus commodus (valker). Aust. J. Sci. Res. B5:344-353.

Chopard, I. 1924.

Gryllides de Juan-Fernandez et de l'île de Pâques. In. Skottsberg, C. (Ed.). The Natural History of Juan Fernandez and Easter Island. Uppsala. 3:321-323.

Chopard, I. 1951.

A revision of the Australian Grylloidea.

Rec. S. Aust. Mus. 9:410.

*Chopard, L. 1961.

Les divisions du genre Gryllus basees sur I'etude de I'appareil copulateur (Ortho., Gryllidae).

Eos, Madr. 37:267-287.

Cochaux, P. 1964.

Croisements introspecifiques et specification chez quelques gryllides des genres Gryllus et Teleogryllus (Orthoptera: Gryllidae).

Canad. J. Zool. 43:105-124.

*orbel, J. C. 1963.

Caractéres spécifiques du champ dorsal élytral des mâles de quelques Gryllus.

Bull. Biol. Fr. Belg. XCVII:531-550.

*.Jobzhansky, T. 1951.

"Genetics and the Origin of Species". Columbia University Press, New York. 
Hogan, T. T. 1960.

The onset and duration of diapause in eggs of Acheta commodus (Walker) (Orthoptera).

Aust. J. Sci. 13:14-29.

*Huxley, J.S. 1932.

"Probelms of Relative Growth". Dial Press, New York.

Leroy, Y. 1963.

Etude du chant de deux espéces de Grillons et de leur hybrids (Gryllus commodus Walker, Gryllus oceanicus Le Guillou, Orthopterés).

C. R. Acad. Sc. 256:268-270.

Leroy, Y. $1964 a$.

Transmission du paranétre fréquence dans le signal acoustique des hybrides $F_{1}$ et $\mathrm{PX} \mathrm{F}_{I}$, de deux Grillons: Teleogryllus comriodus : Ralker et $\underline{T}$. oceanicus Le Guillou TOrthoptéres, Ensiferes). C.R.Acad. Sc. 259:892-895.

Leroy, Y. 19646 .

La signalisation acoustique chez les gryllides. Ann. Biol. III, (9-10):400-428.

*Masaki, S. 1960.

Thermal relations of diapause in the eggs of certain crickets (Orthoptera: Gryllidae).

Bull. Fac. Agric. Hirosaki Univ. 6:5-20.

*Masaki, S. 1965.

Geographic variation in the intrinsic incubation period: A physiological cline in the Emma field cricket (Orthoptera: Gryilidae: Teleogrylius).

Bull. Fac. Agric. Hirosaki Univ. 11:59-90. 
"Ohmachi, F. and Masaki, S. 1964.

Interspecific crossing and development of hybrids between the Japanese species of Teleogrylius (Orthoptera: Gryllidae). Evol. $18: 405-416$.

"RandeIl, R. L. and Kevan, D. K. McE. 1963.

Research on field and house crickets (Orthoptera: Gryllidae: Gryllinae) at Macdonald College. Ann. Ent. Soc. Que. \$:102-107.

"Randell, R. L. 1964.

The male genitalia in Gryllinae (Orthoptera: Gryllidae) and a tribal revision.

Canad. Ent. 96:1565-1607.

*Snodgrass, R. E. 1935.

"Principles of Insect Morphology".

McGraw-Hill Book Company, New York and London.

Steel, R. G. D. and Torrie, J.H. 1960.

"Principles and Procedures of Statistics". McGraw-Hill Book Company, New York, Toronto and London •

The references marked with an asterisk (*) have been consulted during the present work, but are not cited in the text. 


\section{TABLES}

From I to XII 
TABIE I. RATIO OF LENGTH/WIDTH OF BODY

IN SIX TELEOGRYLLUS STRAINS

\begin{tabular}{lcccc}
\multicolumn{5}{c}{ ANALYSIS OF VARIANCE } \\
\cline { 2 - 5 } \\
SOURCE OF VARIATION & S.S. & df. & M.S. & F-VALUE \\
\hline Total & 4.986 & 119 & & \\
Treatments & 1.460 & 11 & & \\
$\quad$ Strains & 1.092 & 5 & 0.218 & $7.03 * *$ \\
$\quad$ Sexes & 0.089 & 1 & 0.089 & 2.87 \\
$\quad$ Sex X Strain & 0.279 & 5 & 0.056 & 1.81 \\
Replications & 0.432 & 9 & 0.048 & 1.55 \\
\hline Errors & 3.094 & 99 & 0.031 & \\
\hline
\end{tabular}

1. From Steel \& Torrie (1960: 194 - 211).

**: Highly significant, based on 0.01 level. 
TABLE II. COMPARISON OF SAMPLE MEANS OF RATIO OF LENGTH/ WIDTH OF BODY OF SIX TELEOGRYLLUS STRAINS

\begin{tabular}{|c|c|c|c|c|c|c|}
\hline & \multicolumn{6}{|c|}{ Sex } \\
\hline & \multicolumn{3}{|c|}{ Male } & \multicolumn{3}{|c|}{ Female } \\
\hline & $\bar{d}^{I}$ & $s_{\bar{d}}^{2}$ & Calc.val? & $\bar{d}$ & $s_{\bar{d}}$ & Calc.val. \\
\hline$Q a-Q w$ & 0.019 & 0.066 & 0.288 & 0.066 & 0.102 & 0.647 \\
\hline$Q_{a}-Q_{n}$ & 0.132 & 0.052 & $2.538 \%$ & 0.351 & 0.117 & $3.000 * * *$ \\
\hline $2 a-2 k$ & 0.029 & 0.043 & 0.674 & 0.223 & 0.128 & 1.742 \\
\hline$Q a-Q z$ & 0.164 & 0.050 & $3.280 * * *$ & 0.060 & 0.110 & 0.545 \\
\hline $2 a-g c$ & 0.074 & 0.054 & 1.370 & 0.214 & 0.123 & 1.740 \\
\hline$Q W-Q n$ & 0.151 & 0.068 & $2.221 \%$ & 0.285 & 0.076 & $3.750 \%$ \\
\hline$Q W-Q k$ & 0.048 & 0.062 & 0.774 & 0.157 & 0.091 & 1.725 \\
\hline $2 w-2 z$ & 0.145 & 0.067 & $2.164: *$ & 0.006 & 0.065 & 0.092 \\
\hline$Q W-Q C$ & 0.055 & 0.070 & 0.786 & 0.148 & 0.085 & 1.741 \\
\hline$Q n-Q k$ & 0.103 & 0.047 & $2.191 *$ & 0.128 & 0.107 & 1.196 \\
\hline$Q n-Q z$ & 0.296 & 0.053 & $5.585 \% *$ & 0.291 & 0.086 & $3.384 * * *$ \\
\hline$Q n-Q c$ & 0.206 & 0.057 & $3.614 * * *$ & 0.137 & 0.102 & 1.343 \\
\hline$Q k-Q z$ & 0.193 & 0.044 & $4.386 * * *$ & 0.163 & 0.100 & 1.630 \\
\hline$Q k-Q c$ & 0.103 & 0.049 & $2.102 *$ & 0.009 & 0.114 & 0.079 \\
\hline$Q z-Q c$ & 0.090 & 0.055 & 1.636 & 0.154 & 0.094 & 1.638 \\
\hline
\end{tabular}

1. $\overline{\mathrm{d}}$ : difference between two sample means.

2. $S \frac{d}{d}$ : sample standard deviation, calculated by equation: $s_{\bar{d}}=\left(2 s^{2} / n\right)^{\frac{1}{2}}$, where $s^{2}$ obtanied by equation: $s^{2}=$ $\left[\left(n_{1}-1\right) s_{1}^{2}+\left(n_{2}-1\right) s_{2}^{2}\right] /\left[\left(n_{1}-1\right)+\left(n_{2}-1\right)\right]$, $\mathrm{n}=\mathrm{n}_{1}=\mathrm{n}_{2}=10^{\circ}=$ sample size of each strain, assuming $\mu_{I}=\mu_{2}, \sigma_{I}^{2}=\sigma_{2}^{2}$.

3. T-value, calculated by equation: $t=\bar{d} / s_{2}$. *: Significant, based on 0.05 level, $d f=18$. **: Highly significant, based on 0.01 level, $d f=18$. 
TABLE III. RATIO OF LENGTH/IIDTH OF BODY OF SIX TELEOGRYLLUS STRAINS

\begin{tabular}{|c|c|c|c|c|c|c|c|c|}
\hline Strain & Sex & $\begin{array}{l}\text { Specimens } \\
\text { Measured }\end{array}$ & $\bar{x}$ & $s$ & $\begin{array}{l}\text { Range of } \\
\text { Individuals }\end{array}$ & $\frac{s}{x}$ & Range & of Mean ${ }^{1}$ \\
\hline Qa & $\begin{array}{l}\text { Male } \\
\text { Female }\end{array}$ & $\begin{array}{l}10 \\
10\end{array}$ & $\begin{array}{l}3.654 \\
3.877\end{array}$ & $\begin{array}{l}0.106 \\
0.303\end{array}$ & $\begin{array}{l}3.548-3.760 \\
3.574-4.180\end{array}$ & $\begin{array}{l}0.034 \\
0.096\end{array}$ & $\begin{array}{l}3.543 \\
3.565\end{array}$ & $\begin{array}{l}-3.765 \\
-4.189\end{array}$ \\
\hline QW & $\begin{array}{l}\text { Male } \\
\text { Female }\end{array}$ & $\begin{array}{l}10 \\
10\end{array}$ & $\begin{array}{l}3.673 \\
3.811\end{array}$ & $\begin{array}{l}0.178 \\
0.113\end{array}$ & $\begin{array}{l}3.495-3.851 \\
3.698-3.921\end{array}$ & $\begin{array}{l}0.056 \\
0.036\end{array}$ & $\begin{array}{l}3.491 \\
3.694\end{array}$ & $\begin{array}{l}-3.855 \\
-3.928\end{array}$ \\
\hline On & $\begin{array}{l}\text { Male } \\
\text { Female }\end{array}$ & $\begin{array}{l}10 \\
10\end{array}$ & $\begin{array}{l}3.522 \\
3.526\end{array}$ & $\begin{array}{l}0.124 \\
0.212\end{array}$ & $\begin{array}{l}3.398-3.646 \\
3.314-3.738\end{array}$ & $\begin{array}{l}0.039 \\
0.067\end{array}$ & $\begin{array}{l}3.395 \\
3.308\end{array}$ & $\begin{array}{l}-3.649 \\
-3.744\end{array}$ \\
\hline Qk & $\begin{array}{l}\text { Male } \\
\text { Female }\end{array}$ & $\begin{array}{l}10 \\
10\end{array}$ & $\begin{array}{l}3.625 \\
3.654\end{array}$ & $\begin{array}{l}0.083 \\
0.265\end{array}$ & $\begin{array}{l}3.542-3.708 \\
3.389-3.919\end{array}$ & $\begin{array}{l}0.026 \\
0.084\end{array}$ & $\begin{array}{l}3.541 \\
3.381\end{array}$ & $\begin{array}{l}-3.709 \\
-\quad 3.927\end{array}$ \\
\hline$Q z$ & $\begin{array}{l}\text { Male } \\
\text { Female }\end{array}$ & $\begin{array}{l}10 \\
10\end{array}$ & $\begin{array}{l}3.818 \\
3.817\end{array}$ & $\begin{array}{l}0.113 \\
0.170\end{array}$ & $\begin{array}{l}3.705-3.931 \\
3.647-3.987\end{array}$ & $\begin{array}{l}0.036 \\
0.054\end{array}$ & $\begin{array}{l}3.701 \\
3.641\end{array}$ & $\begin{array}{l}-3.935 \\
-3.993\end{array}$ \\
\hline Qc & $\begin{array}{l}\text { Male } \\
\text { Female }\end{array}$ & $\begin{array}{l}10 \\
10\end{array}$ & $\begin{array}{l}3.728 \\
3.663\end{array}$ & $\begin{array}{l}0.133 \\
0.244\end{array}$ & $\begin{array}{l}3.595-3.861 \\
3.419-3.907\end{array}$ & $\begin{array}{l}0.042 \\
0.077\end{array}$ & $\begin{array}{l}3.592 \\
3.413\end{array}$ & $\begin{array}{l}-3.864 \\
-3.913\end{array}$ \\
\hline
\end{tabular}

1. $\mu=\bar{x} \pm t .01 \times S \bar{x}, d f=9$, based on 0.01 level. 
TABLE IV. LENGTH AND VIDTH OF BODY IN SIX TELEOGRYLLUS STRAINS (mm)

\begin{tabular}{|c|c|c|c|c|c|c|}
\hline Strain & Sex & $\begin{array}{l}\text { Specimens } \\
\text { Measured }\end{array}$ & $\begin{array}{l}\text { Mean of } \\
\text { Length }\end{array}$ & $\begin{array}{l}\text { Range of } \\
\text { Measurements }\end{array}$ & $\begin{array}{l}\text { Iean of } \\
\text { Width }\end{array}$ & $\begin{array}{l}\text { Range of } \\
\text { Ileasurements }\end{array}$ \\
\hline Qa & $\begin{array}{l}\text { Male } \\
\text { Female }\end{array}$ & $\begin{array}{l}10 \\
10\end{array}$ & $\begin{array}{l}25.460 \\
24.840\end{array}$ & $\begin{array}{l}24.00=27.10 \\
18.00=27.50\end{array}$ & $\begin{array}{l}6.970 \\
6.400\end{array}$ & $\begin{array}{l}6.50=7.60 \\
5.50=7.00\end{array}$ \\
\hline $\mathrm{QW}$ & $\begin{array}{l}\text { Hale } \\
\text { Female }\end{array}$ & $\begin{array}{l}10 \\
10\end{array}$ & $\begin{array}{l}24.020 \\
23.940\end{array}$ & $\begin{array}{l}23.10=25.00 \\
21.50-26.50\end{array}$ & $\begin{array}{l}6.550 \\
6.290\end{array}$ & $\begin{array}{l}6.00-6.95 \\
5.70=7.00\end{array}$ \\
\hline Qn & $\begin{array}{l}\text { Male } \\
\text { Female }\end{array}$ & $\begin{array}{l}10 \\
10\end{array}$ & $\begin{array}{l}24.240 \\
24.000\end{array}$ & $\begin{array}{l}21.50-26.90 \\
21.50-28.00\end{array}$ & $\begin{array}{l}6.880 \\
6.800\end{array}$ & $\begin{array}{l}6.50=7.50 \\
6.50=7.50\end{array}$ \\
\hline$Q k$ & $\begin{array}{l}\text { Male } \\
\text { Female }\end{array}$ & $\begin{array}{l}10 \\
10\end{array}$ & $\begin{array}{l}24.670 \\
23.770\end{array}$ & $\begin{array}{l}20.50-26.10 \\
20.00=28.50\end{array}$ & $\begin{array}{l}6.800 \\
6.500\end{array}$ & $\begin{array}{l}5.90-7.05 \\
5.80-7.00\end{array}$ \\
\hline $\mathrm{Qz}$ & $\begin{array}{l}\text { Male } \\
\text { Female }\end{array}$ & $\begin{array}{l}10 \\
10\end{array}$ & $\begin{array}{l}24.735 \\
25.080\end{array}$ & $\begin{array}{l}22.10-28.00 \\
23.00-29.00\end{array}$ & $\begin{array}{l}6.480 \\
6.570\end{array}$ & $\begin{array}{l}5.80=7.20 \\
6.00=7.20\end{array}$ \\
\hline$Q C$ & $\begin{array}{l}\text { Male } \\
\text { Female }\end{array}$ & $\begin{array}{l}10 \\
10\end{array}$ & $\begin{array}{l}24.370 \\
22.950\end{array}$ & $\begin{array}{l}19.00-27.50 \\
19.50-27.00\end{array}$ & $\begin{array}{l}6.545 \\
6.260\end{array}$ & $\begin{array}{l}5.10-7.80 \\
5.70=7.00\end{array}$ \\
\hline
\end{tabular}


TABLE V. RATIO OF LENGTH/WIDTH OF FRONS

OF SIX TELEOGRYLLUS STRAINS

\begin{tabular}{lcccc}
\multicolumn{5}{c}{ ANALYSIS OF VARIANCE } \\
SOURCE OF VARIATION & S.S. & df. & M.S. & F-VALUE \\
\hline Total & 0.866 & 119 & & \\
Treatments & 0.604 & 11 & & \\
$\quad$ Strains & 0.465 & 5 & 0.0930 & $37.20 * *$ \\
$\quad$ Sexes & 0.099 & 1 & 0.0990 & $39.60 * *$ \\
$\quad$ Sex X Strain & 0.040 & 5 & 0.0080 & $3.20 * *$ \\
Replications & 0.013 & 9 & 0.0014 & 0.56 \\
\hline Errors & 0.249 & 99 & 0.0025 & \\
\hline
\end{tabular}

1. Refer to foot-note in Table I.

*: Significant, based on 0.05 level.

**ik: Highly significant, based on 0.01 level. 
TABIE VI. COMPARISON OF SAMPLE MEANS OF RATIO OF LENGTH/ WIDTH OF FRONS OF SIX TELEOGRYLLUS STRAINS

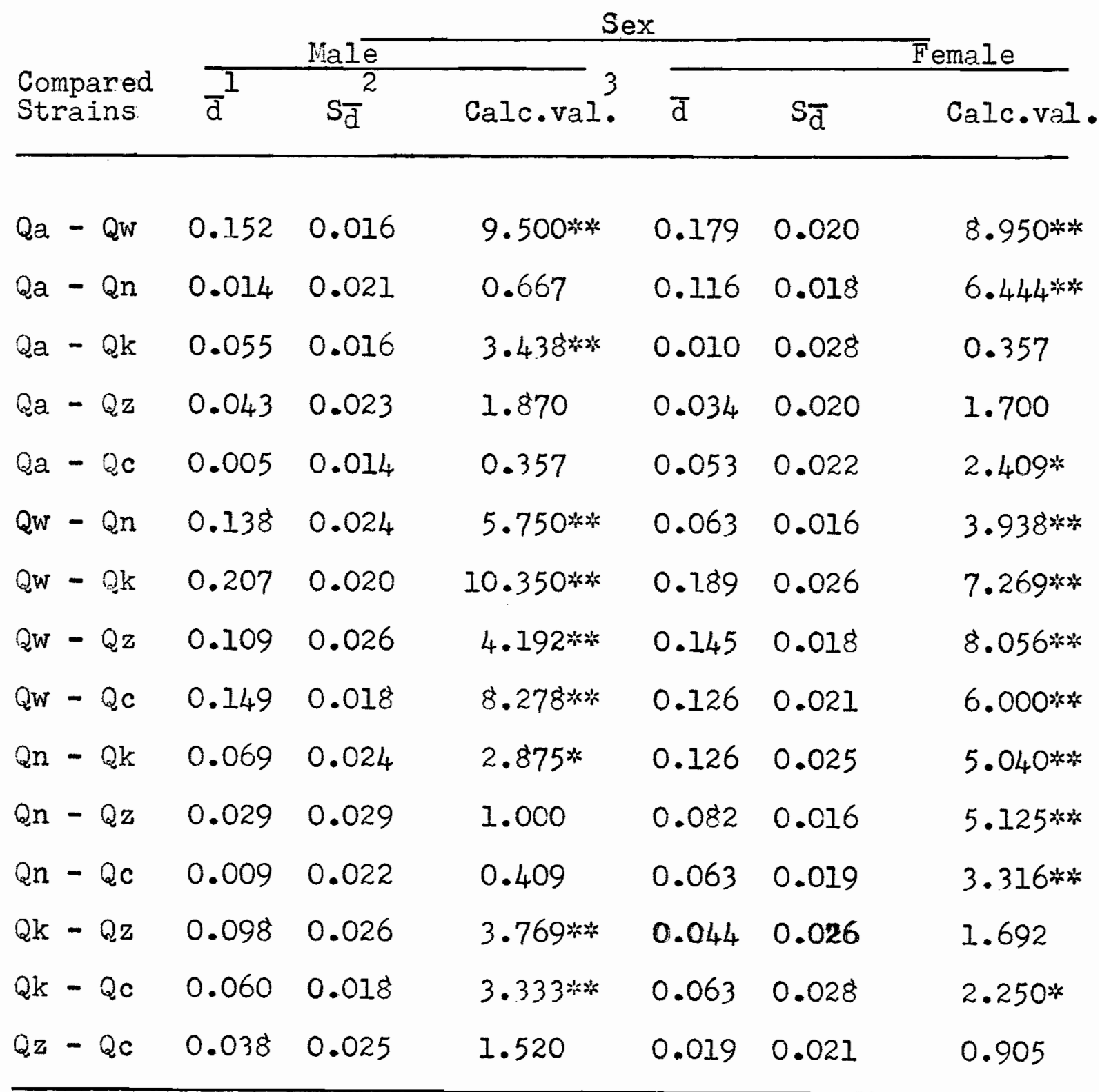

1, 2, and 3 refer to foot-notes in Table II.

*: Significant, based on 0.05 level, df $=18$.

**: Highly significant, based on 0.01 level, $d f=18$. 
TABLE VII. RATIO OF LENGTH/WIDTH OF FRONS OF SIX TELEOGRYLLUS STRAINS

\begin{tabular}{|c|c|c|c|c|c|c|c|c|}
\hline Strain & Sex & $\begin{array}{l}\text { Specimens } \\
\text { Measured }\end{array}$ & $\bar{x}$ & $\underline{s}$ & $\begin{array}{l}\text { Range of } \\
\text { Individuals }\end{array}$ & $S_{\bar{x}}$ & Range & of Mean ${ }^{1}$ \\
\hline $\mathrm{Qa}$ & $\begin{array}{l}\text { Male } \\
\text { Female }\end{array}$ & $\begin{array}{l}10 \\
10\end{array}$ & $\begin{array}{l}1.654 \\
1.632\end{array}$ & $\begin{array}{l}0.026 \\
0.048\end{array}$ & $\begin{array}{l}1.628-1.680 \\
1.584-1.680\end{array}$ & $\begin{array}{l}0.008 \\
0.015\end{array}$ & $\begin{array}{l}1.628 \\
1.538\end{array}$ & $\begin{array}{l}-1.680 \\
-1.681\end{array}$ \\
\hline QW & $\begin{array}{l}\text { Male } \\
\text { Female }\end{array}$ & $\begin{array}{l}10 \\
10\end{array}$ & $\begin{array}{l}1.502 \\
1.453\end{array}$ & $\begin{array}{l}0.044 \\
0.040\end{array}$ & $\begin{array}{l}1.458-1.546 \\
1.413-1.493\end{array}$ & $\begin{array}{l}0.014 \\
0.013\end{array}$ & $\begin{array}{l}1.456 \\
1.411\end{array}$ & $\begin{array}{l}-1.548 \\
-1.495\end{array}$ \\
\hline Qn & $\begin{array}{l}\text { Male } \\
\text { Female }\end{array}$ & $\begin{array}{l}10 \\
10\end{array}$ & $\begin{array}{l}1.640 \\
1.516\end{array}$ & $\begin{array}{l}0.061 \\
0.033\end{array}$ & $\begin{array}{l}1.579-1.701 \\
1.483-1.549\end{array}$ & $\begin{array}{l}0.019 \\
0.010\end{array}$ & $\begin{array}{l}1.578 \\
1.484\end{array}$ & $\begin{array}{l}-1.702 \\
-1.548\end{array}$ \\
\hline$Q k$ & $\begin{array}{l}\text { Male } \\
\text { Female }\end{array}$ & $\begin{array}{l}10 \\
10\end{array}$ & $\begin{array}{l}1.709 \\
1.642\end{array}$ & $\begin{array}{l}0.045 \\
0.074\end{array}$ & $\begin{array}{l}1.664-1.754 \\
1.568-1.716\end{array}$ & $\begin{array}{l}0.014 \\
0.023\end{array}$ & $\begin{array}{l}1.663 \\
1.567\end{array}$ & $\begin{array}{l}-1.755 \\
-1.717\end{array}$ \\
\hline$Q z$ & $\begin{array}{l}\text { Male } \\
\text { Female }\end{array}$ & $\begin{array}{l}10 \\
10\end{array}$ & $\begin{array}{l}1.611 \\
1.598\end{array}$ & $\begin{array}{l}0.068 \\
0.042\end{array}$ & $\begin{array}{l}1.543-1.679 \\
1.556-1.640\end{array}$ & $\begin{array}{l}0.022 \\
0.013\end{array}$ & $\begin{array}{l}1.539 \\
1.556\end{array}$ & $\begin{array}{l}-1.683 \\
-1.640\end{array}$ \\
\hline Qc & $\begin{array}{l}\text { Male } \\
\text { Female }\end{array}$ & $\begin{array}{l}10 \\
10\end{array}$ & $\begin{array}{l}1.649 \\
1.579\end{array}$ & $\begin{array}{l}0.038 \\
0.049\end{array}$ & $\begin{array}{l}1.611-1.687 \\
1.530-1.628\end{array}$ & $\begin{array}{l}0.012 \\
0.016\end{array}$ & $\begin{array}{l}1.610 \\
1.527\end{array}$ & $\begin{array}{l}-1.688 \\
-1.631\end{array}$ \\
\hline
\end{tabular}

1. Refer to foot-note in Table III. 
TABLE VIII. LENGTH AND VIDTH OF FRONS IN SIX TELEOGRYLLUS STRAINS (mm)

\begin{tabular}{|c|c|c|c|c|c|c|}
\hline Strain & Sex & $\begin{array}{l}\text { Specimens } \\
\text { Measured }\end{array}$ & $\begin{array}{l}\text { Mean of } \\
\text { Length }\end{array}$ & $\begin{array}{l}\text { Range of } \\
\text { Measurements }\end{array}$ & $\begin{array}{l}\text { Mean of } \\
\text { Width }\end{array}$ & $\begin{array}{l}\text { Range of } \\
\text { Measurements }\end{array}$ \\
\hline Qa & $\begin{array}{l}\text { Male } \\
\text { Female }\end{array}$ & $\begin{array}{l}10 \\
10\end{array}$ & $\begin{array}{l}2.580 \\
2.440\end{array}$ & $\begin{array}{l}2.300-2.850 \\
2.300=2.700\end{array}$ & $\begin{array}{l}1.560 \\
1.495\end{array}$ & $\begin{array}{l}1.400-1.700 \\
1.400-1.650\end{array}$ \\
\hline$Q W$ & $\begin{array}{l}\text { Male } \\
\text { Female }\end{array}$ & $\begin{array}{l}10 \\
10\end{array}$ & $\begin{array}{l}2.370 \\
2.180\end{array}$ & $\begin{array}{l}2.200-2.500 \\
2.000-2.400\end{array}$ & $\begin{array}{l}1.580 \\
1.500\end{array}$ & $\begin{array}{l}1.450=1.700 \\
1.400=1.650\end{array}$ \\
\hline$\partial n$ & $\begin{array}{l}\text { Niale } \\
\text { Female }\end{array}$ & $\begin{array}{l}10 \\
10\end{array}$ & $\begin{array}{l}2.595 \\
2.380\end{array}$ & $\begin{array}{l}2.300-2.900 \\
2.250-2.500\end{array}$ & $\begin{array}{l}1.580 \\
1.570\end{array}$ & $\begin{array}{l}1.450-1.700 \\
1.500-1.650\end{array}$ \\
\hline Qk & $\begin{array}{l}\text { Male } \\
\text { Female }\end{array}$ & $\begin{array}{l}10 \\
10\end{array}$ & $\begin{array}{l}2.565 \\
2.475\end{array}$ & $\begin{array}{l}2.350-2.750 \\
2.200-2.700\end{array}$ & $\begin{array}{l}1.500 \\
1.510\end{array}$ & $\begin{array}{l}1.400=1.600 \\
1.350-1.700\end{array}$ \\
\hline$Q z$ & $\begin{array}{l}\text { Male } \\
\text { Female }\end{array}$ & $\begin{array}{l}10 \\
10\end{array}$ & $\begin{array}{l}2.310 \\
2.285\end{array}$ & $\begin{array}{l}2.100-2.650 \\
2.150-2.650\end{array}$ & $\begin{array}{l}1.435 \\
1.430\end{array}$ & $\begin{array}{l}1.300-1.600 \\
1.350-1.650\end{array}$ \\
\hline$Q C$ & $\begin{array}{l}\text { Male } \\
\text { Female }\end{array}$ & $\begin{array}{l}10 \\
10\end{array}$ & $\begin{array}{l}2.450 \\
2.345\end{array}$ & $\begin{array}{l}2.150-2.650 \\
2.150-2.600\end{array}$ & $\begin{array}{l}1.485 \\
1.485\end{array}$ & $\begin{array}{l}1.350-1.600 \\
1.400-1.600\end{array}$ \\
\hline
\end{tabular}


TABLE IX. RATIO OF WIDTH/LENGTH OF PRONOTUM
OF SIX

ANALYSIS OF VARIANCE ${ }^{1}$

\begin{tabular}{lrrrr} 
SOURCE OF VARIATION & S.S. & df. & M.S. & F-VALUE \\
\hline Total & 1.746 & 119 & & \\
Treatments & 0.976 & 11 & & \\
$\quad$ Strains & 0.550 & 5 & 0.1100 & $15.94 * *$ \\
$\quad$ Sexes & 0.367 & 1 & 0.3670 & $53.19 * *$ \\
$\quad$ Sex X Strain & 0.059 & 5 & 0.0118 & 1.71 \\
Replications & 0.086 & 9 & 0.0096 & 1.39 \\
\hline Errors & 0.684 & 99 & 0.0069 & \\
\hline
\end{tabular}

1. Refer to foot-note in Table I.

**: Highly significant, based on 0.01 level. 
TABLE $X$. COMPARISON OF SAMPLE MEANS OF RATIO OF WIDTH/ LENGTH OF PRONOTUI OF SIX TELEOGRYLLUS STRAINS

\begin{tabular}{|c|c|c|c|c|c|c|}
\hline \multirow[b]{2}{*}{$\begin{array}{l}\text { Compared } \\
\text { Strains }\end{array}$} & & \multicolumn{3}{|c|}{ Female } \\
\hline & $\overline{\mathrm{d}}$ & $s_{\bar{d}}^{2}$ & Calc.val. & $\bar{d}$ & $s_{\bar{d}}$ & Calc.val \\
\hline$Q a-Q w$ & 0.093 & 0.030 & $3.100 * * *$ & 0.087 & 0.027 & $3.222 * *$ \\
\hline$Q a-Q n$ & 0.177 & 0.038 & $4.658 \%$ & 0.093 & 0.035 & $2.657^{\prime}$ \\
\hline$Q a-Q k$ & 0.059 & 0.039 & 1.513 & 0.029 & 0.029 & 1.000 \\
\hline$Q a-2 z$ & 0.042 & 0.032 & 1.312 & 0.072 & 0.033 & $2.182 *$ \\
\hline $2 a-Q c$ & 0.008 & 0.048 & 0.167 & 0.002 & 0.032 & 0.062 \\
\hline $2 w-Q n$ & 0.270 & 0.041 & $6.585 \%$ & 0.180 & 0.030 & $6.000 * *$ \\
\hline$Q W-Q k$ & 0.152 & 0.042 & $3.619 * * *$ & 0.116 & 0.022 & $5.273 * * *$ \\
\hline$Q w-Q z$ & 0.135 & 0.035 & $3.857 \%$ & 0.015 & 0.028 & 0.536 \\
\hline$Q W-Q c$ & 0.101 & 0.050 & 2.020 & 0.085 & 0.026 & $3.269 \% *$ \\
\hline$Q n-Q k$ & 0.118 & 0.048 & $2.458 \%$ & 0.064 & 0.031 & 2.064 \\
\hline$Q n-Q z$ & 0.135 & 0.042 & $3.214 \%$ & 0.165 & 0.035 & $4.714^{*} * 2 *$ \\
\hline$Q n-Q c$ & 0.169 & 0.055 & $3.073 * * * *$ & 0.095 & 0.034 & $2.794 *$ \\
\hline$Q k-Q z$ & 0.017 & 0.044 & 0.386 & 0.101 & 0.029 & $3.607 *$ \\
\hline$Q k-Q c$ & 0.051 & 0.056 & 0.911 & 0.031 & 0.028 & 1.107 \\
\hline$Q z-Q c$ & 0.034 & 0.051 & 0.667 & 0.070 & 0.033 & $2.121 *$ \\
\hline
\end{tabular}

1, 2, and 3 refer to foot-notes in Table II.

*: Significant, based on 0.05 level, df $=18$.

**: Highly significant, based on 0.01 level, $d f=18$. 
TABLE XI. RATIO OF WIDTH/LENGTH OF PRONOTUM OF SIX TELEOGRYLLUS STRAINS

\begin{tabular}{|c|c|c|c|c|c|c|c|c|}
\hline Strain & Sex & $\begin{array}{l}\text { Specimens } \\
\text { lieasured } \\
\end{array}$ & $\bar{x}$ & $s$ & $\begin{array}{l}\text { Range of } \\
\text { Individuals } \\
\end{array}$ & $\frac{S}{x}$ & Range & of $\operatorname{Mean}^{1}$ \\
\hline Qa & $\begin{array}{l}\text { Male } \\
\text { Female }\end{array}$ & $\begin{array}{l}10 \\
10\end{array}$ & $\begin{array}{l}2.964 \\
2.892\end{array}$ & $\begin{array}{l}0.057 \\
0.072\end{array}$ & $\begin{array}{l}2.907-3.021 \\
2.820-2.964\end{array}$ & $\begin{array}{l}0.018 \\
0.023\end{array}$ & $\begin{array}{l}2.906 \\
2.817\end{array}$ & $\begin{array}{l}-3.022 \\
-2.967\end{array}$ \\
\hline QTw & $\begin{array}{l}\text { Miale } \\
\text { Female }\end{array}$ & $\begin{array}{l}10 \\
10\end{array}$ & $\begin{array}{l}2.871 \\
2.805\end{array}$ & $\begin{array}{l}0.075 \\
0.045\end{array}$ & $\begin{array}{l}2.796-2.946 \\
2.760-2.850\end{array}$ & $\begin{array}{l}0.024 \\
0.014\end{array}$ & $\begin{array}{l}2.793 \\
2.759\end{array}$ & $\begin{array}{l}-2.949 \\
-2.851\end{array}$ \\
\hline Qn & $\begin{array}{l}\text { Male } \\
\text { Female }\end{array}$ & $\begin{array}{l}10 \\
10\end{array}$ & $\begin{array}{l}3.141 \\
2.985\end{array}$ & $\begin{array}{l}0.105 \\
0.082\end{array}$ & $\begin{array}{l}3.036-3.246 \\
2.903-3.067\end{array}$ & $\begin{array}{l}0.033 \\
0.026\end{array}$ & $\begin{array}{l}3.034 \\
2.901\end{array}$ & $\begin{array}{l}-3.248 \\
-3.069\end{array}$ \\
\hline$Q k$ & $\begin{array}{l}\text { Male } \\
\text { Female }\end{array}$ & $\begin{array}{l}10 \\
10\end{array}$ & $\begin{array}{l}3.023 \\
2.921\end{array}$ & $\begin{array}{l}0.110 \\
0.053\end{array}$ & $\begin{array}{l}2.913-3.133 \\
2.868-2.974\end{array}$ & $\begin{array}{l}0.035 \\
0.017\end{array}$ & $\begin{array}{l}2.909 \\
2.866\end{array}$ & $\begin{array}{l}-3.137 \\
-2.976\end{array}$ \\
\hline $\mathrm{Qz}$ & $\begin{array}{l}\text { Male } \\
\text { Female }\end{array}$ & $\begin{array}{l}10 \\
10\end{array}$ & $\begin{array}{l}3.006 \\
2.820\end{array}$ & $\begin{array}{l}0.082 \\
0.077\end{array}$ & $\begin{array}{l}2.924-3.088 \\
2.743-2.897\end{array}$ & $\begin{array}{l}0.026 \\
0.024\end{array}$ & $\begin{array}{l}2.922 \\
2.742\end{array}$ & $\begin{array}{l}-3.090 \\
-2.898\end{array}$ \\
\hline$Q C$ & $\begin{array}{l}\text { Wale } \\
\text { Female }\end{array}$ & $\begin{array}{l}10 \\
10\end{array}$ & $\begin{array}{l}2.972 \\
2.890\end{array}$ & $\begin{array}{l}0.138 \\
0.071\end{array}$ & $\begin{array}{l}2.834-3.110 \\
2.819-2.961\end{array}$ & $\begin{array}{l}0.044 \\
0.022\end{array}$ & $\begin{array}{l}2.829 \\
2.818\end{array}$ & $\begin{array}{l}-3.115 \\
-2.962\end{array}$ \\
\hline
\end{tabular}

1. Refer to foot-note in Table III. 
TABLE XII. WIDTH AND LENGTH OF PRONOTUM IN SIX EELEOGRYLLUS STRAINS (mm)

\begin{tabular}{|c|c|c|c|c|c|c|}
\hline Strain & Sex & $\begin{array}{l}\text { Specimens } \\
\text { Mieasured }\end{array}$ & $\begin{array}{l}\text { Mean of } \\
\text { Vidth }\end{array}$ & $\begin{array}{l}\text { Range of } \\
\text { Measurements }\end{array}$ & $\begin{array}{l}\text { INean of } \\
\text { Length }\end{array}$ & $\begin{array}{l}\text { Range of } \\
\text { Measurements }\end{array}$ \\
\hline Qa & $\begin{array}{l}\text { Male } \\
\text { Female }\end{array}$ & $\begin{array}{l}10 \\
10\end{array}$ & $\begin{array}{l}11.160 \\
10.970\end{array}$ & $\begin{array}{l}9.500-12.300 \\
9.800-12.500\end{array}$ & $\begin{array}{l}3.765 \\
3.795\end{array}$ & $\begin{array}{l}3.250-4.150 \\
3.500-4.400\end{array}$ \\
\hline QW & $\begin{array}{l}\text { Tale } \\
\text { Female }\end{array}$ & $\begin{array}{l}10 \\
10\end{array}$ & $\begin{array}{l}10.350 \\
10.310\end{array}$ & $\begin{array}{l}9.300=11.600 \\
8.900=11.200\end{array}$ & $\begin{array}{l}3.605 \\
3.675\end{array}$ & $\begin{array}{l}3.250-4.000 \\
3.150-3.950\end{array}$ \\
\hline Qn & $\begin{array}{l}\text { Male } \\
\text { Female }\end{array}$ & $\begin{array}{l}10 \\
10\end{array}$ & $\begin{array}{l}11.090 \\
11.240\end{array}$ & $\begin{array}{l}10.300=12.200 \\
10.500=11.900\end{array}$ & $\begin{array}{l}3.535 \\
3.750\end{array}$ & $\begin{array}{l}3.300=4.100 \\
3.550-4.050\end{array}$ \\
\hline Qk & $\begin{array}{l}\text { Male } \\
\text { Female }\end{array}$ & $\begin{array}{l}10 \\
10\end{array}$ & $\begin{array}{l}10.970 \\
11.000\end{array}$ & $\begin{array}{r}10.000-12.000 \\
9.400=11.800\end{array}$ & $\begin{array}{l}3.630 \\
3.765\end{array}$ & $\begin{array}{l}3.400-3.800 \\
3.300-4.050\end{array}$ \\
\hline$Q z$ & $\begin{array}{l}\text { Male } \\
\text { Female }\end{array}$ & $\begin{array}{l}10 \\
10\end{array}$ & $\begin{array}{r}10.680 \\
9.785\end{array}$ & $\begin{array}{r}10.000-12.500 \\
9.000-11.600\end{array}$ & $\begin{array}{l}3.555 \\
3.470\end{array}$ & $\begin{array}{l}3.300-4.150 \\
3.250-4.000\end{array}$ \\
\hline$Q c$ & $\begin{array}{l}\text { Male } \\
\text { Female }\end{array}$ & $\begin{array}{l}10 \\
10\end{array}$ & $\begin{array}{l}10.670 \\
10.300\end{array}$ & $\begin{array}{l}9.600-12.300 \\
9.500-11.900\end{array}$ & $\begin{array}{l}3.590 \\
3.565\end{array}$ & $\begin{array}{l}3.200-3.850 \\
3.350-4.200\end{array}$ \\
\hline
\end{tabular}


TABLE XIII. NUMBER OF PEGS ON STRIDULATORY VEINS OF SIX TELEOGRYLLUS STRAINS

\section{ANALYSIS OF VARIANCE ${ }^{1}$}

\begin{tabular}{lrrrr} 
SOURCE OF VARIATION & \multicolumn{1}{c}{ S.S. } & df. & M.S. & F-VALUE \\
\hline Total & $125,266.00$ & 119 & & \\
Treatments & $112,356.10$ & 11 & & \\
$\quad$ Strains & $111,774.80$ & 5 & $22,354.96$ & $217.04 * *$ \\
$\quad$ Tegmina & 452.00 & 1 & 452.00 & $4.38 *$ \\
$\quad$ Tegmen X Straun & 129.30 & 5 & 25.86 & 0.25 \\
Replications & $2,712.90$ & 9 & 301.43 & $2.93 * *$ \\
\hline Errors & $10,197.00$ & 99 & 103.00 & \\
\hline
\end{tabular}

1. Refer to foot-note in Table I.

*: Significant, based on 0.05 level.

***: Highly significant, based on 0.01 level. 
TABLE XIV. COMPARISON OF SAMPLE MEANS OF NUMBER OF PEGS ON STRIDULATORY VEINS OF SIX TELEOGRYLLUS STRAINS

Compared Strains

$\frac{\text { Righ }}{\bar{d}^{I}}$

Tegmen

$\bar{d}^{2}$

Calc.val.

$\bar{d}$

$\mathrm{d}_{\overline{\mathrm{d}}}$
Left

Calc.val.

$\begin{array}{lrlcrlc}Q a-Q w & 1.300 & 3.066 & 0.424 & 3.000 & 3.550 & 0.845 \\ Q a-Q n & 79.000 & 5.701 & 13.857 * * & 75.100 & 6.648 & 11.297 * * \\ Q a-Q k & 3.500 & 5.187 & 0.675 & 6.300 & 4.648 & 1.355 \\ Q a-Q z & 4.400 & 3.728 & 1.180 & 11.100 & 4.074 & 2.725 * \\ Q a-Q c & 6.600 & 3.701 & 1.783 & 8.800 & 4.012 & 2.193 * \\ Q w-Q n & 80.300 & 5.441 & 14.758 * * & 78.100 & 6.086 & 12.833 * * \\ Q w-Q k & 2.200 & 4.899 & 0.449 & 3.300 & 3.795 & 0.870 \\ Q w-Q z & 3.100 & 3.178 & 0.975 & 8.100 & 3.073 & 2.636 * \\ Q w-Q c & 5.300 & 3.286 & 1.613 & 5.800 & 2.990 & 1.940 \\ Q n-Q k & 82.500 & 6.856 & 12.033 * * & 81.400 & 6.784 & 11.999 * * \\ Q n-Q z & 83.400 & 5.831 & 14.303 * * & 86.200 & 6.406 & 13.456 * * \\ Q n-Q c & 85.600 & 5.822 & 14.703 * * & 83.900 & 6.367 & 13.177 * * * \\ Q k-Q z & 0.900 & 5.329 & 0.169 & 4.800 & 4.290 & 1.119 \\ Q k-Q c & 3.100 & 5.310 & 0.584 & 2.500 & 4.231 & 0.591 \\ Q z-Q c & 2.200 & 3.912 & 0.562 & 2.300 & 3.592 & 0.640\end{array}$

1, 2, and 3 refer to foot-notes in Table II.

*: Significant, based on 0.05 level, $d f=18$. **: Highly significant, based on 0.01 level, $\mathrm{df}=18$. 
TABLE XV. NUTHER OF PEGS ON STRIDULATORY VEINS

OF SIX TELEOGRYLLUS STRAINS (NLALS)

\begin{tabular}{|c|c|c|c|c|c|c|c|}
\hline Strain & Tegmen & $\begin{array}{l}\text { Specimens } \\
\text { Measured }\end{array}$ & $\bar{x}$ & $\underline{s}$ & $\begin{array}{l}\text { Range of } \\
\text { Individuals }\end{array}$ & $s_{\bar{x}}$ & Range of Mean ${ }^{1}$ \\
\hline $\mathrm{Qa}$ & $\begin{array}{l}\text { Right } \\
\text { Left }\end{array}$ & $\begin{array}{l}10 \\
10\end{array}$ & $\begin{array}{l}178.5 \\
177.5\end{array}$ & $\begin{array}{l}7.849 \\
9.945\end{array}$ & $\begin{array}{l}170.7-186.3 \\
167.6-187.4\end{array}$ & $\begin{array}{l}2.482 \\
3.145\end{array}$ & $\begin{array}{l}170.4=186.6 \\
167.3-187.7\end{array}$ \\
\hline $2 w$ & $\begin{array}{l}\text { Right } \\
\text { Left }\end{array}$ & $\begin{array}{l}10 \\
10\end{array}$ & $\begin{array}{l}177.2 \\
174.5\end{array}$ & $\begin{array}{l}5.831 \\
5.215\end{array}$ & $\begin{array}{l}171.4=183.0 \\
169.3-179.7\end{array}$ & $\begin{array}{l}1.800 \\
1.649\end{array}$ & $\begin{array}{l}171.4=183.0 \\
169.1-179.9\end{array}$ \\
\hline Qn & $\begin{array}{l}\text { Right } \\
\text { Left }\end{array}$ & $\begin{array}{l}10 \\
10\end{array}$ & $\begin{array}{l}257.5 \\
252.6\end{array}$ & $\begin{array}{l}16.220 \\
18.524\end{array}$ & $\begin{array}{l}241.3-273.7 \\
234.1-271.1\end{array}$ & $\begin{array}{l}5.130 \\
5.858\end{array}$ & $\begin{array}{l}240.8-274.2 \\
233.6-271.6\end{array}$ \\
\hline Qk & $\begin{array}{l}\text { Right } \\
\text { Left }\end{array}$ & $\begin{array}{l}10 \\
10\end{array}$ & $\begin{array}{l}175.0 \\
171.2\end{array}$ & $\begin{array}{l}14.390 \\
10.820\end{array}$ & $\begin{array}{l}160.6-189.4 \\
160.4-182.0\end{array}$ & $\begin{array}{l}4.551 \\
3.422\end{array}$ & $\begin{array}{l}160.2-189.8 \\
160.1-182.3\end{array}$ \\
\hline $\mathrm{Qz}$ & $\begin{array}{l}\text { Right } \\
\text { Left }\end{array}$ & $\begin{array}{l}10 \\
10\end{array}$ & $\begin{array}{l}174.1 \\
166.4\end{array}$ & $\begin{array}{l}8.786 \\
8.198\end{array}$ & $\begin{array}{l}165.3-182.9 \\
158.2-174.6\end{array}$ & $\begin{array}{l}2.779 \\
2.593\end{array}$ & $\begin{array}{l}165.1-183.1 \\
158.0-174.8\end{array}$ \\
\hline Qc & $\begin{array}{l}\text { Right } \\
\text { Left }\end{array}$ & $\begin{array}{l}10 \\
10\end{array}$ & $\begin{array}{l}171.9 \\
168.7\end{array}$ & $\begin{array}{l}8.683 \\
7.887\end{array}$ & $\begin{array}{l}163.2-180.6 \\
160.8-176.6\end{array}$ & $\begin{array}{l}2.746 \\
2.494\end{array}$ & $\begin{array}{l}163.0-180.8 \\
160.6-176.8\end{array}$ \\
\hline
\end{tabular}

1. Refer to foot-note in Table III.

2. Both tegmina were calculated from same individual. 
TABLE XVI RATIO OF TIBIA/FEMUR OF

SIX TELEOGRYLLUS STRA INS

\section{ANALYSIS OF VARIANCE ${ }^{1}$}

\begin{tabular}{lcccc} 
SOURCE OF VARIATION & S.S. & df. & M.S. & F-VALUE \\
Total & 0.181 & 239 & & \\
Treatments & 0.055 & 23 & & \\
$\quad$ Strains & 0.047 & 5 & 0.0094 & $15.67 * *$ \\
$\quad$ Sexes & 0.000 & 1 & 0.0000 & 0.00 \\
$\quad$ Sides & 0.000 & 1 & 0.0000 & 0.00 \\
$\quad$ Sex X Strain & 0.005 & 5 & 0.0010 & 1.67 \\
$\quad$ Sex X Side & 0.001 & 1 & 0.0010 & 1.67 \\
$\quad$ Side X Strain & 0.001 & 5 & 0.0002 & 0.33 \\
$\quad$ Sex X Side X & 0.001 & 5 & 0.0002 & 0.33 \\
$\quad$ Strain & & & & \\
Replications & 0.006 & 9 & 0.0007 & 1.17 \\
\hline Errors & 0.120 & 207 & 0.0006 & \\
\hline
\end{tabular}

1. Refer to foot-note in Table I.

**: Highly significant, based on 0.01 level. 
TABLE XVII. COMPARISON OF SAMPLE MEANS OF RATIO OF TIBIA/FEMUR OF SIX TELEOGRYLLUS STRAINS (AN AVERAGE OF TWO SIDES OF FORE-LEGS)

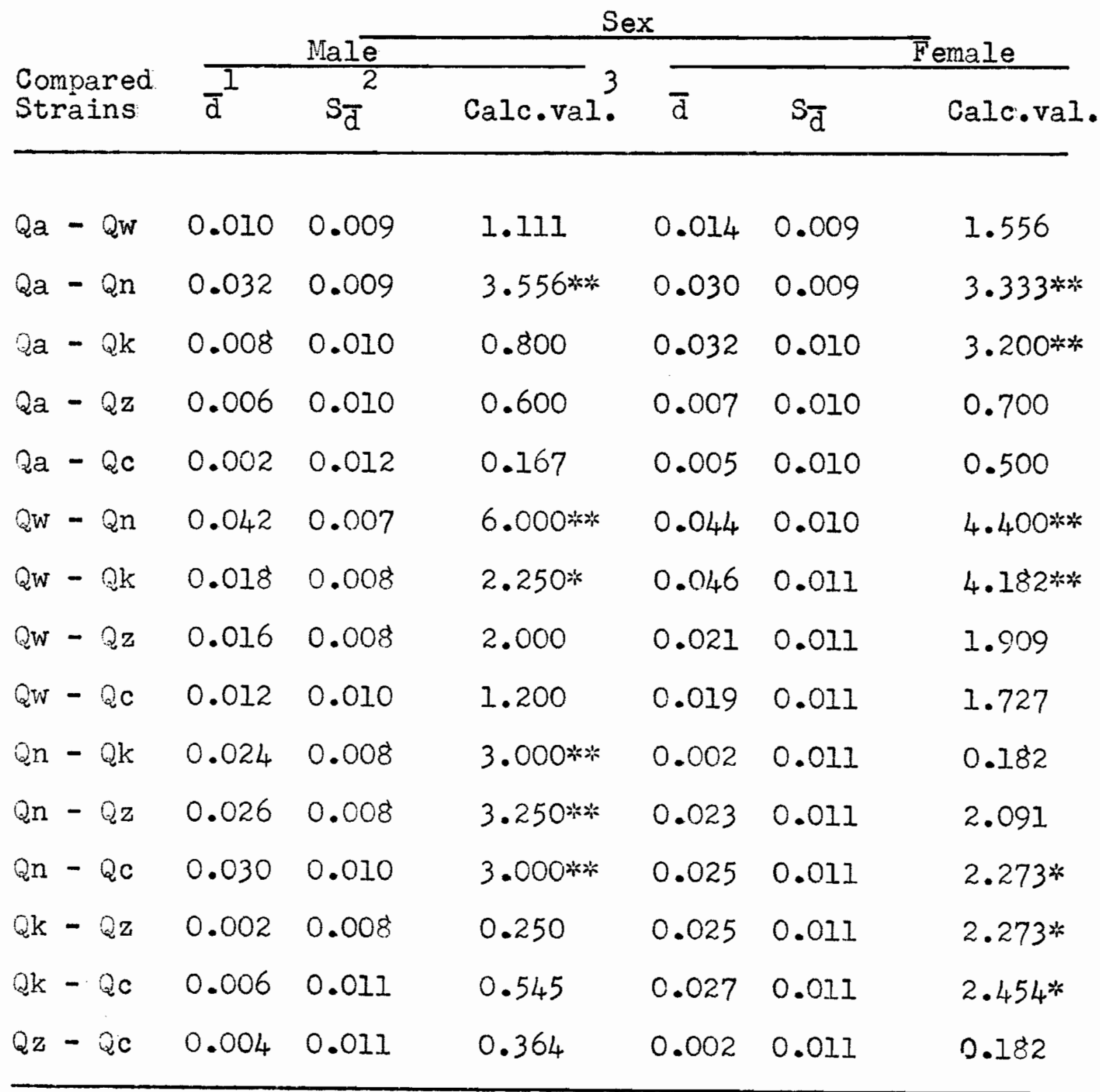

1, 2, and 3 refer to foot-notes in Table II.

*: Significant, based on 0.05 level, df $=18$. **: Highly significant, based on 0.01 level, df $=18$. 
TABIE XVIII. RATIO OF TIBIA/FEMUR OF SIX TELEOGRYLLUS STRAINS

\begin{tabular}{|c|c|c|c|c|c|c|c|c|}
\hline Strain & Sex & $\begin{array}{l}\text { Specimens } \\
\text { Measured }\end{array}$ & $\bar{x}^{2}$ & $s$ & $\begin{array}{l}\text { Range of } \\
\text { Individuals }\end{array}$ & $S \frac{1}{x}$ & Range & of Mean ${ }^{1}$ \\
\hline Qa & $\begin{array}{l}\text { Male } \\
\text { Female }\end{array}$ & $\begin{array}{l}10 \\
10\end{array}$ & $\begin{array}{l}1.006 \\
1.007\end{array}$ & $\begin{array}{l}0.026 \\
0.018\end{array}$ & $\begin{array}{l}0.980-1.032 \\
0.989-1.025\end{array}$ & $\begin{array}{l}0.008 \\
0.006\end{array}$ & $\begin{array}{l}0.980 \\
0.987\end{array}$ & $\begin{array}{l}-1.032 \\
-1.027\end{array}$ \\
\hline$Q W$ & $\begin{array}{l}\text { Male } \\
\text { Female }\end{array}$ & $\begin{array}{l}10 \\
10\end{array}$ & $\begin{array}{l}1.016 \\
1.021\end{array}$ & $\begin{array}{l}0.015 \\
0.021\end{array}$ & $\begin{array}{l}1.001-1.031 \\
1.000-1.042\end{array}$ & $\begin{array}{l}0.005 \\
0.007\end{array}$ & $\begin{array}{l}1.000 \\
0.998\end{array}$ & $\begin{array}{l}-1.032 \\
-1.044\end{array}$ \\
\hline Qn & $\begin{array}{l}\text { Male } \\
\text { Female }\end{array}$ & $\begin{array}{l}10 \\
10\end{array}$ & $\begin{array}{l}0.974 \\
0.977\end{array}$ & $\begin{array}{l}0.015 \\
0.021\end{array}$ & $\begin{array}{l}0.959-0.989 \\
0.956-0.998\end{array}$ & $\begin{array}{l}0.005 \\
0.007\end{array}$ & $\begin{array}{l}0.958 \\
0.954\end{array}$ & $\begin{array}{l}-0.990 \\
-1.000\end{array}$ \\
\hline Qk & $\begin{array}{l}\text { Male } \\
\text { Female }\end{array}$ & $\begin{array}{l}10 \\
10\end{array}$ & $\begin{array}{l}0.998 \\
0.975\end{array}$ & $\begin{array}{l}0.018 \\
0.026\end{array}$ & $\begin{array}{l}0.980-1.016 \\
0.949-1.001\end{array}$ & $\begin{array}{l}0.006 \\
0.008\end{array}$ & $\begin{array}{l}0.978 \\
0.949\end{array}$ & $\begin{array}{l}-1.018 \\
-1.001\end{array}$ \\
\hline$Q z$ & $\begin{array}{l}\text { Male } \\
\text { Female }\end{array}$ & $\begin{array}{l}10 \\
10\end{array}$ & $\begin{array}{l}1.000 \\
1.000\end{array}$ & $\begin{array}{l}0.013 \\
0.026\end{array}$ & $\begin{array}{l}0.982-1.018 \\
0.974-1.026\end{array}$ & $\begin{array}{l}0.006 \\
0.008\end{array}$ & $\begin{array}{l}0.980 \\
0.974\end{array}$ & $\begin{array}{l}-1.020 \\
-1.026\end{array}$ \\
\hline QC & $\begin{array}{l}\text { Male } \\
\text { Female }\end{array}$ & $\begin{array}{l}10 \\
10\end{array}$ & $\begin{array}{l}1.004 \\
1.002\end{array}$ & $\begin{array}{l}0.028 \\
0.024\end{array}$ & $\begin{array}{l}0.976-1.032 \\
0.978-1.026\end{array}$ & $\begin{array}{l}0.009 \\
0.008\end{array}$ & $\begin{array}{l}0.975 \\
0.976\end{array}$ & $\begin{array}{l}-1.033 \\
-1.028\end{array}$ \\
\hline
\end{tabular}

1. Refer to foot-note in Table III.

2. $\bar{x}$ is an average of both fore-legs. 
TABLE XIX. LENGTH OF TIBIA AND FEMUR OF FORE-LEG IN SIX TELEOGRYLLUS STRAINS (mm)

\begin{tabular}{|c|c|c|c|c|c|c|}
\hline Strain & Sex & $\begin{array}{l}\text { Specimens } \\
\text { Iieasured }\end{array}$ & $\begin{array}{l}\text { Mean of } \\
\text { Tibia }\end{array}$ & $\begin{array}{l}\text { Range of } \\
\text { Measurements }\end{array}$ & $\begin{array}{l}\text { Mean of } \\
\text { Femur }\end{array}$ & $\begin{array}{l}\text { Range of } \\
\text { Measurements }\end{array}$ \\
\hline Qa & $\begin{array}{l}\text { Male } \\
\text { Female }\end{array}$ & $\begin{array}{l}10 \\
10\end{array}$ & $\begin{array}{l}4.425 \\
4.312\end{array}$ & $\begin{array}{l}4.000-4.800 \\
4.100=4.450\end{array}$ & $\begin{array}{l}4.398 \\
4.290\end{array}$ & $\begin{array}{l}3.850-4.750 \\
4.100-4.500\end{array}$ \\
\hline $\mathrm{QW}$ & $\begin{array}{l}\text { Male } \\
\text { Female }\end{array}$ & $\begin{array}{l}10 \\
10\end{array}$ & $\begin{array}{l}4 \cdot 432 \\
4.382\end{array}$ & $\begin{array}{l}4.000-4.750 \\
4.050-4.750\end{array}$ & $\begin{array}{l}4.358 \\
4.292\end{array}$ & $\begin{array}{l}3.950-4.700 \\
4.050-4.550\end{array}$ \\
\hline Qn & $\begin{array}{l}\text { Male } \\
\text { Female }\end{array}$ & $\begin{array}{l}10 \\
10\end{array}$ & $\begin{array}{l}4.330 \\
4.128\end{array}$ & $\begin{array}{l}3.750=5.150 \\
3.800=4.450\end{array}$ & $\begin{array}{l}4.450 \\
4.225\end{array}$ & $\begin{array}{l}3.950=5.150 \\
4.000=4.450\end{array}$ \\
\hline$Q k$ & $\begin{array}{l}\text { Male } \\
\text { Female }\end{array}$ & $\begin{array}{l}10 \\
10\end{array}$ & $\begin{array}{l}4.180 \\
4.008\end{array}$ & $\begin{array}{l}3.650-4.700 \\
3.500-4.300\end{array}$ & $\begin{array}{l}4.185 \\
4.110\end{array}$ & $\begin{array}{l}3.750-4.650 \\
3.650-4.550\end{array}$ \\
\hline$Q z$ & $\begin{array}{l}\text { Male } \\
\text { Female }\end{array}$ & $\begin{array}{l}10 \\
10\end{array}$ & $\begin{array}{l}4.042 \\
3.915\end{array}$ & $\begin{array}{l}3.800=4.300 \\
3.650=4.400\end{array}$ & $\begin{array}{l}4.038 \\
3.920\end{array}$ & $\begin{array}{l}3.850-4.200 \\
3.650-4.450\end{array}$ \\
\hline Qc & $\begin{array}{l}\text { Male } \\
\text { Female }\end{array}$ & $\begin{array}{l}10 \\
10\end{array}$ & $\begin{array}{l}4.268 \\
4.170\end{array}$ & $\begin{array}{l}3.850=4.650 \\
3.800=4.650\end{array}$ & $\begin{array}{l}4.252 \\
4.165\end{array}$ & $\begin{array}{l}4.000-4.550 \\
3.850-4.650\end{array}$ \\
\hline
\end{tabular}


TABIE XX. RATIO OF LONGITUDINAL/TRANSVERSE DIAMETER OF TYMPANA OF SIX TELEOGRYLLUS STRAINS

\begin{tabular}{lcccc}
\multicolumn{5}{c}{ ANALYSIS OF VARIANCE } \\
SOURCE OF VARIATION & S.S. & df. & M.S. & F-VALUE \\
\hline Total & 14.681 & 239 & & \\
Treatments & 6.531 & 23 & & \\
$\quad$ Strains & 5.677 & 5 & 1.135 & $30.68 * *$ \\
Sexes & 0.377 & 1 & 0.377 & $10.19 * * *$ \\
$\quad$ Sides & 0.004 & 1 & 0.004 & 0.11 \\
$\quad$ Sex X Strain & 0.272 & 5 & 0.054 & 1.46 \\
$\quad$ Sex X Side & 0.000 & 1 & 0.000 & 0.00 \\
$\quad$ Side X Strain & 0.066 & 5 & 0.013 & 0.35 \\
$\quad$ Sex X Side X & 0.135 & 5 & 0.027 & 0.73 \\
$\quad$ Strain & & & & 1.60 \\
Replications & 0.535 & 9 & 0.059 & \\
\hline Errors & 7.615 & 207 & 0.037 & \\
\hline
\end{tabular}

1. Refer to foot-note in Table I.

**: Highly significant, based on 0.01 level. 
TABLE XXI. COMPARISON OF SAMPLE IEANS OF RATIO OF LONGITUDINAL/TRANSVERSE DIAIETER OF TMMPAIA OF SIX TELEOGRYLLUS STRAINS (AN AVERAGE OF TWO SIDES)

Compared Strains

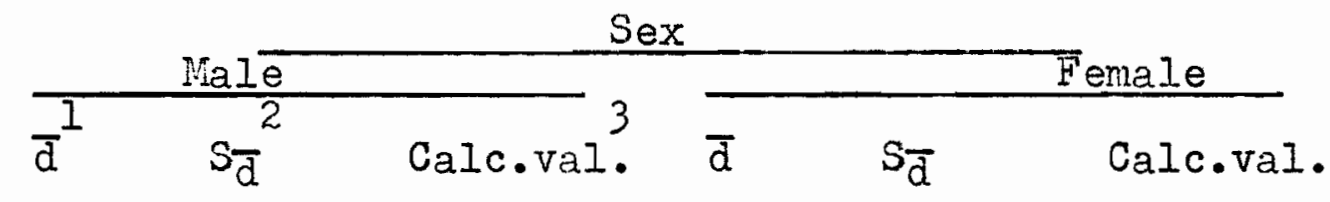

$\begin{array}{lllllll}Q a-Q w & 0.126 & 0.048 & 2.635 * & 0.103 & 0.104 & 0.990 \\ Q a-Q n & 0.334 & 0.080 & 4.175 * * & 0.254 & 0.079 & 3.215 * * \\ Q a-Q k & 0.424 & 0.055 & 7.709 * * & 0.329 & 0.084 & 3.917 * * \\ Q a-Q z & 0.119 & 0.067 & 1.776 & 0.023 & 0.081 & 0.284 \\ Q a-Q c & 0.039 & 0.056 & 0.696 & 0.042 & 0.101 & 0.416 \\ Q w-Q n & 0.208 & 0.078 & 2.667 * & 0.357 & 0.083 & 4.301 * * \\ Q w-Q k & 0.298 & 0.051 & 5.843 * * & 0.432 & 0.088 & 4.909 * * * \\ Q w-Q z & 0.007 & 0.065 & 0.108 & 0.080 & 0.085 & 0.941 \\ Q w-Q c & 0.087 & 0.053 & 1.642 & 0.061 & 0.104 & 0.586 \\ Q n-Q k & 0.090 & 0.082 & 1.098 & 0.075 & 0.056 & 1.339 \\ Q n-Q z & 0.215 & 0.091 & 2.363 * & 0.277 & 0.051 & 5.431 * * * \\ Q n-Q c & 0.295 & 0.083 & 3.554 * * & 0.296 & 0.079 & 3.747 * * \\ Q k-Q z & 0.305 & 0.070 & 4.357 * * & 0.352 & 0.059 & 5.966 * * \\ Q k-Q c & 0.385 & 0.059 & 6.525 * * & 0.371 & 0.084 & 4.417 * * \\ Q z-Q c & 0.080 & 0.071 & 1.127 & 0.019 & 0.081 & 0.235\end{array}$

1, 2, and 3 refer to foot-notes in Table II. *: Significant, based on 0.05 level, $d f=18$. **: Highly significant, based on 0.01 level, $d f=18$. 
TABLE XXII. RATIO OF LOHGITUDINAL/TRAINSVERSE DIAMETER

OF TYMPANA OF SIX TELEOGRYLLUS STRAINS

\begin{tabular}{|c|c|c|c|c|c|c|c|}
\hline Strain & Sex & $\begin{array}{l}\text { Specimens } \\
\text { Measured }\end{array}$ & $\bar{x}^{2}$ & $\underline{s}$ & $\begin{array}{l}\text { Range of } \\
\text { Individuals }\end{array}$ & $s_{\bar{x}}$ & Range of Mean ${ }^{1}$ \\
\hline $\mathrm{Qa}$ & $\begin{array}{l}\text { Male } \\
\text { Female }\end{array}$ & $\begin{array}{l}10 \\
10\end{array}$ & $\begin{array}{l}3.206 \\
3.182\end{array}$ & $\begin{array}{l}0.115 \\
0.223\end{array}$ & $\begin{array}{l}3.091-3.321 \\
2.959-3.405\end{array}$ & $\begin{array}{l}0.036 \\
0.071\end{array}$ & $\begin{array}{l}3.089-3.323 \\
2.951-3.413\end{array}$ \\
\hline$Q_{W}$ & $\begin{array}{l}\text { Male } \\
\text { Female }\end{array}$ & $\begin{array}{l}10 \\
10\end{array}$ & $\begin{array}{l}3.080 \\
3.285\end{array}$ & $\begin{array}{l}0.098 \\
0.239\end{array}$ & $\begin{array}{l}2.982-3.178 \\
3.046-3.524\end{array}$ & $\begin{array}{l}0.031 \\
0.076\end{array}$ & $\begin{array}{l}2.979-3.181 \\
3.038-3.532\end{array}$ \\
\hline$Q n$ & $\begin{array}{l}\text { Male } \\
\text { Female }\end{array}$ & $\begin{array}{l}10 \\
10\end{array}$ & $\begin{array}{l}2.872 \\
2.928\end{array}$ & $\begin{array}{l}0.225 \\
0.109\end{array}$ & $\begin{array}{l}2.647-3.097 \\
2.819-3.037\end{array}$ & $\begin{array}{l}0.071 \\
0.034\end{array}$ & $\begin{array}{l}2.641=3.103 \\
2.817=3.039\end{array}$ \\
\hline $\mathrm{Qk}$ & $\begin{array}{l}\text { Male } \\
\text { Female }\end{array}$ & $\begin{array}{l}10 \\
10\end{array}$ & $\begin{array}{l}2.782 \\
2.853\end{array}$ & $\begin{array}{l}0.129 \\
0.142\end{array}$ & $\begin{array}{l}2.653-2.911 \\
2.711-2.995\end{array}$ & $\begin{array}{l}0.041 \\
0.045\end{array}$ & $\begin{array}{l}2.649-2.915 \\
2.707-2.999\end{array}$ \\
\hline$Q z$ & $\begin{array}{l}\text { Male } \\
\text { Female }\end{array}$ & $\begin{array}{l}10 \\
10\end{array}$ & $\begin{array}{l}3.087 \\
3.205\end{array}$ & $\begin{array}{l}0.179 \\
0.121\end{array}$ & $\begin{array}{l}2.908-3.266 \\
3.084=3.326\end{array}$ & $\begin{array}{l}0.057 \\
0.038\end{array}$ & $\begin{array}{l}2.902-3.272 \\
3.081-3.329\end{array}$ \\
\hline de & $\begin{array}{l}\text { Male } \\
\text { Female }\end{array}$ & $\begin{array}{l}10 \\
10\end{array}$ & $\begin{array}{l}3.167 \\
3.224\end{array}$ & $\begin{array}{l}0.135 \\
0.224\end{array}$ & $\begin{array}{l}3.032-3.302 \\
3.000-3.448\end{array}$ & $\begin{array}{l}0.043 \\
0.071\end{array}$ & $\begin{array}{l}3.027-3.307 \\
2.993-3.455\end{array}$ \\
\hline
\end{tabular}

1. Refer to foot-note in Table III.

2. $\bar{x}$ is an average of both tympana (right and left). 
TABLE XXIII. LENGTH OF LONGITUDINAL AND TRANSVERSE DIANETERS OF TYMPANA IN SIX TELEOGRYLLUS STRAINS (AN AVERAGE OF TTO SIDES, I unit $=0.015 \mathrm{~mm}$ )

\begin{tabular}{|c|c|c|c|c|c|c|}
\hline Strain & Sex & $\begin{array}{l}\text { Specimens } \\
\text { Ileasured }\end{array}$ & $\begin{array}{l}\text { Mean of } \\
\text { Long. Diam. }\end{array}$ & $\begin{array}{l}\text { Range of } \\
\text { Measurements }\end{array}$ & $\begin{array}{l}\text { Mean of } \\
\text { Trans. Diam. }\end{array}$ & $\begin{array}{l}\text { Range of } \\
\text { Measurements }\end{array}$ \\
\hline Qa & $\begin{array}{l}\text { Male } \\
\text { Female }\end{array}$ & $\begin{array}{l}10 \\
10\end{array}$ & $\begin{array}{l}65.000 \\
64.925\end{array}$ & $\begin{array}{l}60.00-73.00 \\
60.00-70.00\end{array}$ & $\begin{array}{l}20 \cdot 300 \\
20.475\end{array}$ & $\begin{array}{l}19.00-21.00 \\
18.00-23.00\end{array}$ \\
\hline$Q w$ & $\begin{array}{l}\text { Male } \\
\text { Female }\end{array}$ & $\begin{array}{l}10 \\
10\end{array}$ & $\begin{array}{l}86.500 \\
72.650\end{array}$ & $\begin{array}{l}63.00-72.00 \\
62.00=80.00\end{array}$ & $\begin{array}{l}22.250 \\
22.200\end{array}$ & $\begin{array}{l}20.00-24.00 \\
20.00=24.00\end{array}$ \\
\hline Qn & $\begin{array}{l}\text { Male } \\
\text { Female }\end{array}$ & $\begin{array}{l}10 \\
10\end{array}$ & $\begin{array}{l}62.075 \\
60.900\end{array}$ & $\begin{array}{l}51.50-70.00 \\
53.50=66.00\end{array}$ & $\begin{array}{l}21.700 \\
20.825\end{array}$ & $\begin{array}{l}18.00-25.00 \\
18.00-22.00\end{array}$ \\
\hline Qk & $\begin{array}{l}\text { Male } \\
\text { Female }\end{array}$ & $\begin{array}{l}10 \\
10\end{array}$ & $\begin{array}{l}62.850 \\
62.850\end{array}$ & $\begin{array}{l}53.00-72.00 \\
57.00-68.00\end{array}$ & $\begin{array}{l}22.525 \\
22.075\end{array}$ & $\begin{array}{l}20.00-25.00 \\
20.00=24.00\end{array}$ \\
\hline$Q z$ & $\begin{array}{l}\text { Male } \\
\text { Female }\end{array}$ & $\begin{array}{l}10 \\
10\end{array}$ & $\begin{array}{l}64.000 \\
64.625\end{array}$ & $\begin{array}{l}59.00-69.00 \\
59.00-71.00\end{array}$ & $\begin{array}{l}20.800 \\
20.200\end{array}$ & $\begin{array}{l}17.00-23.00 \\
18.00-22.00\end{array}$ \\
\hline Qc & $\begin{array}{l}\text { Male } \\
\text { Female }\end{array}$ & $\begin{array}{l}10 \\
10\end{array}$ & $\begin{array}{l}62.350 \\
65.625\end{array}$ & $\begin{array}{l}43.00-70.00 \\
60.00-76.00\end{array}$ & $\begin{array}{l}19.700 \\
20.400\end{array}$ & $\begin{array}{l}15.00-22.00 \\
18.50-22.00\end{array}$ \\
\hline
\end{tabular}


TABLE XXIV. RATIO OF LENGTH/WIDTH OF ECTOPARAMERE OF SIX TELEOGRYLLUS STRAINS

\begin{tabular}{lcccc}
\multicolumn{5}{c}{ ANALYSIS OF VARIANCE $^{1}$} \\
SOURCE OF VARIATION & S.S. & df. & M.S. & F-VALUE \\
\hline Total & 5.119 & 59 & & \\
Strains & 2.739 & 5 & 0.548 & $15.22 \% * *$ \\
Replications & 0.742 & 9 & 0.082 & $2.28 *$ \\
\hline Errors & 1.638 & 45 & 0.036 & \\
\hline
\end{tabular}

TABLE XXV. RATIO OF MEASUREMENTS ${ }^{2}$ OF SECOND VALVIFER OF SIX TELEOGRYLLUS STRAINS

$$
\text { ANALYSIS OF VARIANCE }{ }^{1}
$$

\begin{tabular}{lcccc} 
SOURCE OF VARIATION & S.S. & df. & M.S. & F-VALUE \\
Total & 0.336 & 59 & & \\
Strains & 0.116 & 5 & 0.0232 & $5.95 * *$ \\
Replications & 0.046 & 9 & 0.0051 & 1.31 \\
\hline Errors & 0.174 & 45 & 0.0039 & \\
\hline
\end{tabular}

1. From Steel and Torrie (1960: $134-137$ ).

2. Refer to Fig. 20.

*: Significant, based on 0.05 level.

**: Highly significant, based on 0.01 level. 
TABLE XXVI. COMPARISON OF SAMPLE MEANS OF RATIO OF IENGTH/ WIDTH OF ECTOPARAMERES AND RATIO OF MEASUREMENTS OF SECOND VALVIFER OF SIX TELEOGRYLLUS STRAINS

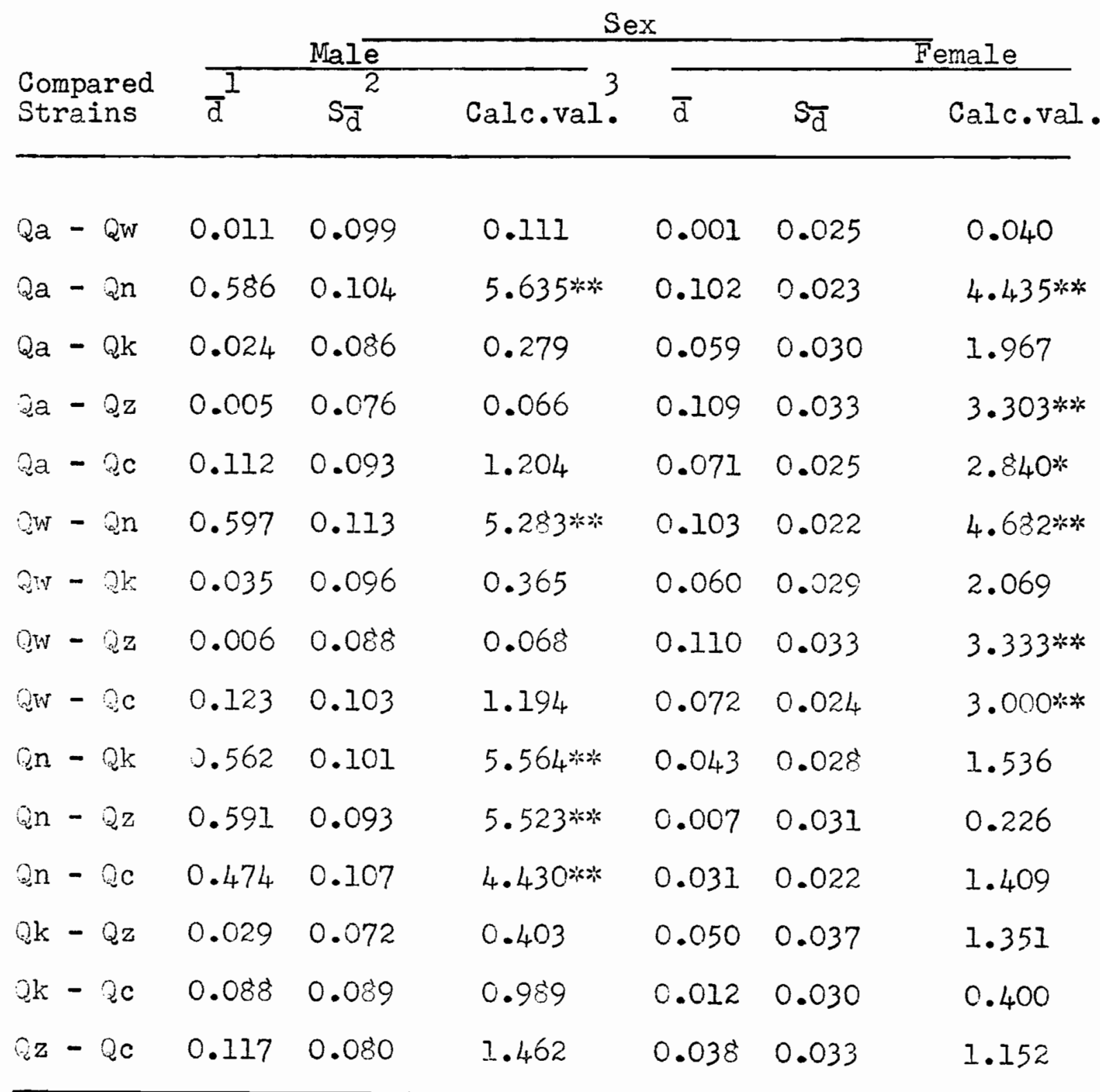

1, 2, and 3 refer to foot-notes in Table II.

*: Significant, based on 0.05 level, df $=18$.

**: Highly significant, based on 0.01 level, $\mathrm{d} f=18$. 
TABLE KXVII. RATIO OP LENGTH/NIDTH OF ECTOPARAMERE AND OF MEASUREMENTS OF SECOND VALVIFER OF SIX TELEOGRYLLUS STRAINS

\begin{tabular}{|c|c|c|c|c|c|c|c|}
\hline Strain & Sex & $\begin{array}{l}\text { Specimens } \\
\text { Measured }\end{array}$ & $\bar{x}$ & $s$ & $\begin{array}{l}\text { Range of } \\
\text { Individuals }\end{array}$ & $S_{\bar{x}}$ & Range of Mean ${ }^{1}$ \\
\hline Qa & $\begin{array}{l}\text { Male } \\
\text { Female }\end{array}$ & $\begin{array}{l}10 \\
10\end{array}$ & $\begin{array}{l}3.516 \\
1.473\end{array}$ & $\begin{array}{l}0.198 \\
0.057\end{array}$ & $\begin{array}{l}3.318-3.714 \\
1.416-1.530\end{array}$ & $\begin{array}{l}0.063 \\
0.018\end{array}$ & $\begin{array}{l}3.311-3.721 \\
1.415-3.531\end{array}$ \\
\hline Qw & $\begin{array}{l}\text { Wale } \\
\text { Female }\end{array}$ & $\begin{array}{l}10 \\
10\end{array}$ & $\begin{array}{l}3.505 \\
1.474\end{array}$ & $\begin{array}{l}0.243 \\
0.053\end{array}$ & $\begin{array}{l}3.262-3.748 \\
1.421=1.527\end{array}$ & $\begin{array}{l}0.077 \\
0.017\end{array}$ & $\begin{array}{l}3.255-3.755 \\
1.419-1.529\end{array}$ \\
\hline$Q n$ & $\begin{array}{l}\text { Male } \\
\text { Female }\end{array}$ & $\begin{array}{l}10 \\
10\end{array}$ & $\begin{array}{l}4.102 \\
1.371\end{array}$ & $\begin{array}{l}0.262 \\
0.046\end{array}$ & $\begin{array}{l}3.840-4.364 \\
1.325=1.417\end{array}$ & $\begin{array}{l}0.083 \\
0.015\end{array}$ & $\begin{array}{l}3.832=4.372 \\
1.324=1.418\end{array}$ \\
\hline $\mathrm{Qk}$ & $\begin{array}{l}\text { Male } \\
\text { Fenale }\end{array}$ & $\begin{array}{l}10 \\
10\end{array}$ & $\begin{array}{l}3.540 \\
1.414\end{array}$ & $\begin{array}{l}0.184 \\
0.076\end{array}$ & $\begin{array}{l}3.356-3.724 \\
1.338-1.490\end{array}$ & $\begin{array}{l}0.058 \\
0.024\end{array}$ & $\begin{array}{l}3.352-3.728 \\
1.336-1.498\end{array}$ \\
\hline$Q z$ & $\begin{array}{l}\text { Male } \\
\text { Female }\end{array}$ & $\begin{array}{l}10 \\
10\end{array}$ & $\begin{array}{l}3.511 \\
1.364\end{array}$ & $\begin{array}{l}0.133 \\
0.088\end{array}$ & $\begin{array}{l}3.378-3.644 \\
1.276-1.452\end{array}$ & $\begin{array}{l}0.042 \\
0.028\end{array}$ & $\begin{array}{l}3.375-3.647 \\
1.274-1.454\end{array}$ \\
\hline $\mathrm{ac}$ & $\begin{array}{l}\text { Male } \\
\text { Female }\end{array}$ & $\begin{array}{l}10 \\
10\end{array}$ & $\begin{array}{l}3.628 \\
1.402\end{array}$ & $\begin{array}{l}0.215 \\
0.054\end{array}$ & $\begin{array}{l}3.413=3.843 \\
1.348=1.456\end{array}$ & $\begin{array}{l}0.068 \\
0.017\end{array}$ & $\begin{array}{l}3.407-3.849 \\
1.34 .6-1.458\end{array}$ \\
\hline
\end{tabular}

1. Refer to foot-note in Table III.

2. Refer to Fig. 20 . 
TABLE XXVIII. LENGTH AID UIDTH OF ECTOFARAINERES IN MALES OF SIX TELEOGRYLIUS STRAINS (mm)

Specimens Mean of Range of Mean of Range of Strain Measured Length Measurements Vidth Measurements

$\begin{array}{llllll}\text { Qa } & 10 & 1.210 & 1.100-1.350 & 0.345 & 0.300-0.400 \\ Q w & 10 & 1.170 & 1.100-1.300 & 0.335 & 0.300-0.350 \\ Q \mathrm{n} & 10 & 1.350 & 1.250-1.500 & 0.330 & 0.300-0.350 \\ Q k & 10 & 1.220 & 1.150-1.300 & 0.345 & 0.300-0.350 \\ Q \mathrm{z} & 10 & 1.245 & 1.100-1.400 & 0.355 & 0.300-0.400 \\ Q \mathrm{c} & 10 & 1.270 & 1.150-1.400 & 0.350 & 0.350-0.350\end{array}$

1

TABLE YXIX. LENGTH OF IEASUREMPTS OF SECOND VALVIFER IN FEMALES OF SIX TELEOGRYLLUS STRAINS ( $\mathrm{mm}$ )

\begin{tabular}{ccccccc} 
Strain & $\begin{array}{c}\text { Specimens } \\
\text { Measured }\end{array}$ & $\begin{array}{c}\text { Mean } \\
\text { of AB }\end{array}$ & $\begin{array}{l}\text { Range Measurements } \\
\text { Mef }\end{array}$ & $\begin{array}{c}\text { Iean } \\
\text { of AC }\end{array}$ & $\begin{array}{l}\text { Range } \\
\text { Measurements }\end{array}$ \\
\hline $\mathrm{Qa}$ & 10 & 1.765 & $1.650-1.850$ & 1.200 & $1.050-1.300$ \\
$\mathrm{QW}$ & 10 & 1.760 & $1.650-1.850$ & 1.195 & $1.100-1.250$ \\
$\mathrm{Qn}$ & 10 & 1.590 & $1.450-1.700$ & 1.160 & $1.100-1.250$ \\
$\mathrm{Qk}$ & 10 & 1.645 & $1.550-1.750$ & 1.165 & $1.100-1.200$ \\
$\mathrm{Qz}$ & 10 & 1.615 & $1.400-1.750$ & 1.185 & $1.100-1.300$ \\
$\mathrm{Qc}$ & 10 & 1.605 & $1.500-1.700$ & 1.145 & $1.100-1.200$
\end{tabular}


TABLE XXX. RATIO OF EPIPROCT MEASUREMENTS ${ }^{2}$ OF
SIX TELEOGRYLLUS STRAINS (MALE)

\begin{tabular}{lcccc}
\multicolumn{5}{c}{ ANALYSIS OF VARIANCE $^{1}$} \\
SOURCE OF VARIATION & S.S. & df. & M.S. & F-VALUE \\
\hline Total & 0.200 & 59 & & \\
Strains & 0.128 & 5 & 0.0256 & $18.29 * *$ \\
Replications & 0.007 & 9 & 0.0008 & 0.57 \\
\hline Errors & 0.065 & 45 & 0.0014 & \\
\hline
\end{tabular}

TABLE NXXI. RATIO OF EPIPROCT MEASUREMENTS ${ }^{2}$ OF SIX TELEOGRYLLUS STRAINS (FEMALE)

\section{ANALYSIS OF VARIANCE ${ }^{1}$}

\begin{tabular}{lcccc} 
SOURCE OF VARIATION & S.S. & df. & M.S. & F-VALUE \\
Total & 0.150 & 59 & & \\
Strains & 0.093 & 5 & 0.0186 & $16.91 * *$ \\
Replications & 0.009 & 1 & 0.0010 & 0.91 \\
\hline Errors & 0.048 & 45 & 0.0011 & \\
\hline
\end{tabular}

1. Refer to foot-note in Table XXV.

2. Refer to Fig. 21 .

*: Highly significant, based on 0.01 level. 
TABLE XXXII. COMPARISON OF SAMPLE ITEAIS OF RATIO OT EPIPROCT IHEASUREMTITS OF SIX TELEOGRIIJUS STRAIIS

\begin{tabular}{|c|c|c|c|c|c|c|}
\hline \multirow{3}{*}{$\begin{array}{l}\text { Compared } \\
\text { Strains }\end{array}$} & \multicolumn{6}{|c|}{ Sex } \\
\hline & \multicolumn{3}{|c|}{ Male } & \multicolumn{3}{|c|}{ Female } \\
\hline & $\overline{\mathrm{d}}$ & $s_{\bar{d}}^{2}$ & Calc.val. & $\bar{d}$ & $s_{\bar{d}}$ & Calc.val \\
\hline $2 a-2 w$ & 0.056 & 0.015 & $3.111 * *$ & 0.005 & 0.014 & 0.357 \\
\hline $2 a-Q n$ & 0.133 & 0.014 & $9.500 * * * *$ & 0.110 & 0.013 & $8.462 * *$ \\
\hline$Q a-O k$ & 0.042 & 0.014 & $3.000 * 2 *$ & 0.007 & 0.017 & 0.412 \\
\hline $9 a-Q z$ & 0.002 & 0.015 & 0.133 & 0.007 & 0.014 & 0.500 \\
\hline $2 a-2 c$ & 0.074 & 0.019 & $3.895 * \cdots$ & 0.018 & 0.014 & 1.286 \\
\hline$Q w-2 n$ & 0.077 & 0.016 & $4.812 * * k$ & 0.115 & 0.012 & $9.583 * *$ \\
\hline$a w-2 k$ & 0.014 & 0.016 & 0.875 & 0.012 & 0.017 & 0.706 \\
\hline$O N-2 z$ & 0.058 & 0.017 & $3.412 * *$ & 0.07 .2 & 0.014 & 0.857 \\
\hline$g y-2 c$ & 0.018 & 0.020 & 0.900 & 0.023 & 0.013 & 1.769 \\
\hline $6 n-2 k$ & 0.091 & 0.013 & 7.000 秎 & 0.106 & 0.016 & $6.1438 * * * 6$ \\
\hline$Q n-Q z$ & 0.135 & 0.013 & $10.385 * *$ & 0.103 & 0.013 & $7.923 \% *$ \\
\hline $2 n-2 c$ & 0.059 & 0.018 & 3.27 है* & 0.092 & 0.012 & $7.667 \%$ \\
\hline$Q k-Q z$ & 0.044 & 0.013 & $3.385 * *$ & 0.000 & 0.017 & 0.000 \\
\hline $2 k-2 c$ & 0.032 & 0.018 & 1.778 & 0.011 & 0.017 & 0.647 \\
\hline $2 z-2 c$ & 0.076 & 0.018 & $4.222 * 3 k$ & 0.011 & 0.014 & 0.766 \\
\hline
\end{tabular}

I, 2, and 3 refer to foot-note in Table II.

*: Significant, based on 0.05 level, df $=18$.

*k: Highly significant, based on 0.01 level, if $=18$. 
2

TABLE XXXIII. IAIIO OF EPIPROCT IEASUREILUTS OF SIY TELEOGRYLIJS STRAINS

\begin{tabular}{|c|c|c|c|c|c|c|c|c|}
\hline Strain & Sex & $\begin{array}{l}\text { Specimens } \\
\text { Measured }\end{array}$ & $\bar{x}$ & $s$ & $\begin{array}{l}\text { Fange of } \\
\text { Individuals }\end{array}$ & $S_{\bar{x}}$ & Range & of Mean \\
\hline $2 a$ & $\begin{array}{l}\text { Male } \\
\text { Female }\end{array}$ & $\begin{array}{l}10 \\
10\end{array}$ & $\begin{array}{l}1.034 \\
1.070\end{array}$ & $\begin{array}{l}0.036 \\
0.032\end{array}$ & $\begin{array}{l}0.098-1.070 \\
1.038-1.102\end{array}$ & $\begin{array}{l}0.0114 \\
0.0101\end{array}$ & $\begin{array}{l}0.997 \\
1.037\end{array}$ & $\begin{array}{l}-1.071 \\
-1.103\end{array}$ \\
\hline $2 \mathrm{~W}$ & $\begin{array}{l}\text { I.jale } \\
\text { Female }\end{array}$ & $\begin{array}{l}10 \\
10\end{array}$ & $\begin{array}{l}1.090 \\
1.065\end{array}$ & $\begin{array}{l}0.042 \\
0.030\end{array}$ & $\begin{array}{l}1.048=1.132 \\
1.035-1.095\end{array}$ & $\begin{array}{l}0.0133 \\
0.0095\end{array}$ & $\begin{array}{l}1.047 \\
1.034\end{array}$ & $\begin{array}{l}-1.133 \\
-1.096\end{array}$ \\
\hline Qn & $\begin{array}{l}\text { Nale } \\
\text { Female }\end{array}$ & $\begin{array}{l}10 \\
10\end{array}$ & $\begin{array}{l}1.167 \\
1.180\end{array}$ & $\begin{array}{l}0.028 \\
0.024\end{array}$ & $\begin{array}{l}1.139-1.195 \\
1.156-1.204\end{array}$ & $\begin{array}{l}0.0089 \\
0.0076\end{array}$ & $\begin{array}{l}1.138 \\
1.155\end{array}$ & $\begin{array}{l}-1.196 \\
-1.205\end{array}$ \\
\hline $0 k$ & $\begin{array}{l}\text { Male } \\
\text { Female }\end{array}$ & $\begin{array}{l}10 \\
10\end{array}$ & $\begin{array}{l}1.076 \\
1.077\end{array}$ & $\begin{array}{l}0.028 \\
0.044\end{array}$ & $\begin{array}{l}1.048-1.104 \\
1.033-1.121\end{array}$ & $\begin{array}{l}0.0089 \\
0.0139\end{array}$ & $\begin{array}{l}1.047 \\
1.032\end{array}$ & $\begin{array}{l}-1.105 \\
-1.122\end{array}$ \\
\hline $2 z$ & $\begin{array}{l}\text { Filale } \\
\text { Female }\end{array}$ & $\begin{array}{l}10 \\
10\end{array}$ & $\begin{array}{l}1.032 \\
1.077\end{array}$ & $\begin{array}{l}0.032 \\
0.033\end{array}$ & $\begin{array}{l}1.000-1.064 \\
1.044-1.1 .10\end{array}$ & $\begin{array}{l}0.0101 \\
0.0104\end{array}$ & $\begin{array}{l}0.999 \\
1.043\end{array}$ & $\begin{array}{l}-1.065 \\
-1.111\end{array}$ \\
\hline Qc & $\begin{array}{l}\text { Ifale } \\
\text { Fernale }\end{array}$ & $\begin{array}{l}10 \\
10\end{array}$ & $\frac{1.108}{1.088}$ & $\begin{array}{l}0.048 \\
0.030\end{array}$ & $\begin{array}{l}1.060-1.156 \\
1.058-1.118\end{array}$ & $\begin{array}{l}0.0152 \\
0.0095\end{array}$ & $\begin{array}{l}1.059 \\
1.057\end{array}$ & $\begin{array}{l}-1.157 \\
-1.119\end{array}$ \\
\hline
\end{tabular}

1. Refer to foot-note in Table III.

2. Refer to FiE. $2 I$. 
TABLE XXXIV. LENGTH AND IIDTH OF EPIFTOCT IN SIX TELEOGRYLLUS STRAINS (mm)

\begin{tabular}{|c|c|c|c|c|c|c|}
\hline Strain & Sex & $\begin{array}{l}\text { Specimens: } \\
\text { Measured }\end{array}$ & $\begin{array}{l}\text { Mean of } \\
\text { Length }\end{array}$ & $\begin{array}{l}\text { Range of } \\
\text { Measurements }\end{array}$ & $\begin{array}{l}\text { Mean of } \\
\text { Vidth }\end{array}$ & $\begin{array}{l}\text { Range of } \\
\text { Measurements }\end{array}$ \\
\hline $\mathrm{Qa}$ & $\begin{array}{l}\text { Male } \\
\text { Female }\end{array}$ & $\begin{array}{l}10 \\
10\end{array}$ & $\begin{array}{l}1.845 \\
1.715\end{array}$ & $\begin{array}{l}1.600-1.950 \\
1.650-1.900\end{array}$ & $\begin{array}{l}1.785 \\
1.605\end{array}$ & $\begin{array}{l}1.650-2.000 \\
1.500-1.850\end{array}$ \\
\hline $\mathrm{QW}$ & $\begin{array}{l}\text { Male } \\
\text { Female }\end{array}$ & $\begin{array}{l}10 \\
10\end{array}$ & $\begin{array}{l}1.870 \\
1.740\end{array}$ & $\begin{array}{l}1.700-1.950 \\
1.600-1.900\end{array}$ & $\begin{array}{l}1.720 \\
1.635\end{array}$ & $\begin{array}{l}1.500-1.900 \\
1.450-1.800\end{array}$ \\
\hline$Q_{n}$ & $\begin{array}{l}\text { Male } \\
\text { Female }\end{array}$ & $\begin{array}{l}10 \\
10\end{array}$ & $\begin{array}{l}2.065 \\
1.875\end{array}$ & $\begin{array}{l}1.950-2.150 \\
1.800-2.000\end{array}$ & $\begin{array}{l}1.770 \\
1.590\end{array}$ & $\begin{array}{l}1.650-1.850 \\
1.500-1.700\end{array}$ \\
\hline Qk & $\begin{array}{l}\text { Male } \\
\text { Female }\end{array}$ & $\begin{array}{l}10 \\
10\end{array}$ & $\begin{array}{l}1.920 \\
1.780\end{array}$ & $\begin{array}{l}1.750-2.050 \\
1.650=1.900\end{array}$ & $\begin{array}{l}1.785 \\
1.655\end{array}$ & $\begin{array}{l}1.700-1.950 \\
1.550-1.800\end{array}$ \\
\hline $\mathrm{Qz}$ & $\begin{array}{l}\text { Male } \\
\text { Female }\end{array}$ & $\begin{array}{l}10 \\
10\end{array}$ & $\begin{array}{l}1.845 \\
1.695\end{array}$ & $\begin{array}{l}1.700-1.950 \\
1.600-1.900\end{array}$ & $\begin{array}{l}1.790 \\
1.575\end{array}$ & $\begin{array}{l}1.650-1.900 \\
1.450-1.750\end{array}$ \\
\hline$Q c$ & $\begin{array}{l}\text { Male } \\
\text { Female }\end{array}$ & $\begin{array}{l}10 \\
10\end{array}$ & $\begin{array}{l}1.835 \\
1.810\end{array}$ & $\begin{array}{l}1.750-2.000 \\
1.650-1.900\end{array}$ & $\begin{array}{l}1.660 \\
1.645\end{array}$ & $\begin{array}{l}1.500=1.850 \\
1.550=1.750\end{array}$ \\
\hline
\end{tabular}


TABLE XXXXV. NUMBER OF DENTICLES ON PROVENTRICULAR TEETH OF SIX TELEOGRYLLUS STRAINS

ANALYSIS OF VARIANCE ${ }^{I}$

\begin{tabular}{lrrrc} 
SOURCE OF VARIATION & S.S. & df. & M.S. & F-VALUE \\
Total & $29,999.09$ & 4319 & & \\
Strains & $1,151.19$ & 5 & 230.24 & $89.59 * *$ \\
Sexes & 6.79 & 1 & 6.79 & 2.64 \\
Individuals & $3,258.49$ & 59 & 55.23 & $21.49 * *$ \\
Rows & $14,509.70$ & 11 & $1,319.06$ & $513.25 * *$ \\
Columns & 19.09 & 5 & 3.82 & 1.49 \\
Replications & 178.19 & 4 & 44.55 & $17.33 * *$ \\
\hline Errors & $10,875.64$ & 4234 & 2.59 & \\
\hline
\end{tabular}

1. Refer to foot-note in Table I.

**: Highly significant, based on 0.01 level. 
TABLE WUXI. COIPARISON OF SAIPLE MEATS OF NUBBR OF DENTICLES ON PROVENTRICULAR TEDTH OF SIX TELEOGRYLLUS STRAINS (AN AVERAGE OF EACH TOOTH IN EACH ROW OF TEETH)

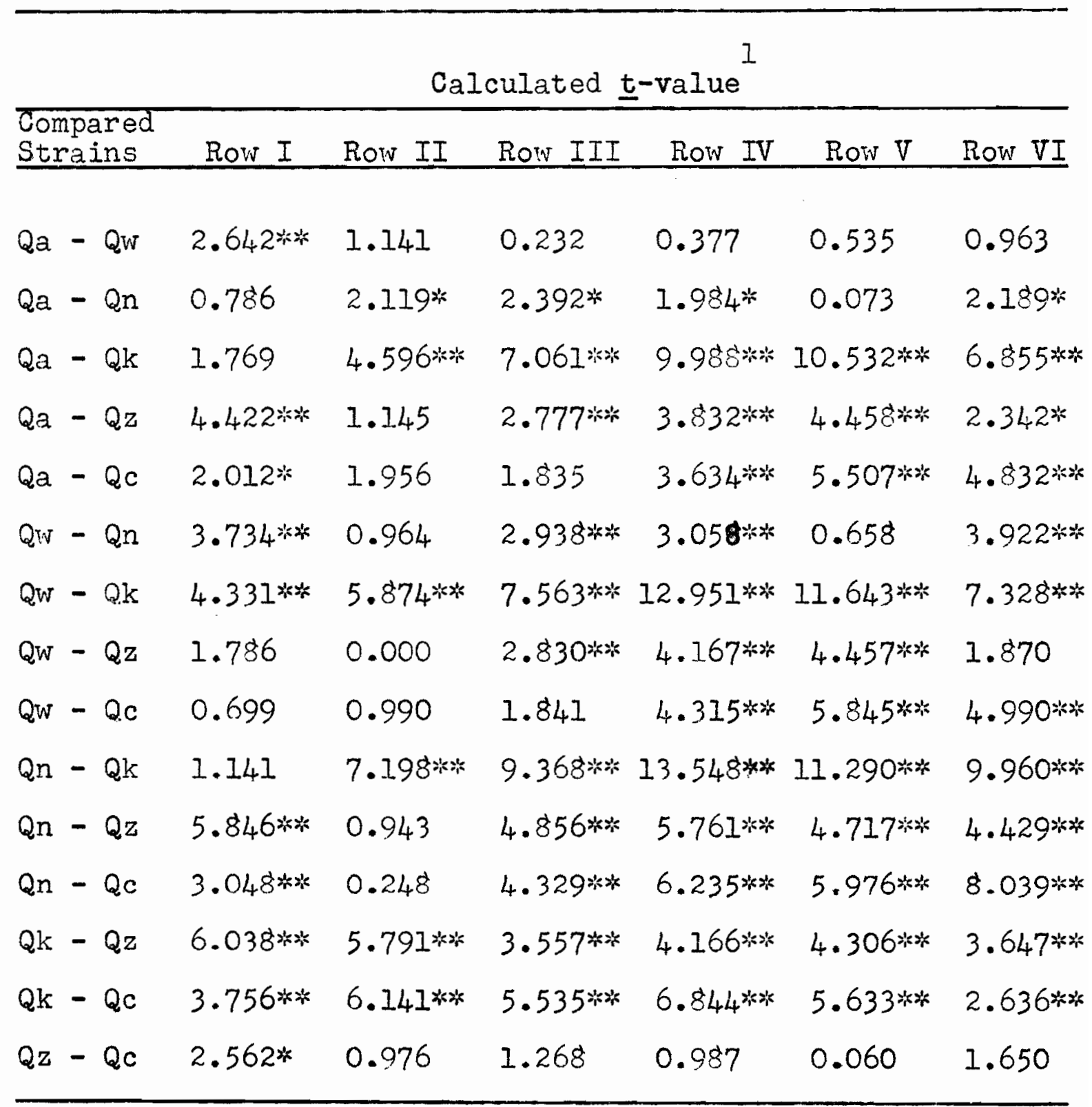

1. Refer to foot-notes 1,2 , and 3 in Table II.

*: Significant, based on 0.05 level, di $=118$. **: Highly significant, based on 0.01 level, df $=118$. 
TABLE XXXVI. Continued

\begin{tabular}{|c|c|c|c|c|c|c|}
\hline \multirow[b]{2}{*}{$\begin{array}{l}\text { Compared } \\
\text { Strains }\end{array}$} & \multicolumn{6}{|c|}{ Calculated $\underline{t}$-value ${ }^{l}$} \\
\hline & Row VII & Row VIII & Row IX & Row X & Row XI & Row XII \\
\hline$Q a-Q w$ & 1.299 & 1.051 & 0.132 & 1.415 & 1.853 & 0.865 \\
\hline$Q a-Q n$ & $3.664 * *$ & $2.652 * k^{*}$ & 1.769 & 0.694 & 0.814 & 0.122 \\
\hline Qa - Qk & $5.932 \% *$ & $5.703 \%$ & $6.302 * * *$ & $4.243 * \%$ & 0.933 & $2.346 \%$ \\
\hline$Q a-Q z$ & 1.909 & 1.576 & $2.374 *$ & 1.801 & 0.707 & 1.083 \\
\hline$Q a-Q c$ & 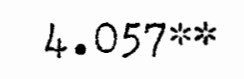 & $2.374 *$ & $3.169 * *$ & $2.237 \%$ & 1.185 & 1.549 \\
\hline$Q_{W}-Q_{n}$ & $5.505 *$ & $4.279 * * *$ & $1.982 *$ & 0.714 & $2.349 \%$ & 0.742 \\
\hline$Q w-Q k$ & $4.962 * \cdots$ & $5.480 \%$ & $7.612 *$ & $6.971 * *$ & 0.188 & $3.385 \%$ \\
\hline$Q_{W}-Q_{z}$ & 0.877 & 0.836 & $3.233 * 2 \pi$ & $3.496 * *$ & 0.590 & $2.128 *$ \\
\hline$Q w-Q c$ & $3.012 * *$ & 1.596 & $3.855 * *$ & $4.592 * *$ & $2.941 * * *$ & 0.820 \\
\hline$Q n-Q k$ & 10.798 & $9.362^{2 k}$ & $8.871 * *$ & $5.417 * *$ & 1.453 & $2.491 *$ \\
\hline$Q n-Q z$ & $5.184^{2 k^{2}}$ & 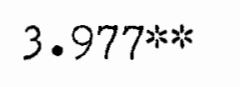 & $4.259 * * k$ & $2.598 *$ & 1.298 & 1.227 \\
\hline$Q n-Q c$ & $8.263 * 2 *$ & $5.558 *$ & $5.298 * * *$ & $3.275 * 2 *$ & 0.252 & 1.444 \\
\hline$Q k-Q z$ & $3.170 \% * \%$ & $3.212 * *$ & $3.528 * *$ & $2.128 \%$ & 0.269 & 1.469 \\
\hline$Q k-Q c$ & 1.638 & $3.623 * *$ & $3.108 * 2 *$ & $2.423 \%$ & 1.734 & $3.803 * 2 *$ \\
\hline$Q z-Q c$ & 1.661 & 0.379 & 0.618 & 0.124 & 1.611 & $2.700 \% *$ \\
\hline
\end{tabular}


TABLE YXXVII. NUMBER OF DENTICLES OF PROVENTRICULAR TSETH OF SIX TELEOGRYLLUS STRAINS

\begin{tabular}{|c|c|c|c|c|c|c|c|}
\hline Strain & Sex & $\begin{array}{l}\text { Specimens } \\
\text { Measured }\end{array}$ & $\bar{x}$ & $\mathbf{s}$ & $\begin{array}{l}\text { Range of } \\
\text { Individuals }\end{array}$ & $S^{5}$ & Range of Mean \\
\hline Qa & $\begin{array}{l}\text { Male } \\
\text { Female }\end{array}$ & $\frac{5}{5}$ & $\begin{array}{l}6.747 \\
6.103\end{array}$ & $\begin{array}{l}2.516 \\
2.173\end{array}$ & $\begin{array}{l}4.231-9.263 \\
3.930-8.276\end{array}$ & $\begin{array}{l}0.133 \\
0.114\end{array}$ & $\begin{array}{l}6.404-7.090 \\
5.809-6.397\end{array}$ \\
\hline Qw & $\begin{array}{l}\text { Male } \\
\text { Female }\end{array}$ & $\begin{array}{l}5 \\
5\end{array}$ & $\begin{array}{l}6.100 \\
6.608\end{array}$ & $\begin{array}{l}2.309 \\
2.209\end{array}$ & $\begin{array}{l}3.791=8.409 \\
4.399-8.817\end{array}$ & $\begin{array}{l}0.122 \\
0.116\end{array}$ & $\begin{array}{l}5.786-6.414 \\
6.309-6.907\end{array}$ \\
\hline $\sin$ & $\begin{array}{l}\text { Male } \\
\text { Female }\end{array}$ & $\begin{array}{l}5 \\
5\end{array}$ & $\begin{array}{l}6.014 \\
6.233\end{array}$ & $\begin{array}{l}2.076 \\
2.096\end{array}$ & $\begin{array}{l}3.938-8.090 \\
4.137-8.329\end{array}$ & $\begin{array}{l}0.109 \\
0.111\end{array}$ & $\begin{array}{l}5.733-6.295 \\
5.947-6.519\end{array}$ \\
\hline$Q k$ & $\begin{array}{l}\text { Male } \\
\text { Fenale }\end{array}$ & $\frac{5}{5}$ & $\begin{array}{l}7.753 \\
7.639\end{array}$ & $\begin{array}{l}2.891 \\
3.177\end{array}$ & $\begin{array}{ll}4.862 & -10.644 \\
4.462 & -10.816\end{array}$ & $\begin{array}{l}0.152 \\
0.168\end{array}$ & $\begin{array}{l}7.361-8.145 \\
7.206-8.072\end{array}$ \\
\hline $\mathrm{Qz}$ & $\begin{array}{l}\text { Male } \\
\text { Female }\end{array}$ & $\begin{array}{l}5 \\
5\end{array}$ & $\begin{array}{l}6.989 \\
6.419\end{array}$ & $\begin{array}{l}3.038 \\
2.910\end{array}$ & $\begin{array}{l}3.951-10.027 \\
3.509-9.329\end{array}$ & $\begin{array}{l}0.160 \\
0.153\end{array}$ & $\begin{array}{l}6.577-7.401 \\
6.025-6.813\end{array}$ \\
\hline$Q c$ & $\begin{array}{l}\text { Male } \\
\text { Female }\end{array}$ & $\begin{array}{l}5 \\
5\end{array}$ & $\begin{array}{l}6.708 \\
7.261\end{array}$ & $\begin{array}{l}2.553 \\
2.653\end{array}$ & $\begin{array}{l}4.155-9.261 \\
4.608-9.814\end{array}$ & $\begin{array}{l}0.135 \\
0.140\end{array}$ & $\begin{array}{l}6.360-7.056 \\
6.900-7.622\end{array}$ \\
\hline
\end{tabular}

1. Refer to foot-note in Table III, df $=359$.

2. Actual sample size is 5 (individuals) $\times 72$ (tooth number for each individual). 


\begin{tabular}{lrrrr}
\multicolumn{5}{c}{ ANALYSIS OF VARIANCE $^{1}$} \\
SOURCE OF VARIATION & S.S. & df. & M.S. & F-VALUE \\
\hline Total & 458,622 & 4,319 & & \\
Strains & 5,930 & 5 & $1,186.00$ & $101.80 * * *$ \\
Sexes & 21 & 1 & 21.00 & 1.80 \\
Individuals & 27,899 & 59 & 472.86 & $40.59 * * *$ \\
Rows & 373,488 & 11 & $33,953.45$ & $2,914.46 * *$ \\
Columns & 77 & 5 & 15.40 & 1.32 \\
Replications & 1,866 & 4 & 466.50 & $40.04 * *$ \\
\hline Errors & 49,341 & 4,234 & 11.65 & \\
\hline
\end{tabular}

1. Refer to foot-note in Table I.

**: Highly significant, based on 0.01 level. 
TABLE XXXIX. COMPARISON OF SAIMPLE MEAINS OF HEIGHT OF PROVENTRICULAR TEETH OF SIX TELEOGRYLLUS STRAINS (ANT AVIRAGE OF EACH TOOTH IN EACH ROW OF TEETH)

\begin{tabular}{|c|c|c|c|c|c|c|}
\hline \multirow[b]{2}{*}{$\begin{array}{l}\text { Compared } \\
\text { Strains } \\
\end{array}$} & \multicolumn{6}{|c|}{ Calculated $t$-value } \\
\hline & Row I & Row II & Row III & Row IV & Row V & Row VI \\
\hline$Q a-Q w$ & $2.844 * * 2 *$ & $6.538 \%$ & $4.927 \%$ & $5.909 * * *$ & $3.545 \%$ & $3.868 \% *$ \\
\hline$Q a-Q n$ & 0.450 & $2.894 * *$ & 0.577 & $3.110 \% * 2 \%$ & $4.338 \% *$ & $5.430 \%$ \\
\hline$Q a-Q k$ & 0.785 & 2.671 炏 & $6.078 * *$ & $5.008 * *$ & 1.429 & 0.422 \\
\hline$Q a-Q z$ & $4.104^{*} * * * x$ & $3.724 \div * *$ & 0.815 & 0.714 & 1.372 & $3.342 * * *$ \\
\hline$Q a-Q c$ & $2.884 * *$ & $6.713 * *$ & $3.283 * *$ & $3.267 * * *$ & $3.551 * *$ & $3.125 \%$ \\
\hline$Q w-Q n$ & $3.544 \% *$ & 8.501 冰 & $5.929 \% *$ & $3.211 * * \cdots$ & 0.814 & 1.679 \\
\hline$Q w-Q k$ & $3.692 * 3 \times$ & $7.823 * *$ & $10.421 * *$ & $11.077 * * *$ & $6.983 * \%$ & $3.839 * *$ \\
\hline$Q w-Q z$ & 1.257 & $2.190 \%$ & $5.116 * * *$ & $5.668 \% *$ & $2.674 * 2 *$ & 0.292 \\
\hline$Q w-Q c$ & 0.134 & 0.477 & 1.273 & $2.672 * *$ & 1.616 & 0.630 \\
\hline$Q n-Q k$ & 0.378 & 0.187 & $12.26 I^{*} * 2 *$ & $8.534 * \%$ & $6.396 \%$ & $5.670 * *$ \\
\hline$Q n-Q z$ & $5.116 * 2 *$ & $5.760 \%$ & 0.398 & $3.314 * 2 *$ & $2.145 *$ & 1.788 \\
\hline$Q n-Q c$ & $3.638 * *$ & $8.571 * *$ & $4.048 ; * ; k$ & 0.363 & 0.852 & $2.202 \%$ \\
\hline$Q k-2 z$ & $5.000 * *$ & $5.382^{2}$ & $4.541 * * 2$ & $3.508 *$ & $2.682^{2}$ & $3.225 \%$ \\
\hline$Q k-Q c$ & $3.772^{2}$ & $7.957 * * *$ & $8.543 \%$ & $8.397 * *$ & $5.484^{i * 3 * x}$ & $2.992 \% *$ \\
\hline$Q z-Q c$ & 1.544 & $2.565 \%$ & $3.669 * *$ & $3.464 *$ & 1.522 & 0.300 \\
\hline
\end{tabular}

1. Refer to foot-notes 1,2 , and 3 in Table II.

*: Significant, based on 0.05 level, df $=118$. **: Highly significant, based on 0.01 level, df $=118$. 
TABLE XXXIX. Continued

1

Calculated $\underline{t}$-value

\begin{tabular}{|c|c|c|c|c|c|c|}
\hline $\begin{array}{l}\text { Compared } \\
\text { Strains } \\
\end{array}$ & Row VII & Row VIII & Row IX & Row $X$ & Row XI & Row XII \\
\hline$Q a-Q w$ & $4.071 * *$ & $2.180 *$ & $2.188 \%$ & 1.094 & 0.123 & .164 \\
\hline $2 a-2 n$ & $6.034 \%$ & 3.673 弪水 & $4.226 * * *$ & $3.699 * \%$ & $3.006 * 2 *=$ & $2.249^{2} \mathrm{k}$ \\
\hline$Q a-Q k$ & $1.983 *$ & 1.041 & 0.089 & $2.826 \% *$ & $3.803 *$ & $3.317 * * 1$ \\
\hline$Q a-Q z$ & $3.816 * 2 *$ & $3.182^{k * k}$ & $2.376 \%$ & $3.316 \%$ & $3.693 \% * *$ & $2.299 \%$ \\
\hline$Q a-Q c$ & $3.648 \% *$ & $3.276 * * *$ & $4.821 * *$ & $7.250 \%$ & $6.662 * 2 *$ & 0.682 \\
\hline$Q w-Q n$ & $2.330 \%$ & 1.765 & $2.000 *$ & $2.567 \%$ & $3.261 * *$ & $2.743 \%$ \\
\hline$Q W-Q k$ & $2.132 \%$ & 1.292 & 1.952 & 1.754 & $3.945 * *$ & $3.913^{* k+k}$ \\
\hline$Q w-2 z$ & 0.147 & 1.455 & 0.285 & $2.164 *$ & $4.016 * *$ & 2.791 洪 \\
\hline$Q w-Q c$ & 0.139 & 1.483 & $2.934 *$ & $6.171 * *$ & $7.252 * *$ & 0.956 \\
\hline $2 n-Q k$ & $4.263 * 3 * 6$ & $3.013 * *$ & $3.840 \% * k$ & 0.723 & 0.947 & 1.454 \\
\hline$Q n-Q z$ & 1.859 & 0.000 & 1.614 & 0.480 & 0.463 & 0.084 \\
\hline$Q n-Q c$ & 1.742 & 0.061 & 1.280 & $3.764 * *$ & $2.995 * * *$ & 1.908 \\
\hline$Q k-Q z$ & $2.033 *$ & $2.507 *$ & $2.146 *$ & 0.280 & 0.583 & 1.360 \\
\hline$Q k-Q c$ & 1.929 & $2.596 \%$ & $4.484 * *$ & $4.335 \%$ & 1.559 & $3.206 * \frac{1}{k}$ \\
\hline$Q z-Q c$ & 0.000 & 0.052 & $2.581 \%$ & $4 \cdot 300 * * * *$ & $2.740 * *$ & 1.969 \\
\hline
\end{tabular}


TABLE XL. HEIGHT OF PROVENTRICULAR TEETH OF SIX TELEOGRYLLUS STRAINS ( I unit $=0.0063 \mathrm{~mm}$ )

\begin{tabular}{|c|c|c|c|c|c|c|c|}
\hline Strajn & Sex & $\begin{array}{l}\text { Specimens } \\
\text { Measured }\end{array}$ & $\bar{x}$ & $s$ & $\begin{array}{l}\text { Range of } \\
\text { Individuals }\end{array}$ & $S_{\bar{x}}$ & Range of Mean \\
\hline Qa & $\begin{array}{l}\text { Male } \\
\text { Fernale }\end{array}$ & $\begin{array}{l}5 \\
5\end{array}$ & $\begin{array}{l}21.853 \\
22.031\end{array}$ & $\begin{array}{l}10.103 \\
10.250\end{array}$ & $\begin{array}{l}11.750-31.956 \\
11.781-32.281\end{array}$ & $\begin{array}{l}0.535 \\
0.540\end{array}$ & $\begin{array}{l}20.475-23.231 \\
20.640-23.422\end{array}$ \\
\hline Qw & $\begin{array}{l}\text { Male } \\
\text { Female }\end{array}$ & $\begin{array}{l}5 \\
5\end{array}$ & $\begin{array}{l}17.886 \\
21.375\end{array}$ & $\begin{array}{l}8.734 \\
9.546\end{array}$ & $\begin{array}{r}9.152-26.620 \\
11.829-30.921\end{array}$ & $\begin{array}{l}0.460 \\
0.503\end{array}$ & $\begin{array}{l}16.701-19.071 \\
20.079-22.671\end{array}$ \\
\hline Qn & $\begin{array}{l}\text { Hale } \\
\text { Female }\end{array}$ & $\begin{array}{l}5 \\
5\end{array}$ & $\begin{array}{l}21.122 \\
19.219\end{array}$ & $\begin{array}{l}9.758 \\
9.166\end{array}$ & $\begin{array}{l}11.364-30.880 \\
10.053-28.385\end{array}$ & $\begin{array}{l}0.514 \\
0.483\end{array}$ & $\begin{array}{l}19.798-22.446 \\
17.975-20.463\end{array}$ \\
\hline Qk & $\begin{array}{l}\text { Male } \\
\text { Female }\end{array}$ & $\begin{array}{l}5 \\
5\end{array}$ & $\begin{array}{l}22.017 \\
22.022\end{array}$ & $\begin{array}{l}10.977 \\
1.1 .700\end{array}$ & $\begin{array}{l}11.040-32.994 \\
10.322-33.722\end{array}$ & $\begin{array}{l}0.579 \\
0.623\end{array}$ & $\begin{array}{l}20.525=23.509 \\
20.417-23.627\end{array}$ \\
\hline$Q z$ & $\begin{array}{l}\text { Male } \\
\text { Female }\end{array}$ & $\begin{array}{l}5 \\
5\end{array}$ & $\begin{array}{l}20.589 \\
19.386\end{array}$ & $\begin{array}{l}10.892 \\
10.683\end{array}$ & $\begin{array}{l}9.697-31.481 \\
8.703-30.069\end{array}$ & $\begin{array}{l}0.574 \\
0.563\end{array}$ & $\begin{array}{l}19.110-22.068 \\
17.936-20.836\end{array}$ \\
\hline$Q c$ & $\begin{array}{l}\text { Male } \\
\text { Female }\end{array}$ & $\begin{array}{l}5 \\
5\end{array}$ & $\begin{array}{l}18.708 \\
18.975\end{array}$ & $\begin{array}{l}10.310 \\
10.073\end{array}$ & $\begin{array}{l}8.398-29.018 \\
8.902-29.048\end{array}$ & $\begin{array}{l}0.544 \\
0.531\end{array}$ & $\begin{array}{l}17.307-20.109 \\
17.607-20.343\end{array}$ \\
\hline
\end{tabular}

1. Refer to foot-note in Table III, df $=359$.

2. Refer to foot-note in Table XXXVII. 
TABLE XLI. SUMMARY OF RESULTS OBTAIHED IN TABLDS OF COMPARISON OF SAMPLE ITEANS

\begin{tabular}{|c|c|c|c|c|c|c|}
\hline \multirow{2}{*}{$\begin{array}{l}\text { Compared } \\
\text { Strains } \\
\end{array}$} & \multicolumn{2}{|c|}{$\begin{array}{l}\text { Ratio of Body } \\
\text { Measurements }\end{array}$} & \multicolumn{2}{|c|}{$\begin{array}{l}\text { Ratio of Frons } \\
\text { Measurements }\end{array}$} & \multicolumn{2}{|c|}{$\begin{array}{l}\text { Ratio of Pronotum } \\
\text { Measurements }\end{array}$} \\
\hline & Male & Female & Male & Female & Male & Female \\
\hline$Q a-Q w$ & $0.288^{2}$ & 0.647 & $9.500 * * *$ & 8.950 ; $* 3$ & $3.100^{2} x^{2}$ & $3.222 * 2 \%$ \\
\hline$Q a-Q n$ & $2.538 \%$ & $3.000 * *$ & 0.667 & $6.444 \% *$ & $4.658{ }^{2} x^{2}$ & $2.657 *$ \\
\hline $2 a-2 k$ & 0.674 & 1.742 & $3.438 \% * \%$ & 0.357 & 1.513 & 1.000 \\
\hline$Q a-Q z$ & $3.280 \% * *$ & 0.545 & 1.870 & 1.700 & 1.312 & $2.182 \%$ \\
\hline$Q a-Q c$ & 1.370 & 1.740 & 0.357 & $2.409 \%$ & 0.167 & 0.062 \\
\hline$Q n-Q n$ & $2.221 *$ & $3.750 * * * *$ & $5.750 * * *$ & $3.938 * *$ & $6.585 \%$ & 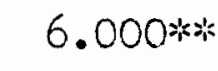 \\
\hline$Q W-Q k$ & 0.774 & 1.725 & $10.350 * * *$ & $7.269 * \cdots$ & $3.619 * *$ & $5.273 * 2 *$ \\
\hline$Q w-Q z$ & $2.164 *$ & 0.092 & $4.192 * * *$ & $8.056 \%$ & $3.857 \% * ;$ & 0.536 \\
\hline$Q W-Q c$ & 0.786 & 1.741 & $8.278 * *$ & $6.000 * * 2 *$ & 2.020 & $3.269 * * *$ \\
\hline$Q n-Q k$ & $2.191 \%$ & 1.196 & $2.875 \%$ & $5.040 \% *$ & $2.458 \%$ & $2.064 *$ \\
\hline $2 n-2 z$ & $5.585 \% 2 \%$ & $3.384 * * *$ & 1.000 & $5.125 * * *$ & $3.214 * 2 k$ & $4.714 * * * x$ \\
\hline$Q n-Q c$ & 3.614 * & 1.343 & 0.409 & $3.316 * 2 *$ & 3.073 & $2.794 *$ \\
\hline$Q k-Q z$ & $4.386 * * ;$ & 1.630 & $3.769 * * ;$ & 1.692 & 0.386 & $3.607 * *$ \\
\hline$Q k-Q c$ & $2.102 *$ & 0.079 & $3.333 * *$ & $2.250 *$ & 0.911 & 1.107 \\
\hline$Q z-Q c$ & 1.636 & 1.638 & 1.520 & 0.905 & 0.667 & $2.121 *$ \\
\hline
\end{tabular}

1. From Tables II, VI, X, XIV, XVII, XXI, VXVI and XXXI.

2. Calculated $\underline{t}$-values.

*: Significant, based on 0.05 level, df $=18$.

**: Highly significant, based on 0.01 level, df $=18$. 
TABLE XII. Continued 1.

\begin{tabular}{|c|c|c|c|c|c|c|}
\hline \multirow{2}{*}{$\begin{array}{l}\text { Compared } \\
\text { Strains } \\
\end{array}$} & \multicolumn{2}{|c|}{$\begin{array}{l}\text { Number of Pegs on } \\
\text { Stridulatory Vein }\end{array}$} & \multicolumn{2}{|c|}{$\begin{array}{l}\text { Ratio of Foreleg } \\
\text { Measurements }\end{array}$} & \multicolumn{2}{|c|}{$\begin{array}{l}\text { Ratio of Tympanum } \\
\text { Measurements }\end{array}$} \\
\hline & Right & Left & Iale & Bernale & Male & Female \\
\hline$Q a-Q w$ & 0.424 & 0.845 & 1.111 & 1.556 & $2.625 \%$ & 0 . \\
\hline$Q a-Q n$ & $13.857 \% *$ & $11.297 * * *$ & $* 3.556 \% *$ & $3.333 * *$ & $4.175 * *$ & $3.215 * * ;$ \\
\hline$Q a-Q k$ & 0.675 & 1.355 & 0.800 & $3.200 \% *$ & $7.709 * *$ & $3.917 *$ \\
\hline$a-2 z$ & 1.180 & $2.725 *$ & 0.600 & 0.700 & 1.776 & 0.284 \\
\hline $2 a-Q c$ & 1.783 & $2.193 *$ & 0.167 & 0.500 & 0.696 & 0.416 \\
\hline$Q w-\partial n$ & $14.758 * *$ & $12.833 * *$ & $=6.000 \% *$ & $4.400 * * *$ & $2.667 \%$ & $4.301 * 2$ \\
\hline $2 \mathrm{~W}-\mathrm{Qk}$ & 0.449 & 0.870 & $2.250 *$ & $4.182 * *$ & $5.843 \% *$ & $4.909 *$ \\
\hline$Q w-Q z$ & 0.975 & $2.636 \%$ & 2.000 & 1.909 & 0.108 & 0.941 \\
\hline$Q w-Q c$ & 1.613 & 1.940 & 1.200 & 1.727 & 1.642 & 0.586 \\
\hline$Q n-Q k$ & $12.033 *$ & $11.999 * *$ & $=3.000 * *$ & 0.182 & 1.098 & 1.339 \\
\hline$\partial n-\partial z$ & $14.303 * 2 k$ & $13.456 * *$ & $=3.250 * * *$ & 2.091 & $2.363 *$ & $5.431 *$ \\
\hline$Q n-Q c$ & $14.703 x^{2}=2$ & $13.177^{*}=* k$ & $3.000 * * ;$ & $2.273 *$ & $3.554 * 2 *$ & $3.747^{\circ}$ \\
\hline $2 k-2 z$ & 0.169 & 1.119 & 0.250 & $2.273 *$ & $4.357 * 2 *$ & $5.966 \%$ \\
\hline$Q k-Q c$ & 0.584 & 0.591 & 0.545 & $2.454 * 6$ & 0.525 & $4.417 * x$ \\
\hline$Q z-Q c$ & 0.562 & 0.640 & 0.364 & 0.182 & 1.127 & 0.235 \\
\hline
\end{tabular}


TABLE YLI. Continued 2.

\begin{tabular}{|c|c|c|c|c|}
\hline \multirow{2}{*}{$\begin{array}{l}\text { Compared } \\
\text { Strains }\end{array}$} & \multicolumn{2}{|c|}{$\begin{array}{l}\text { Ratio of Genitalia } \\
\text { Measurements }\end{array}$} & \multicolumn{2}{|c|}{$\begin{array}{l}\text { Ratio of Epiproct } \\
\text { Measurements }\end{array}$} \\
\hline & Male & Female & Male & Female \\
\hline$Q a-Q w$ & 0.111 & 0.040 & 3.111 标水 & 0.357 \\
\hline $\mathrm{Qa}-\mathrm{Qn}$ & $5.635 * *$ & $4.435 * *$ & $9.500 * * *$ & $8.462 * *$ \\
\hline $2 a-2 k$ & 0.279 & 1.967 & $3.000 * * ;$ & 0.412 \\
\hline $2 a-Q z$ & 0.066 & $3.303 * *$ & 0.133 & 0.500 \\
\hline $2 a-2 c$ & 1.204 & $2.840 \%$ & $3.895 * k * k$ & 1.286 \\
\hline $2 w-2 n$ & $5.283 x * *$ & $4.682 * *$ & $4.812 * k *$ & $9.583 * * *$ \\
\hline $6 w-2 k$ & 0.365 & 2.059 & 0.875 & 0.706 \\
\hline$Q W-Q z$ & 0.068 & $3.333 * *$ & $3.412 * * *$ & 0.857 \\
\hline $2 w-2 c$ & 1.194 & $3.000 * *$ & 0.900 & 1.769 \\
\hline$a n-a k$ & $5.564 * * *$ & 1.536 & $7.000 * \%$ & $6.4388^{2}=\cdots$ \\
\hline $2 n-2 z$ & $5.523 * *$ & 0.226 & $10.385 * *$ & $7.923^{2 * * *}$ \\
\hline$Q n-Q c$ & $4 \cdot 430 * 2 *$ & 1.409 & $3.278 * *$ & 7.667 棌** \\
\hline $\mathrm{C} k-\mathrm{Qz}$ & 0.403 & 1.351 & $3.365 *$ & 0.000 \\
\hline $2 k-2 c$ & 0.983 & 0.400 & 1.778 & 0.647 \\
\hline $9 z-2 c$ & 1.462 & 1.152 & $4.222 * * k$ & 0.786 \\
\hline
\end{tabular}




\section{FIGURES}

\section{From $I$ to 40}


Fig. 1. Frontal view of head of Qn strain (Teleogryllus oceanicus (Le Guillou)).

a: length of frons

$b$ : width of frons 

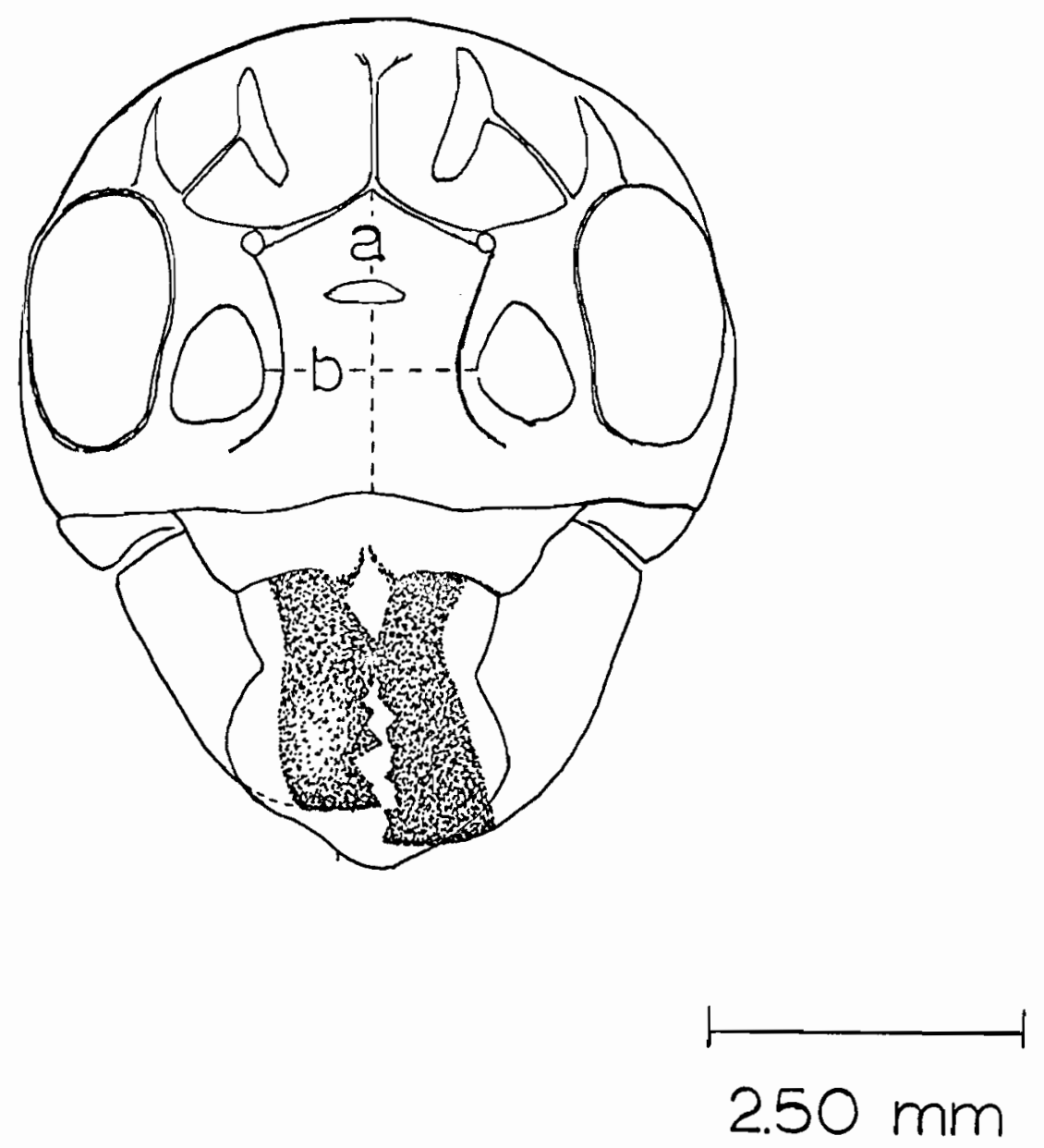
Fig. 2. Dorsal view of pronotum, Qn strain (Teleogryllus oceanicus (Le Guiliou)).

a: length of pronatum

$\mathrm{b}$ : width of pronotum (flattened) 

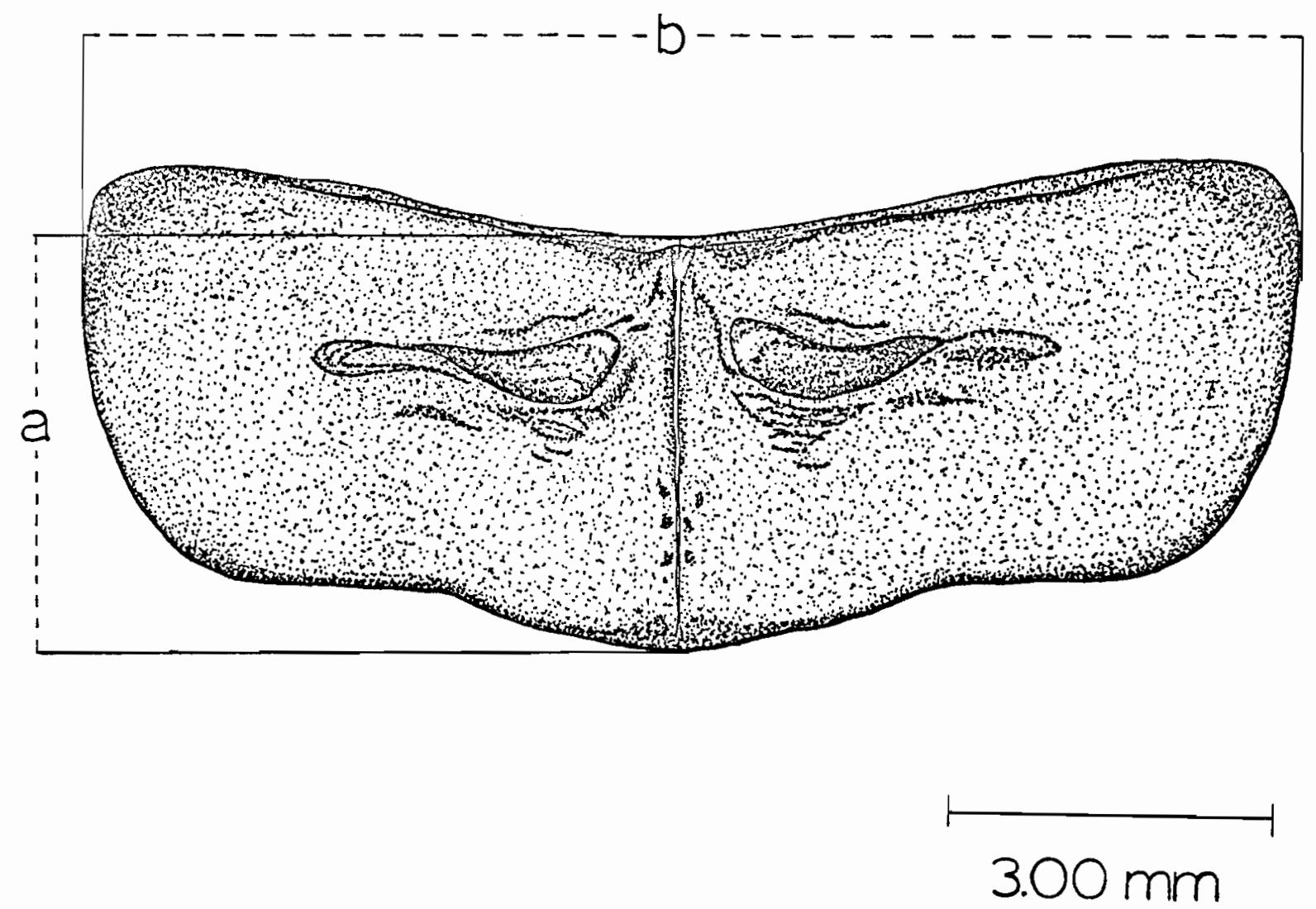
Fig. 3. Shape of pegs on stridulatory vein, Qa strain.

Fig. 4. Shape of pegs on stridulatory vein, $Q w$ strain (Teleogryllus commodus (Walker)). 

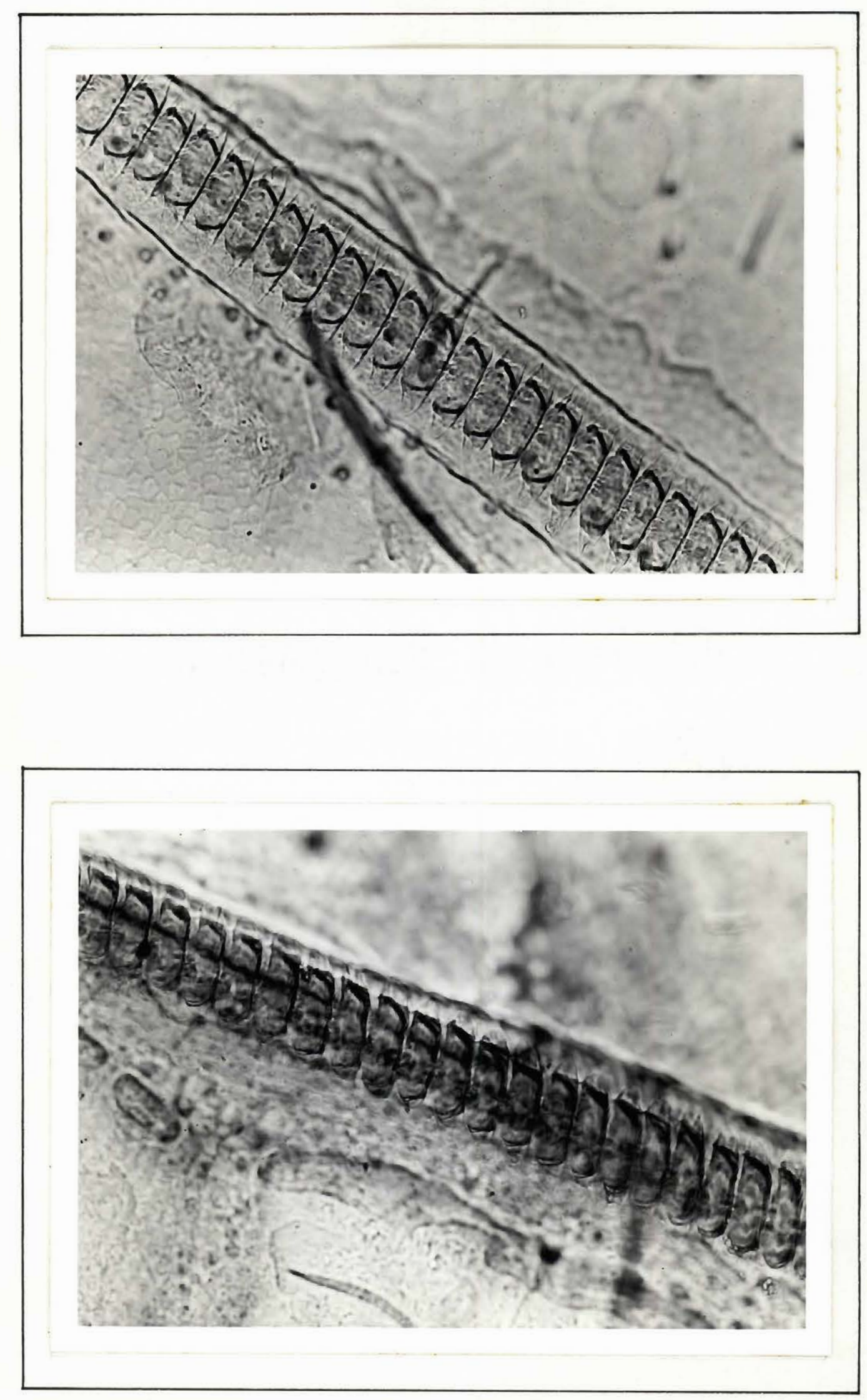
Fig. 5. Shape of pegs on stridulatory vein, Qn strain (Teleogryllus oceanicus (Le Guillou)).

Fig. 6. Shape of pegs on stridulatory vein, Qk strain. 

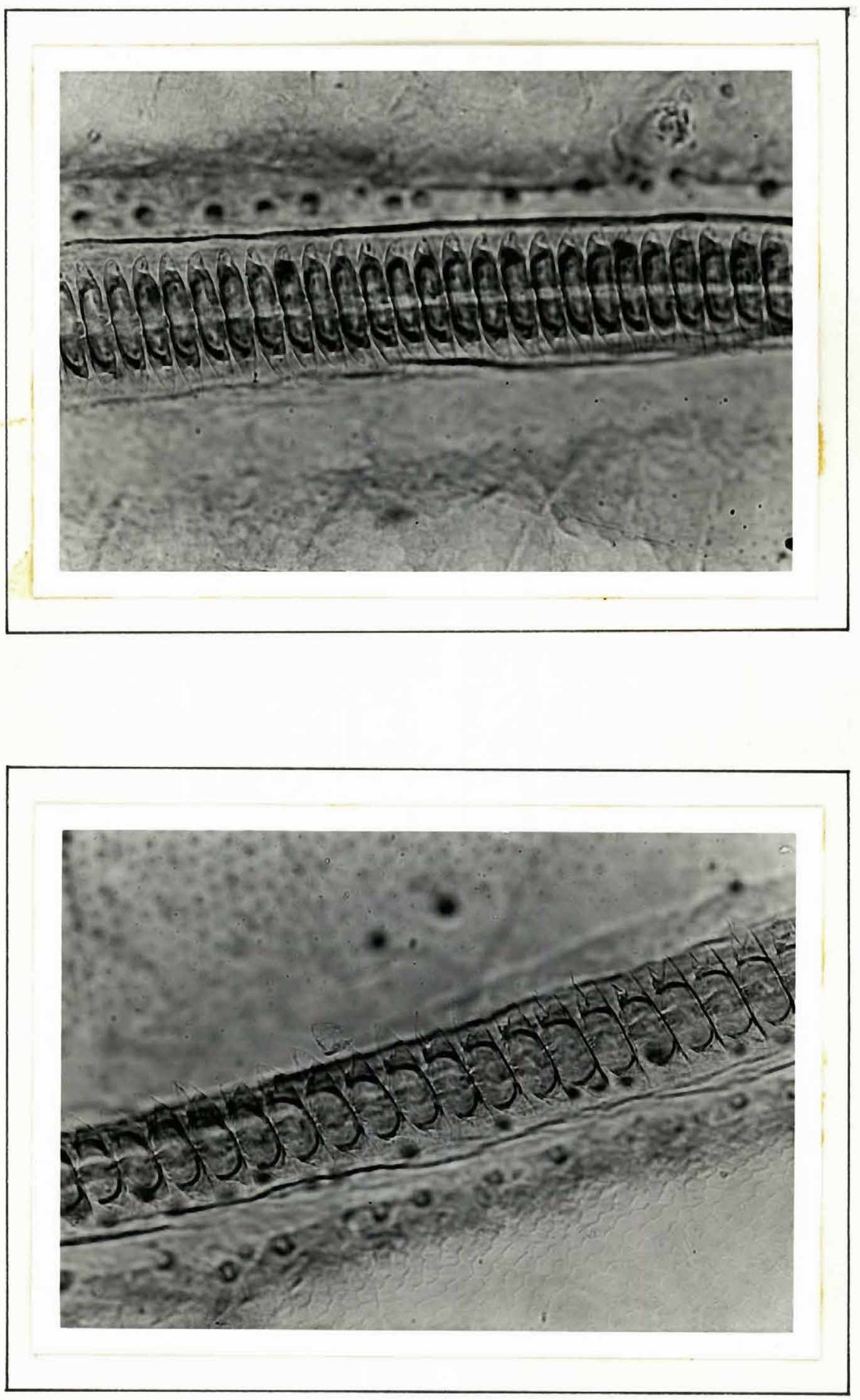
Fig. 7. Shape of pegs on stridulatory vein, Qz strain.

Fig. 8. Shape of pegs on stridulatory vein, Qc strain. 

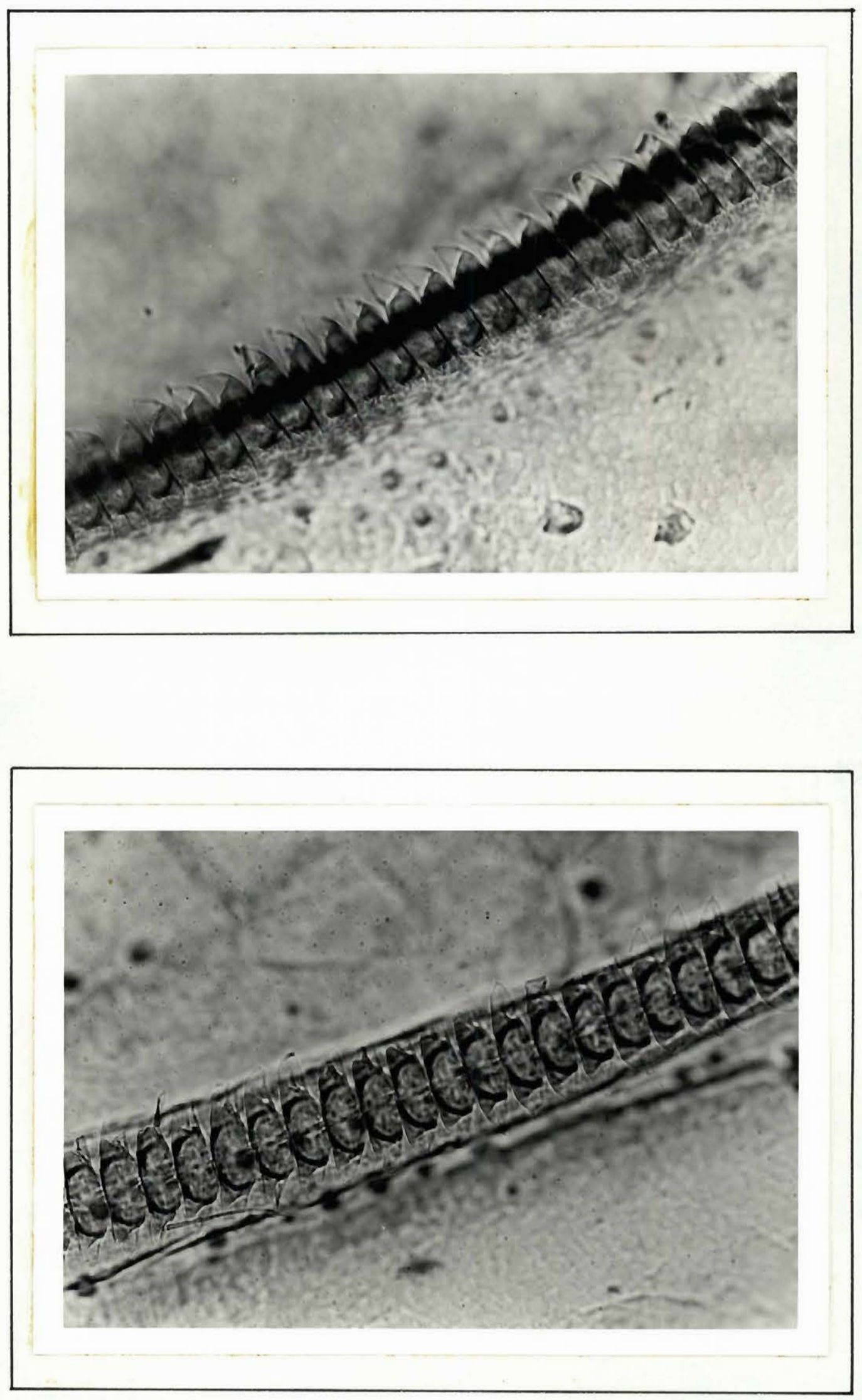
Fig. 9. Shape of pegs on stridulatory vein, Teleogryllus oceanicus (Le Guillou), Hawaiian specimen. 


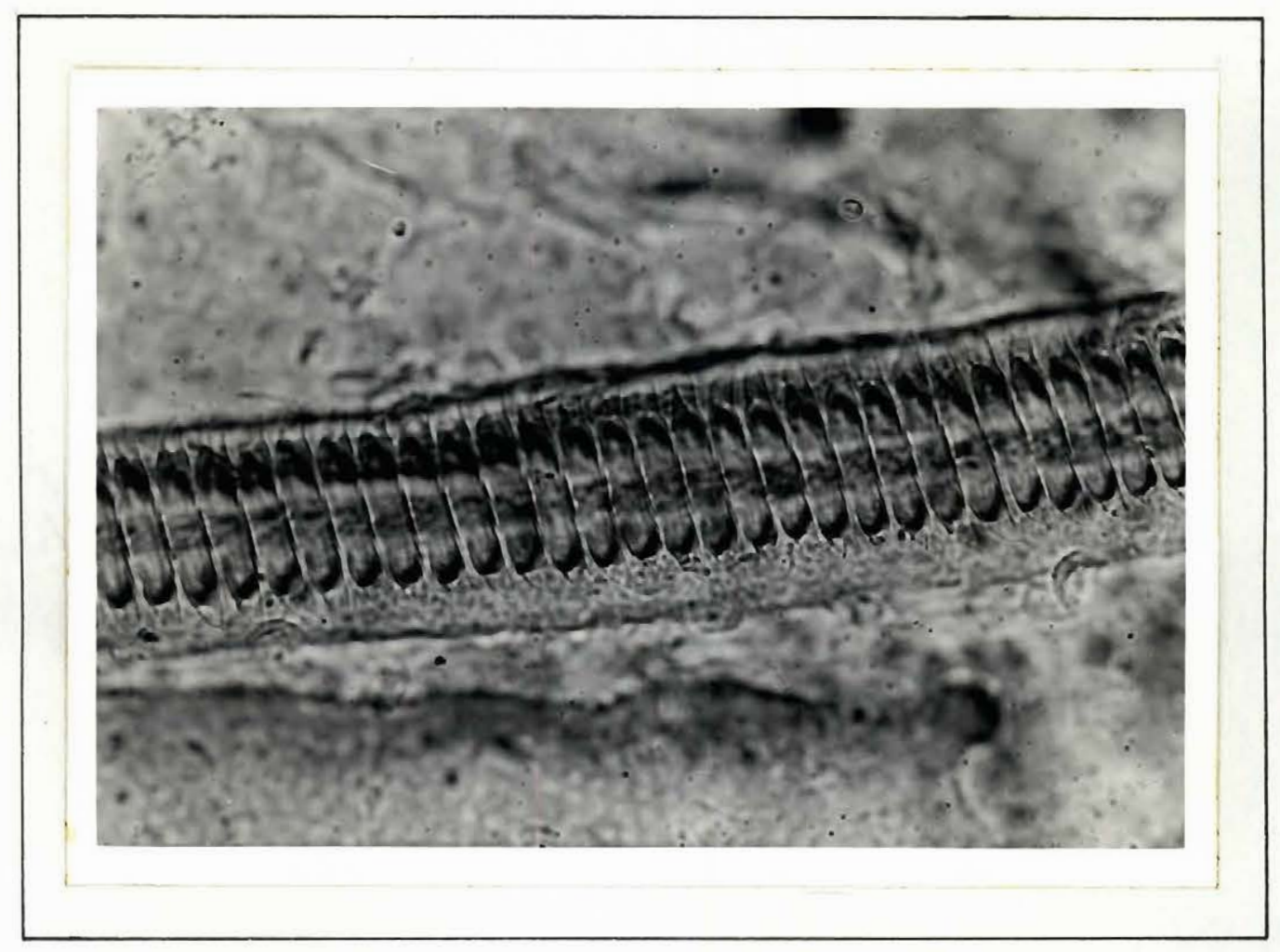


Fig. 10. Shape of tip of tympanum of tegmen, Qn strain (Teleogryllus oceanicus (Le Guillou)).

Fig. 11. Shape of tip of tympanum of tegmen, Teleogryllus oceanicus (Le Guillou), Hawaiian specimen. 
-

$Q_{n}$
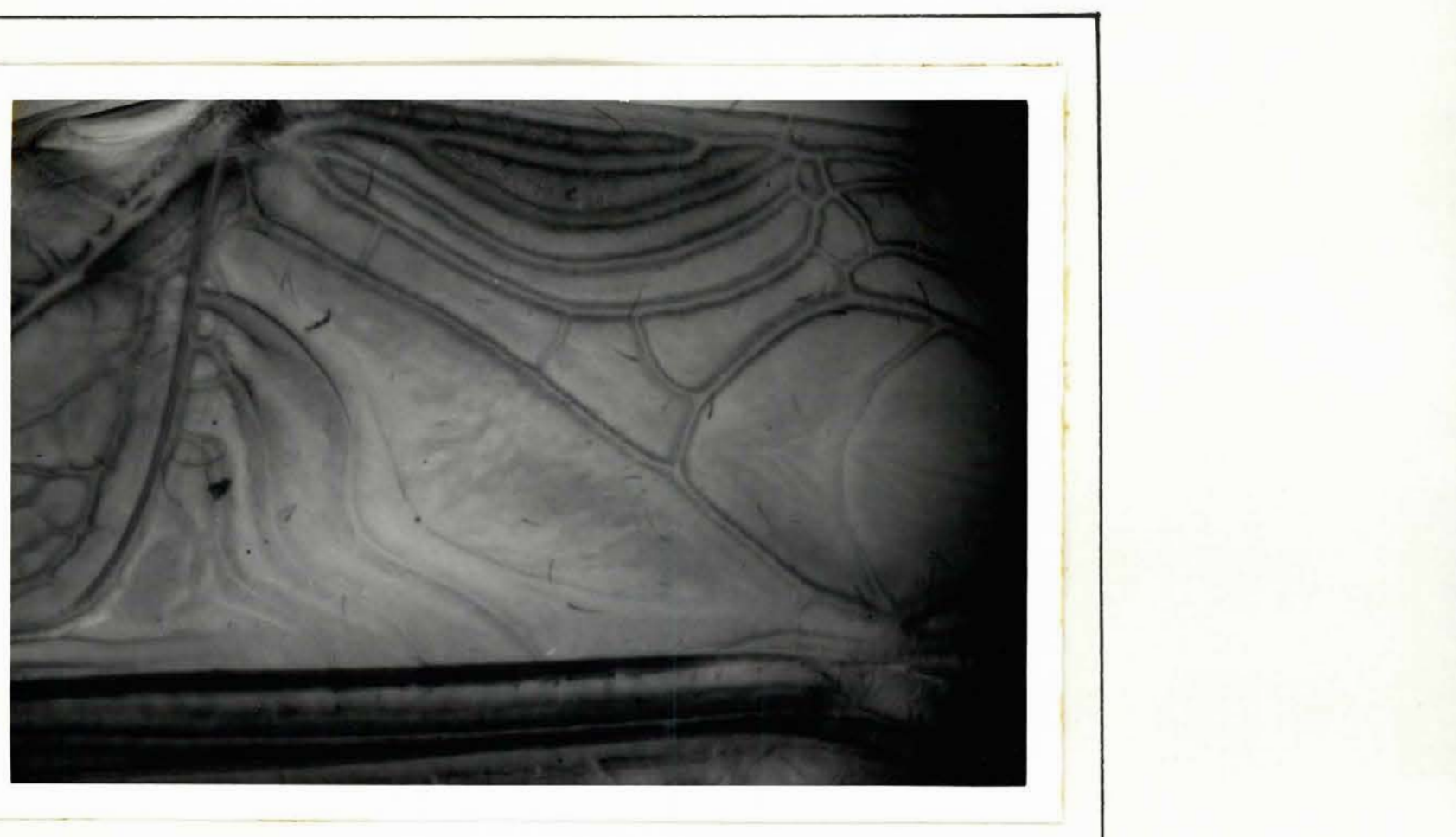

$\mathrm{Ha}$

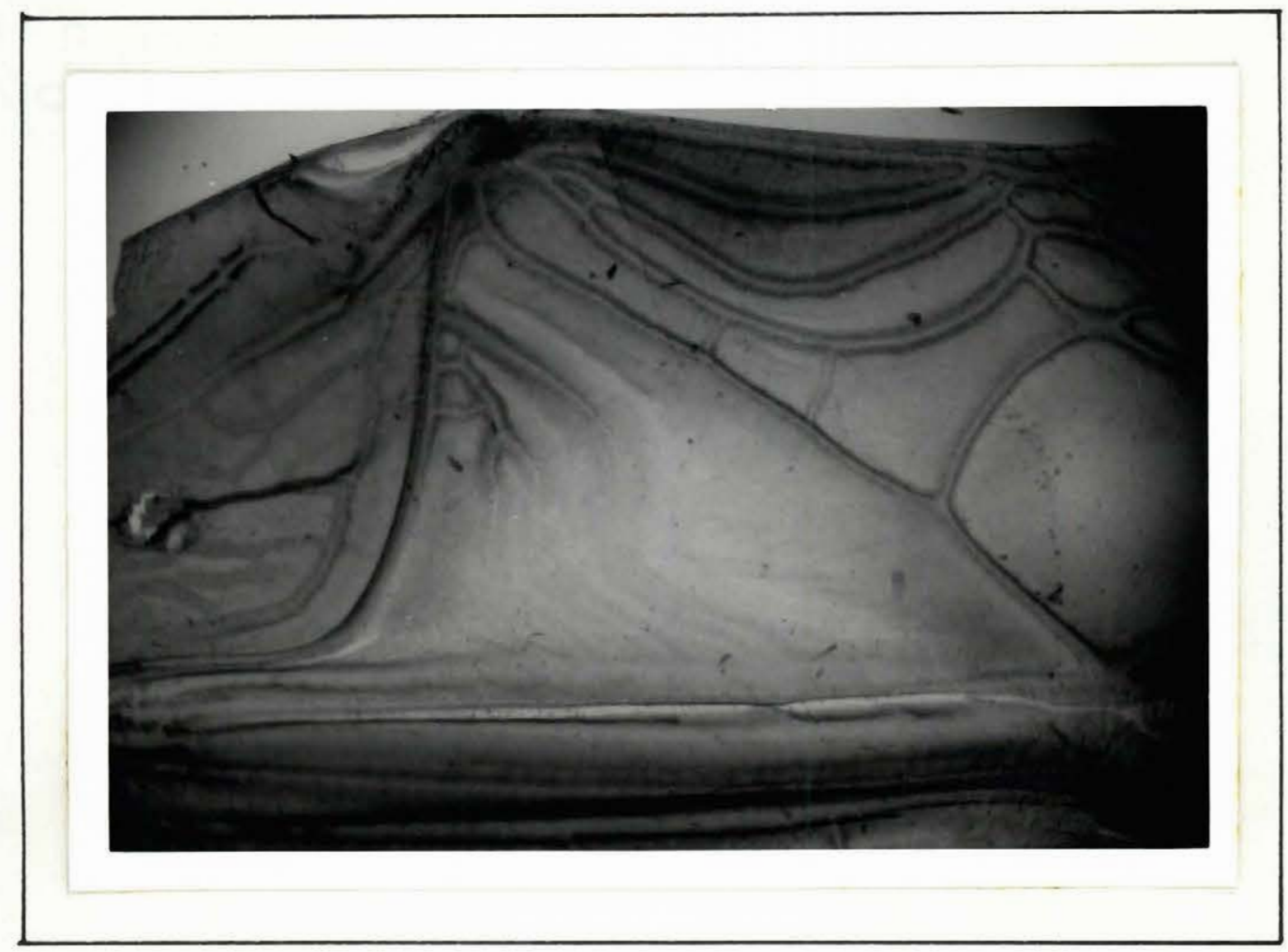

- 
Fig. 12. Left foreleg of Qn strain

(Teleogryllus oceanicus (Le Guillou)).

\author{
a: length of femur \\ $\mathrm{b}$ : length of tibia
}




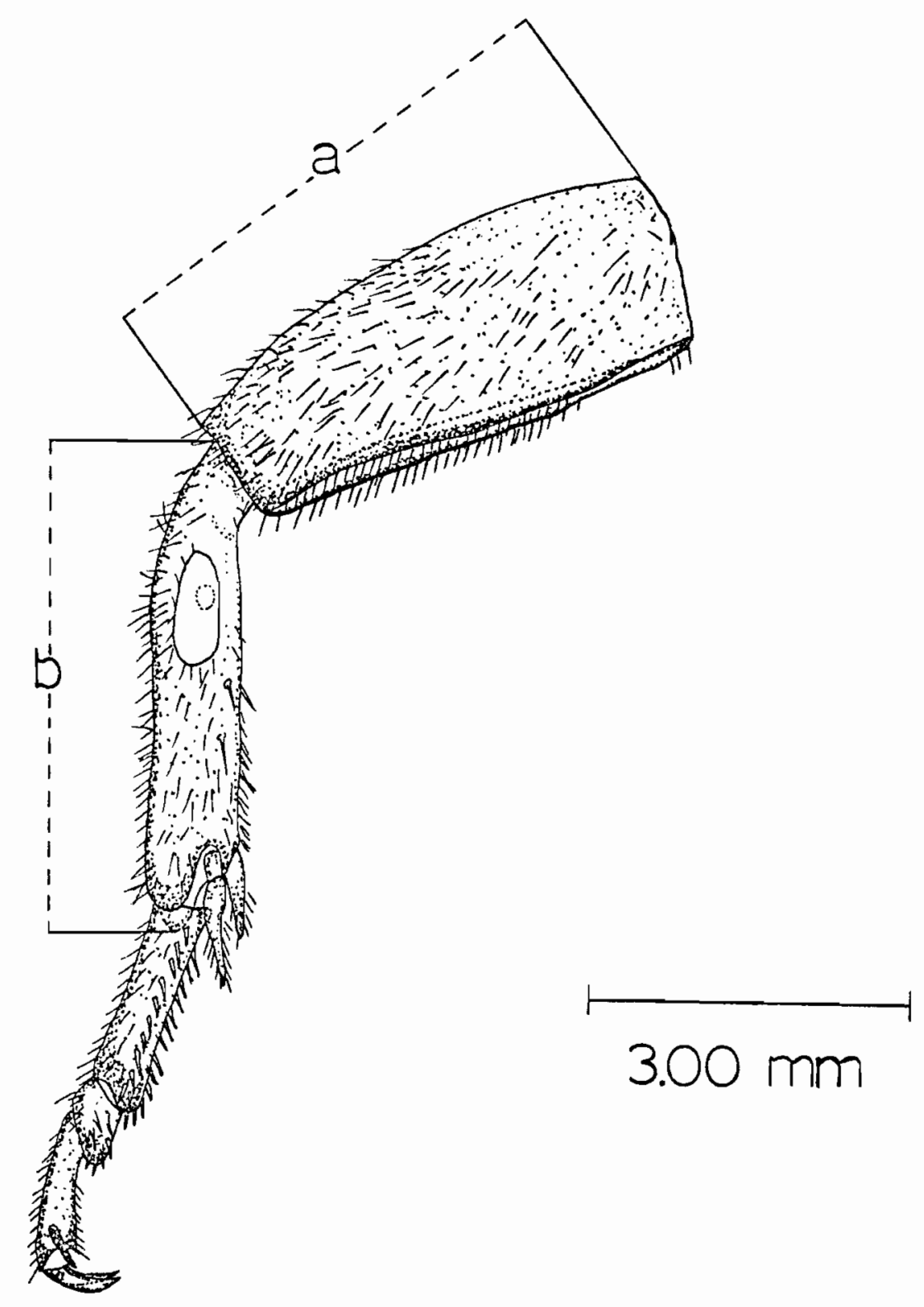


Fig. 13. Acoustic organ of Qn strain

(Teleogryllus oceanicus (Le Guillou)).
a: longitudinal diameter of tympanum
b: transverse diameter of tympanum 


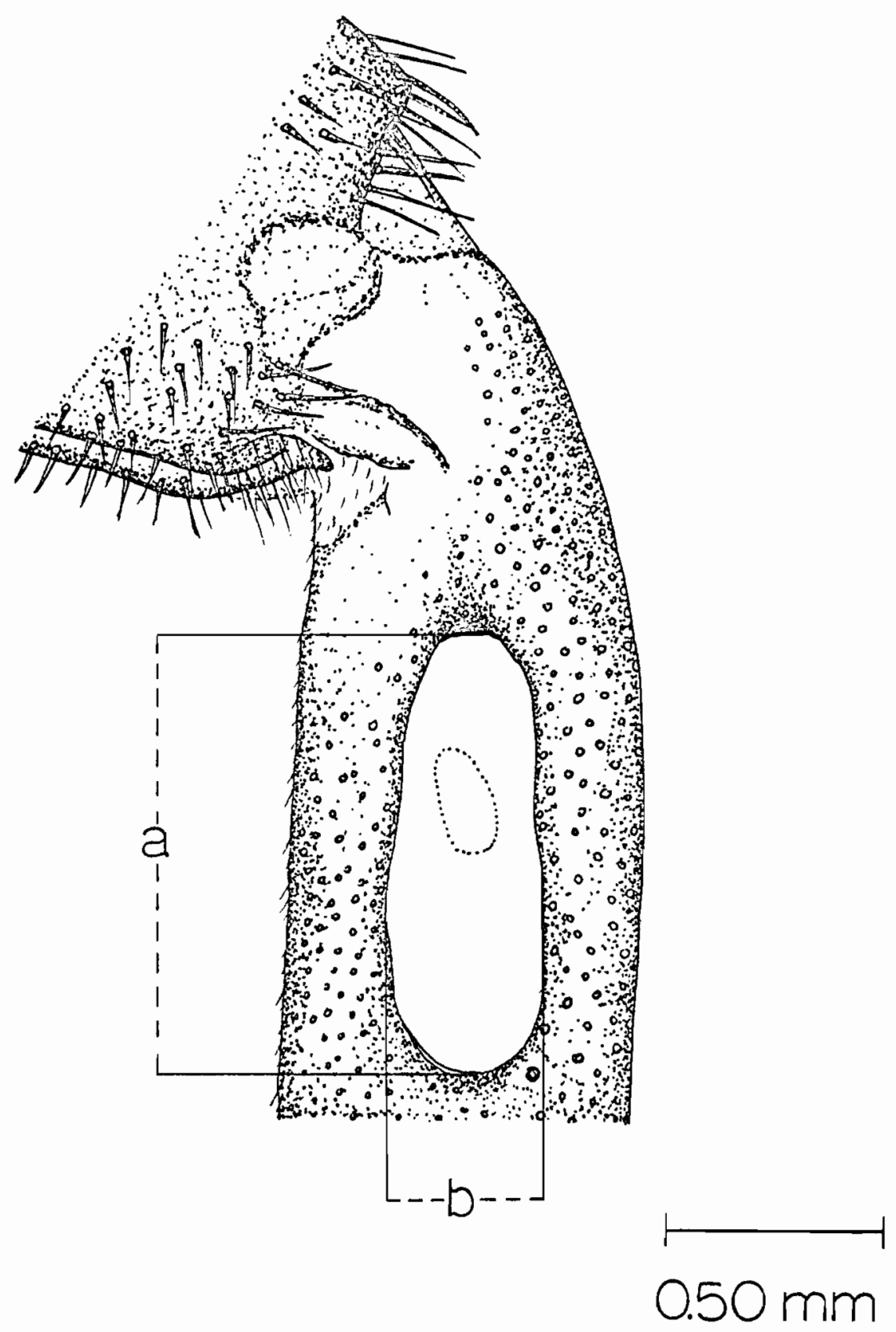


Fig. 14. Lateral view of male external genitalia, Qn strain (Teleogryllus oceanicus (Le Guillou)).

aa: internal anterior apodeme of epiphallus

dp: dorsal pouch

ect: ectoparamere

end: endoparamere

epi: epiphallus

ram: ramus

sps: spermatophore sac

stl: stylet 


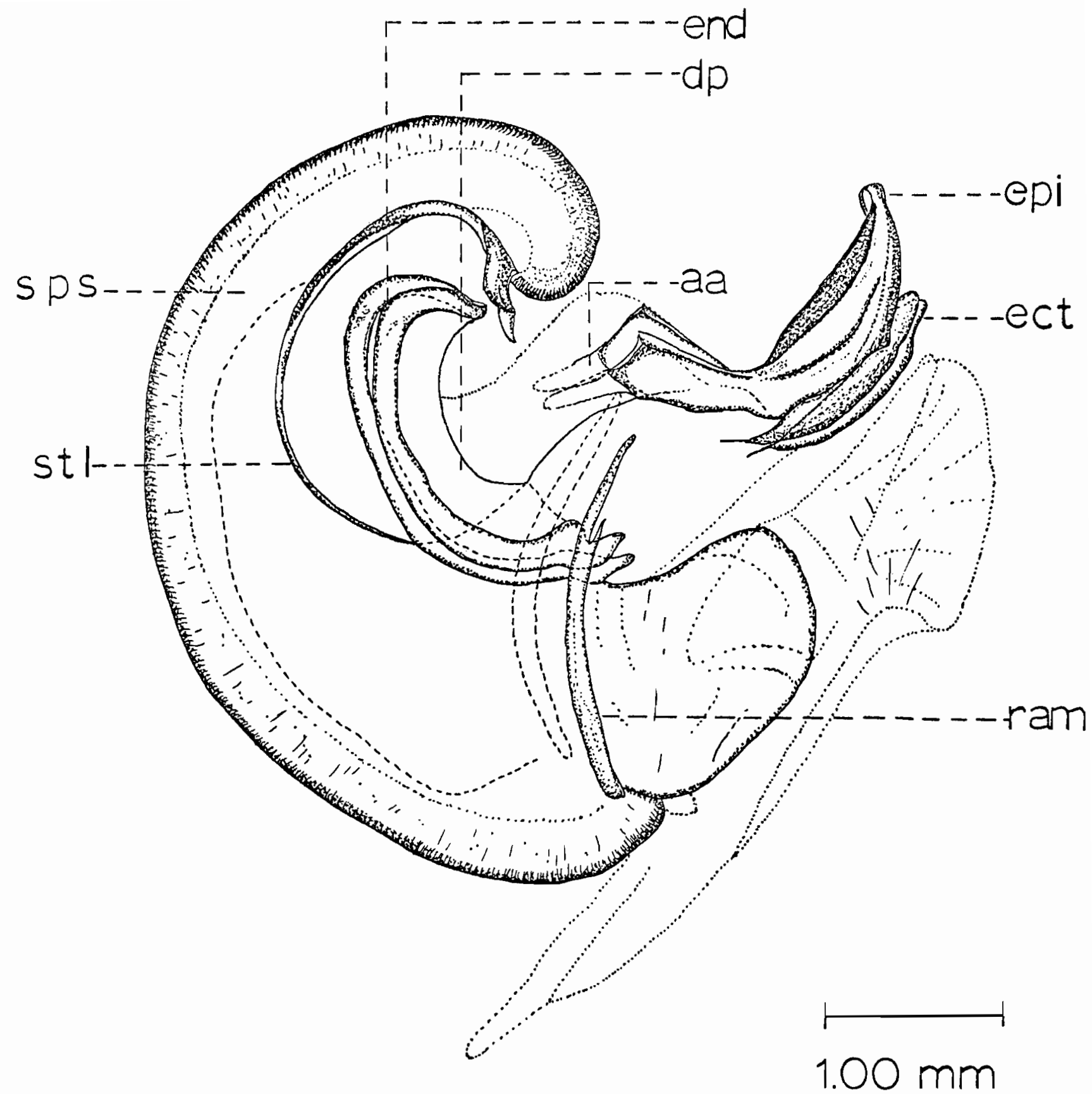


Fig. 15. Dorsal view of male genitalia of Qn strain (Teleogryllus oceanicus (Le Guillou)) with stylet and spermatophore sac removed. Lettering as in Fig. 14 . 

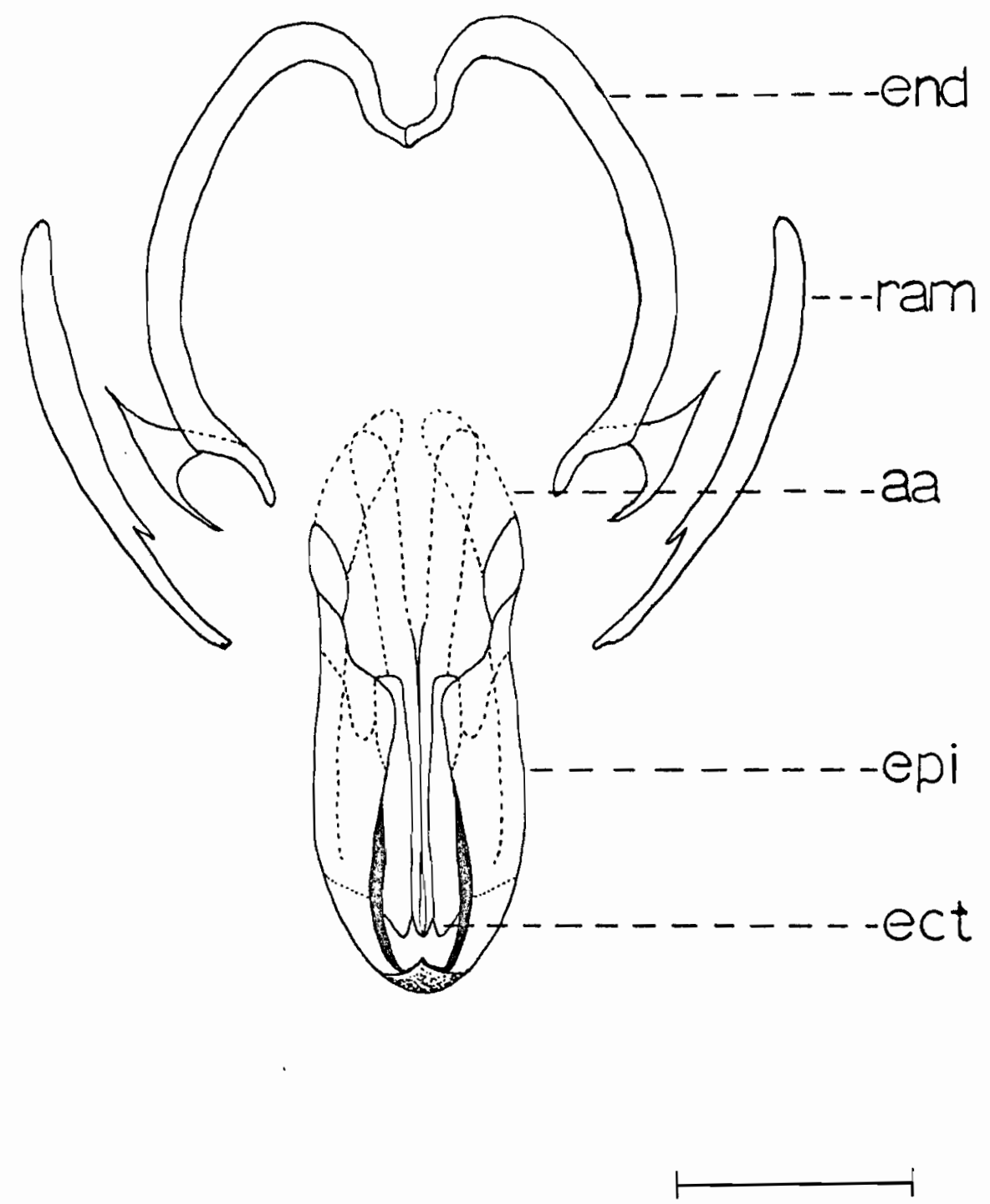

$1.00 \mathrm{~mm}$ 
Fig. 16. Ventral view of male genitalia of $\mathrm{Qn}$ strain (Teleogryllus oceanicus (Le Guillou)/ with stylet and spermatophore sac removed. Lettering as in Fig. 14 . 

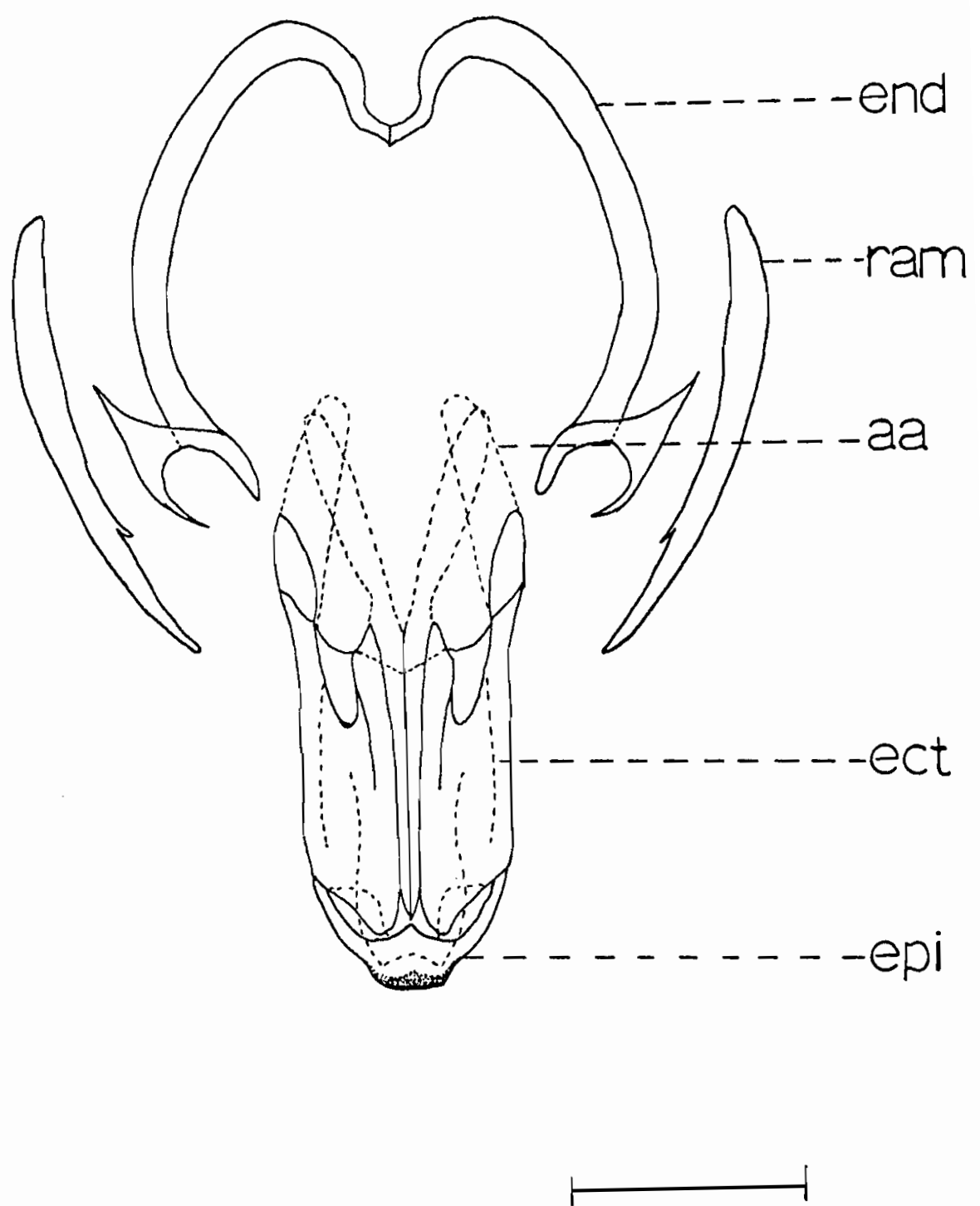

$1.00 \mathrm{~mm}$ 
Fig. 17. Dorsal view of epiphallus and rami of Qn strain (Teleogryllus oceanicus (Le Guillou)).

Lettering as in Fig. 14 . 


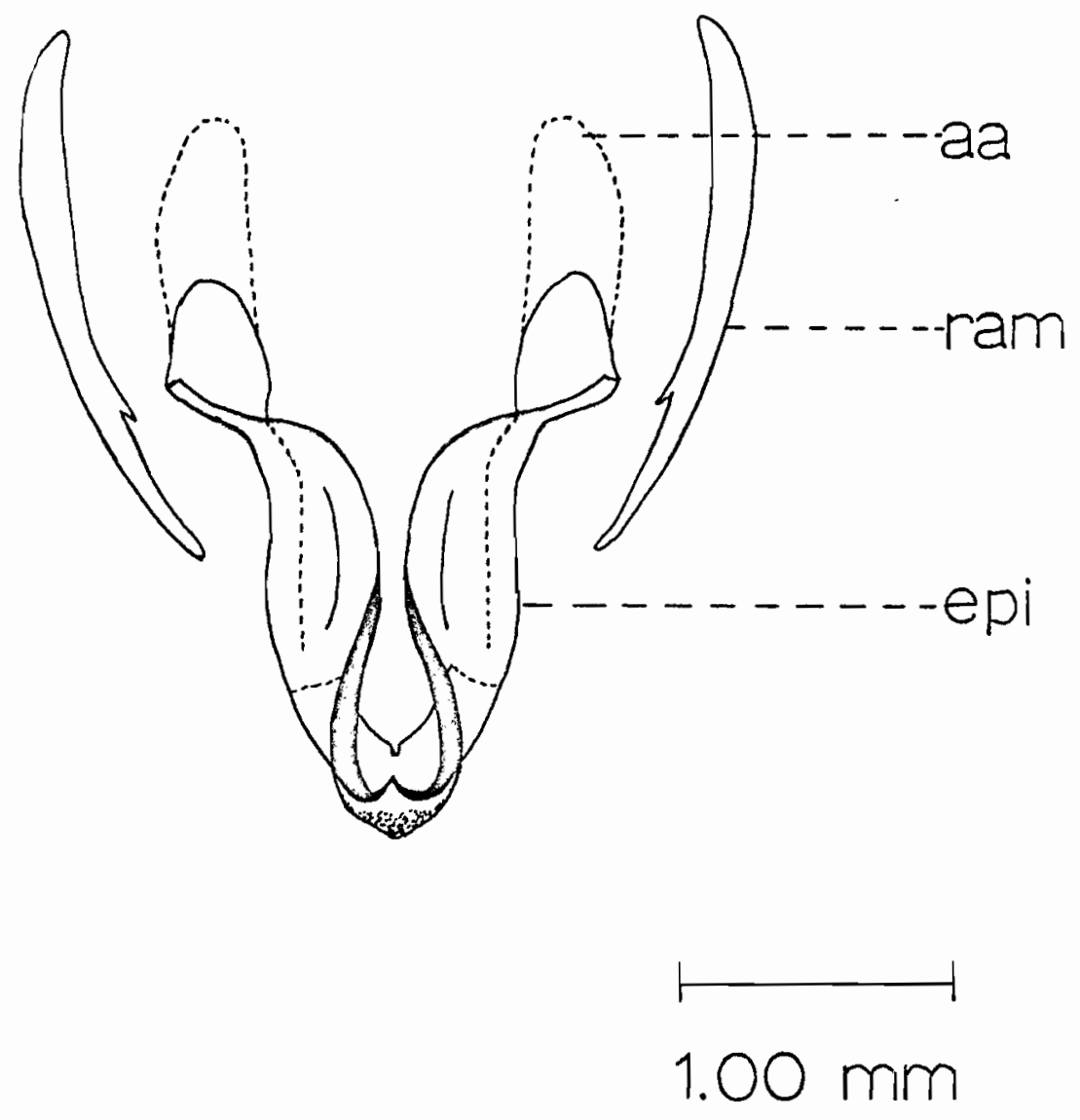


Fig. 18. Ventral view of epiphallus and rami of Qn strain (Teleogryllus oceanicus ( $\mathrm{Le}$ Guillou)).

Lettering as in Fig. 14 . 


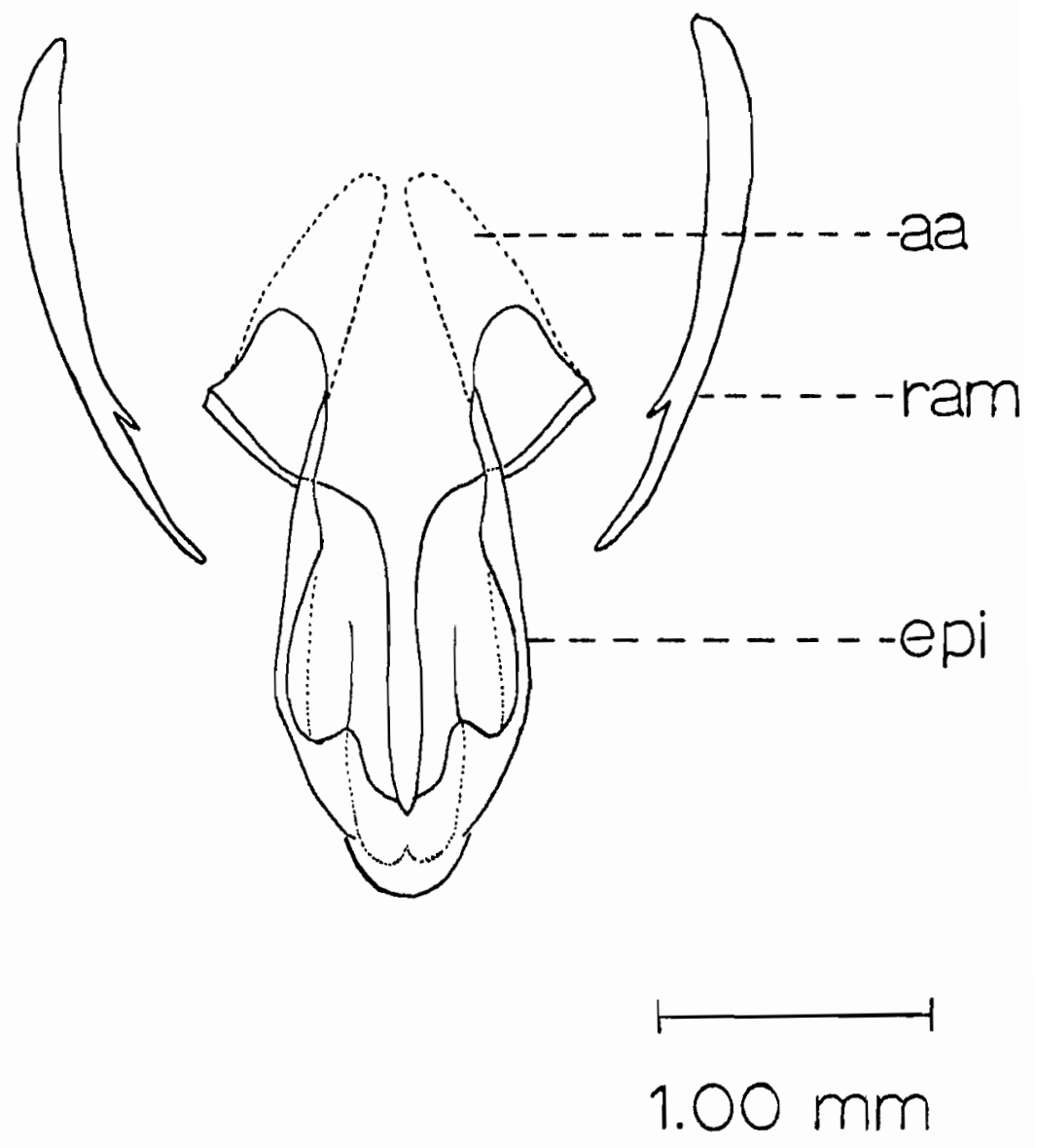


Fig. 19. Dorsal view of ecto- and endo-parameres of Qn strain (Teleogryllus oceanicus (Le Guillou)).

a: length of ectoparamere

$b$ : width of ectoparamere

Other lettering as in Fig. 14. 


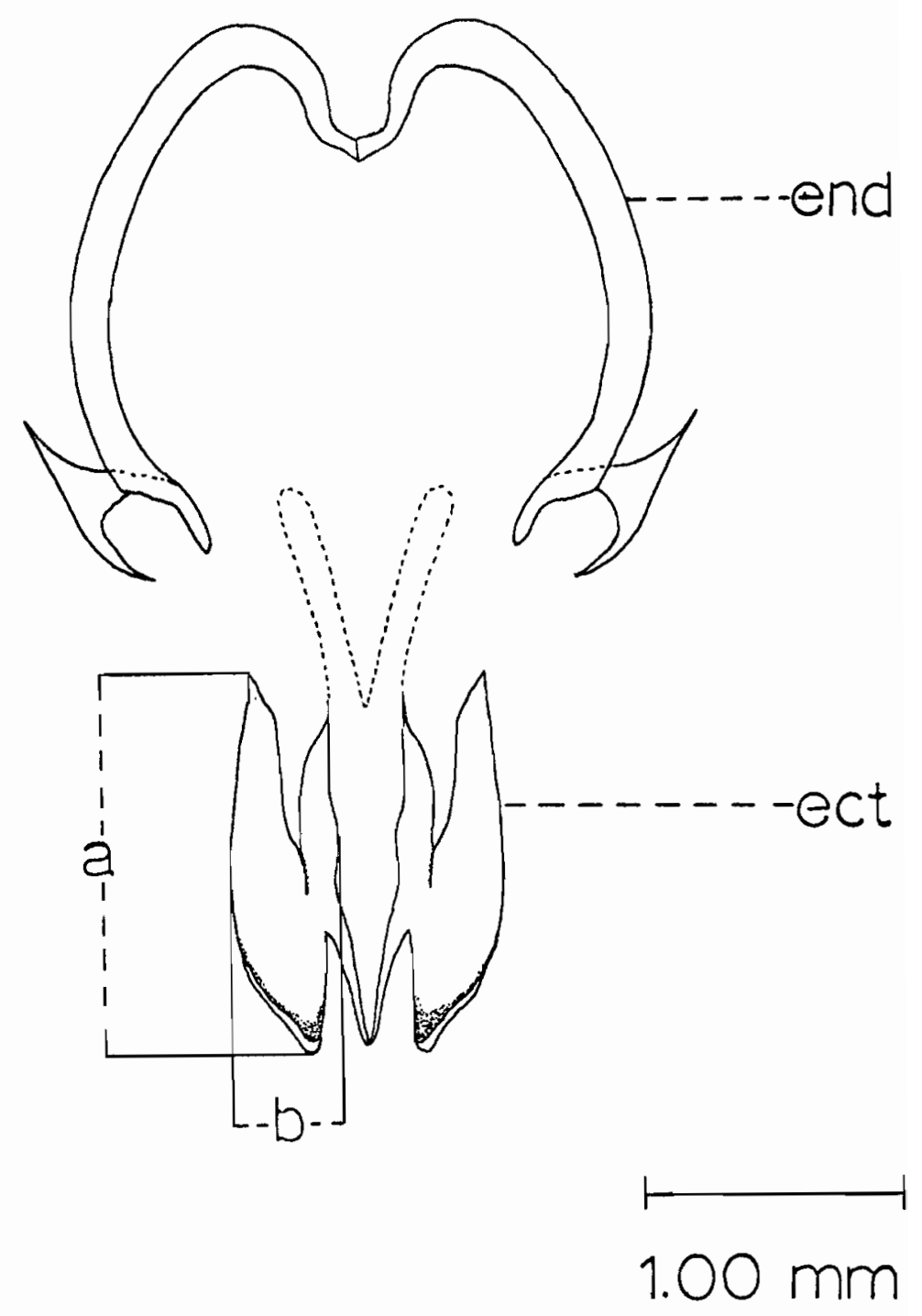


Fig. 20. Lateral view of female external genitalia of Qn strain (Teleogryllus oceanicus (Le Guillou)).

aa: internal anterior apodeme of second valvifer

cx: connexion between two second valvifers

vl: valvula

vlf: valvifer

$A B, A C$ : measurements of taxonomic characters used in separation of strains. 


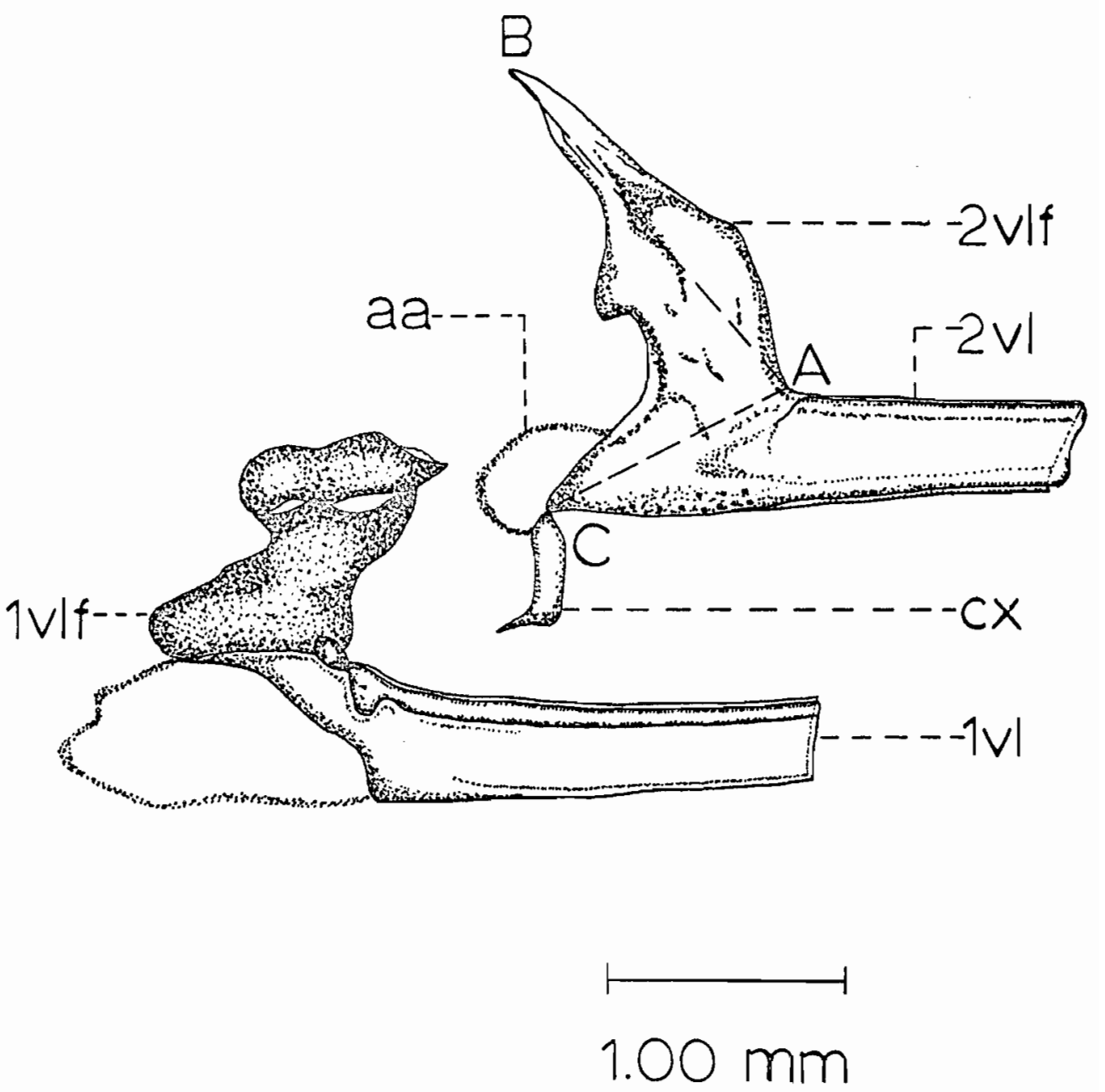


Fig. 21. Dorsal view of epiproct of Qn strain (TeleogryIlus oceanicus (Le Guillou)), male, showing the measured dimensions.
a: length of epiproct
b: width of epiproct 

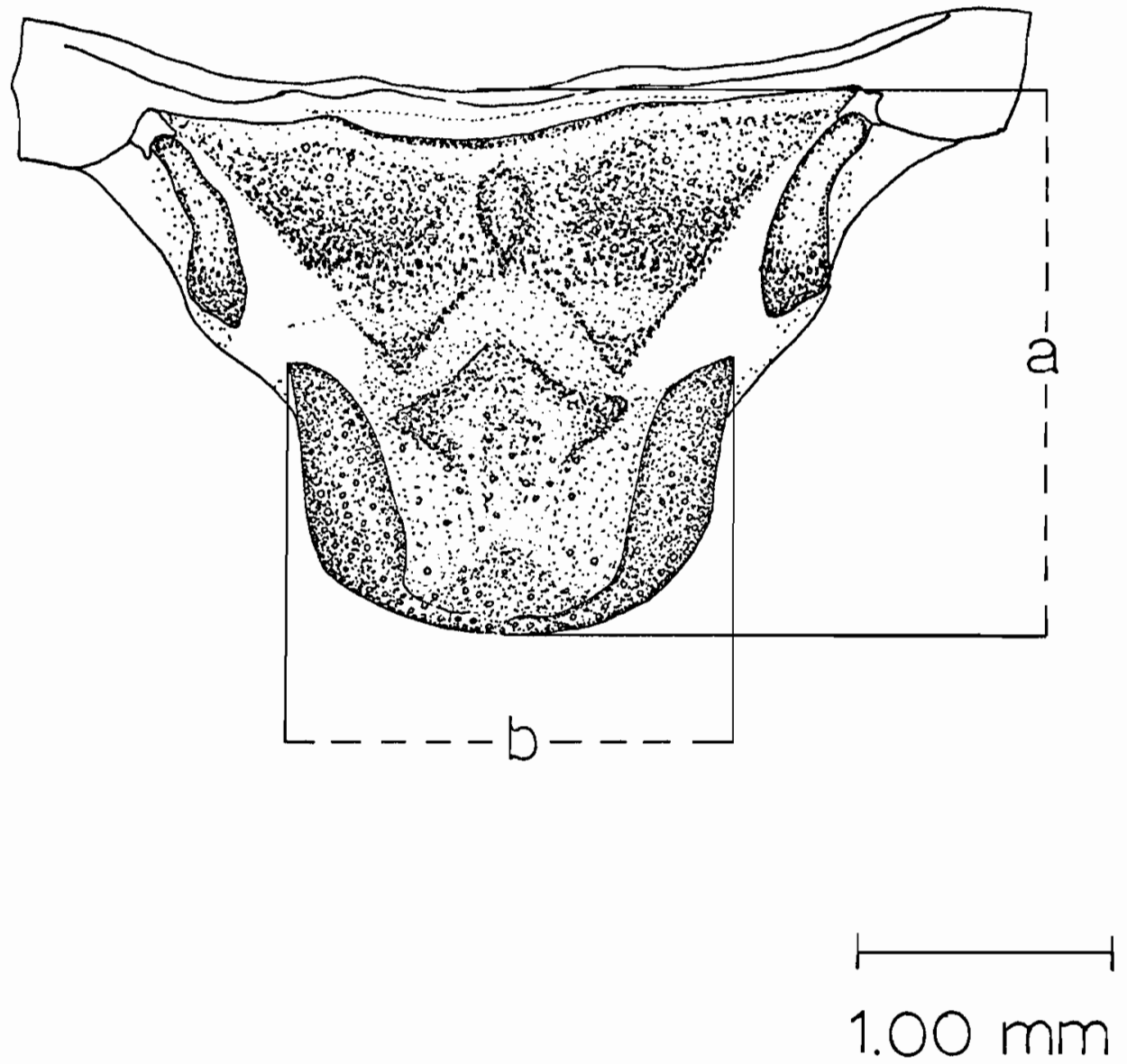
Fig. 22. Shape of epiproct, Qa strain, male (X 200).

Fig. 23. Shape of epiproct, Qa strain, female (x 200). 

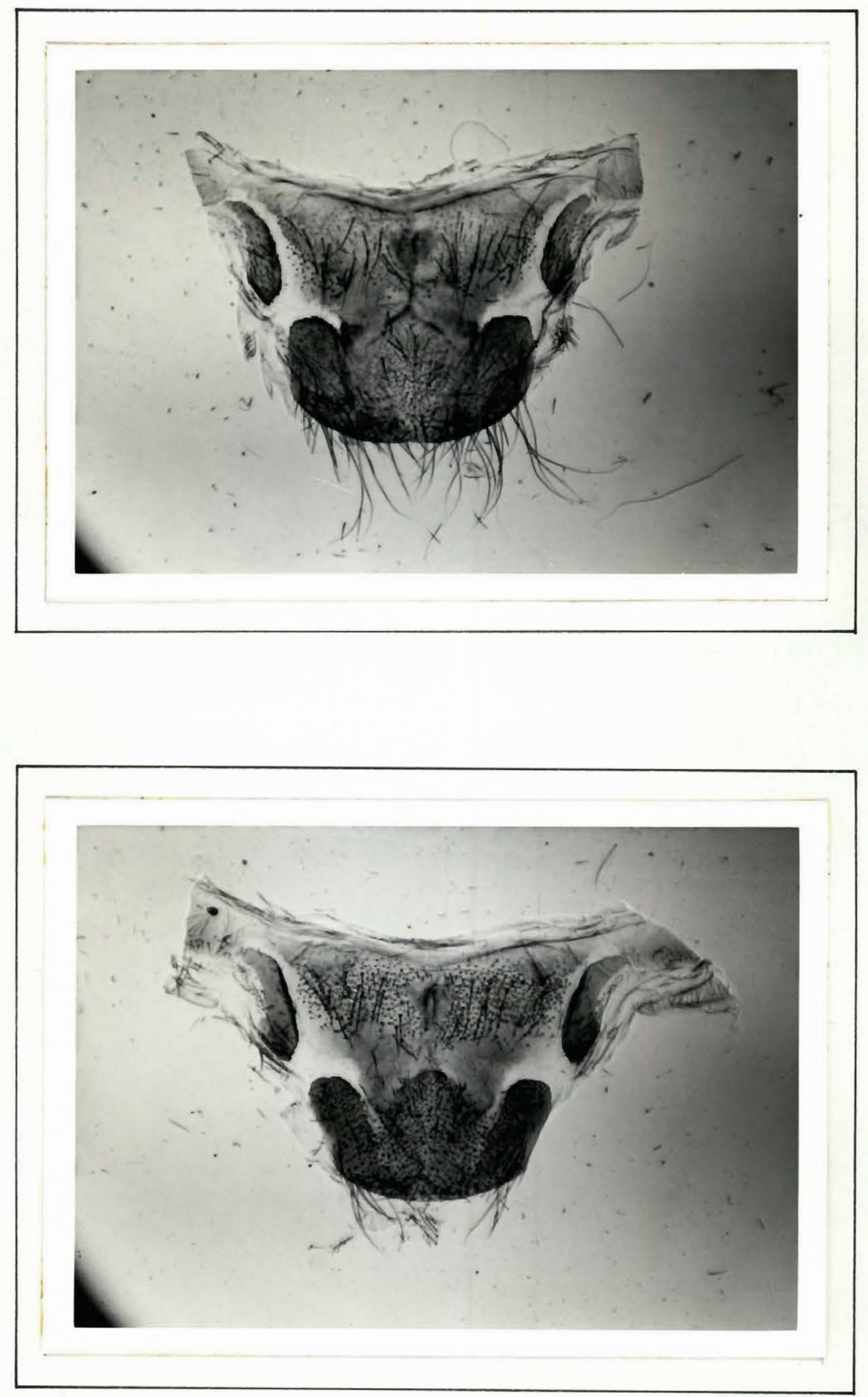
Fig. 24. Shape of epiproct, Qw strain

(Teleogrylius commodus (Walker)), male (x 200).

Fig. 25. Shape of epiproct, Qw strain

(Teleogryllus commodus (Walker)),

female (x 200). 

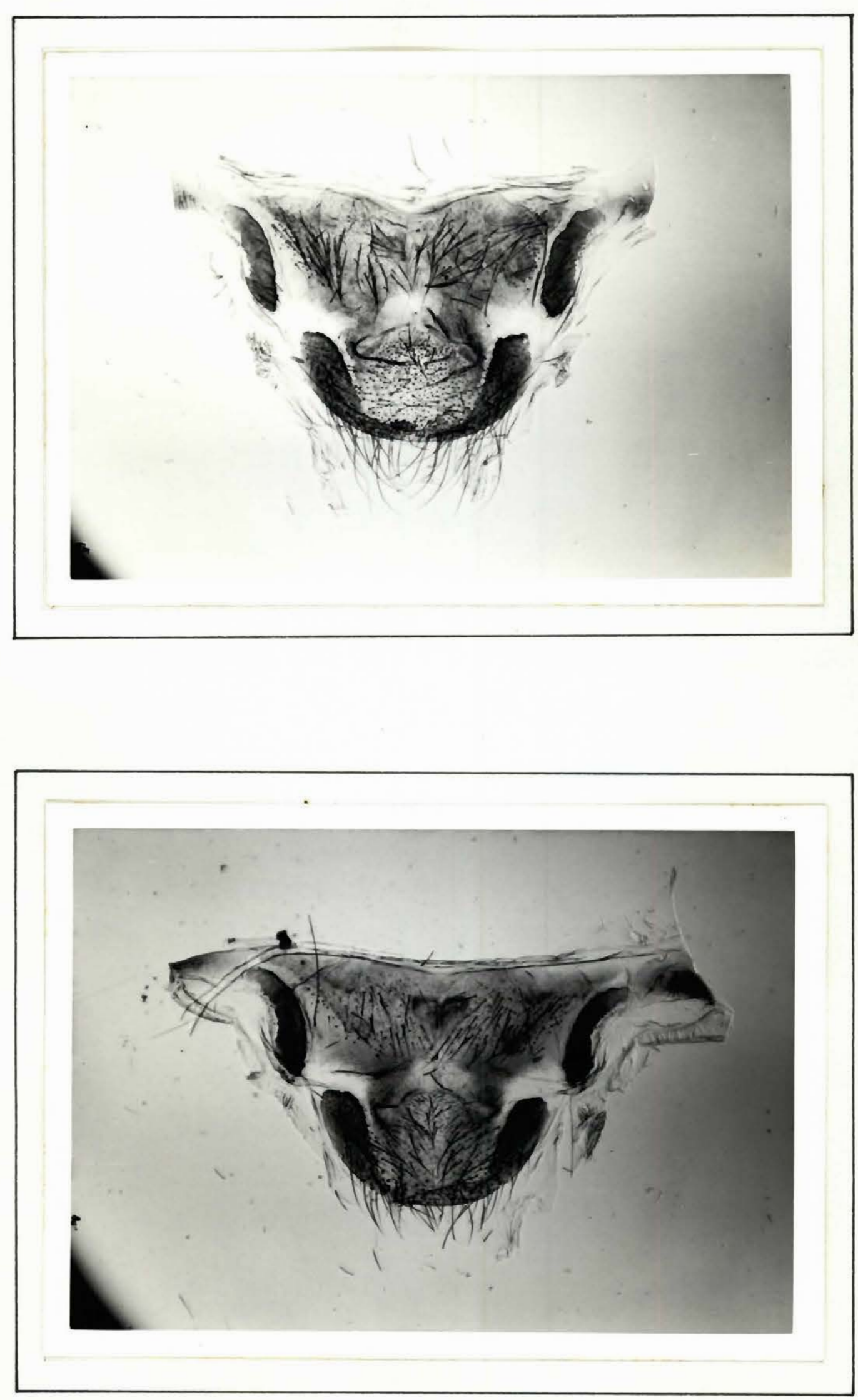
Fig. 26. Shape of epiproct, Qn strain

(Teleogryllus oceanicus (Le Guillou)), male (X 200).

Fig. 27. Shape of epiproct, Qn strain

(Teleogryllus oceanicus (Le Guillou)), female (X 200). 

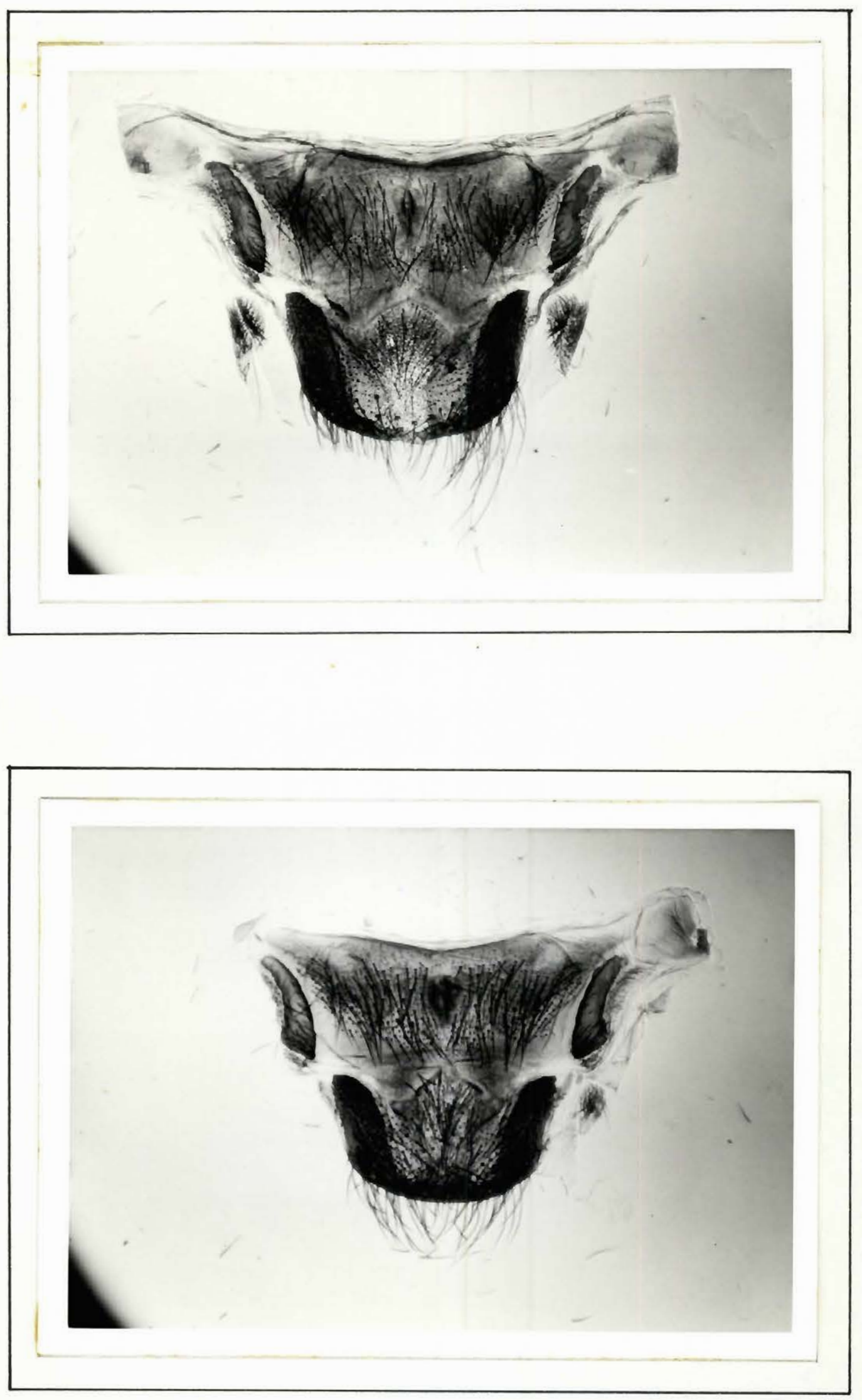
Fig. 28. Shape of epiproct, Qk strain, male (X 200).

Fig. 29. Shape of epiproct, Qk strain, female (X 200). 

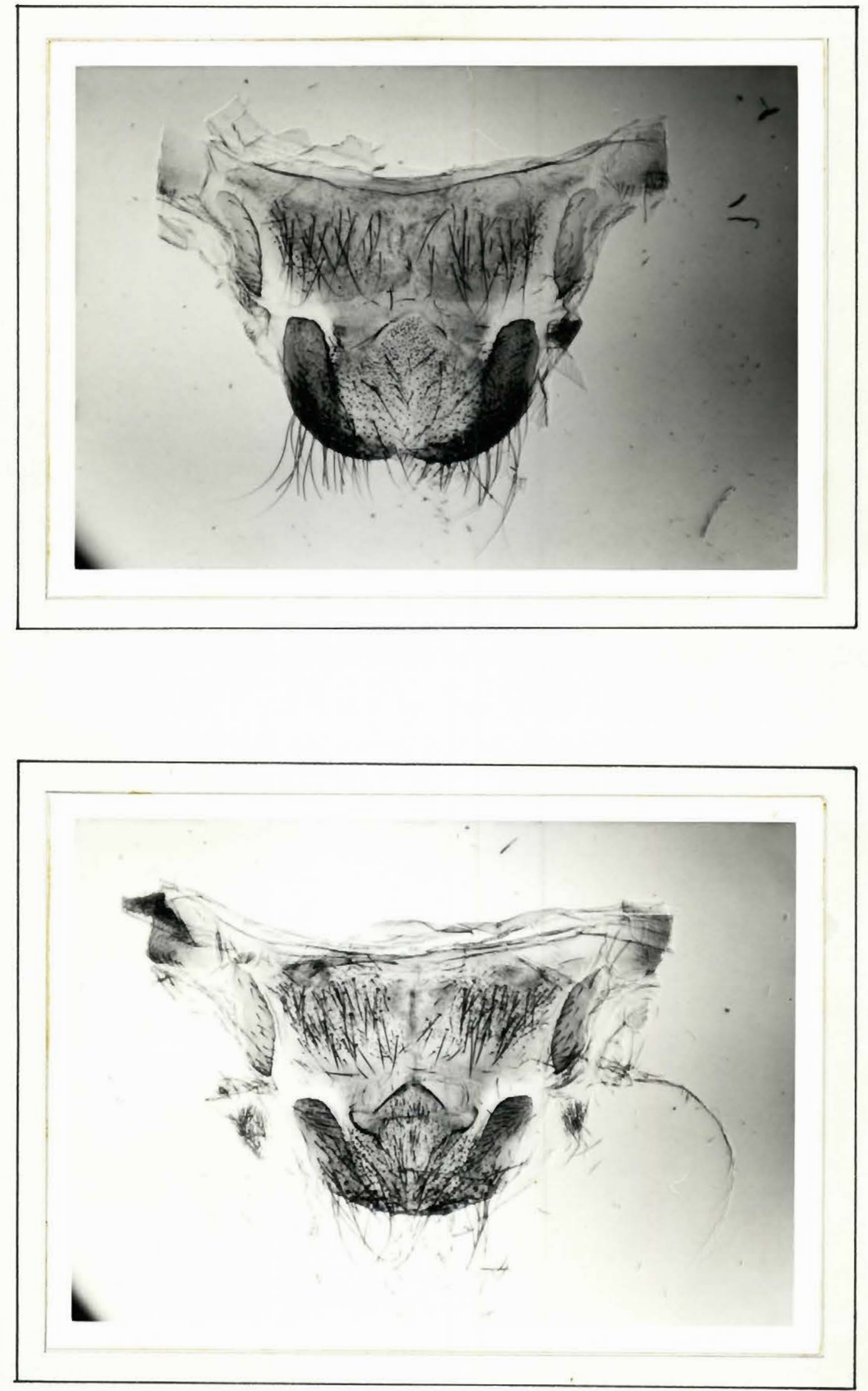
Fig. 30. Shape of epiproct, Qz strain, male (X 200).

Fig. 31. Shape of epiproct, Qz strain, female (x 200). 

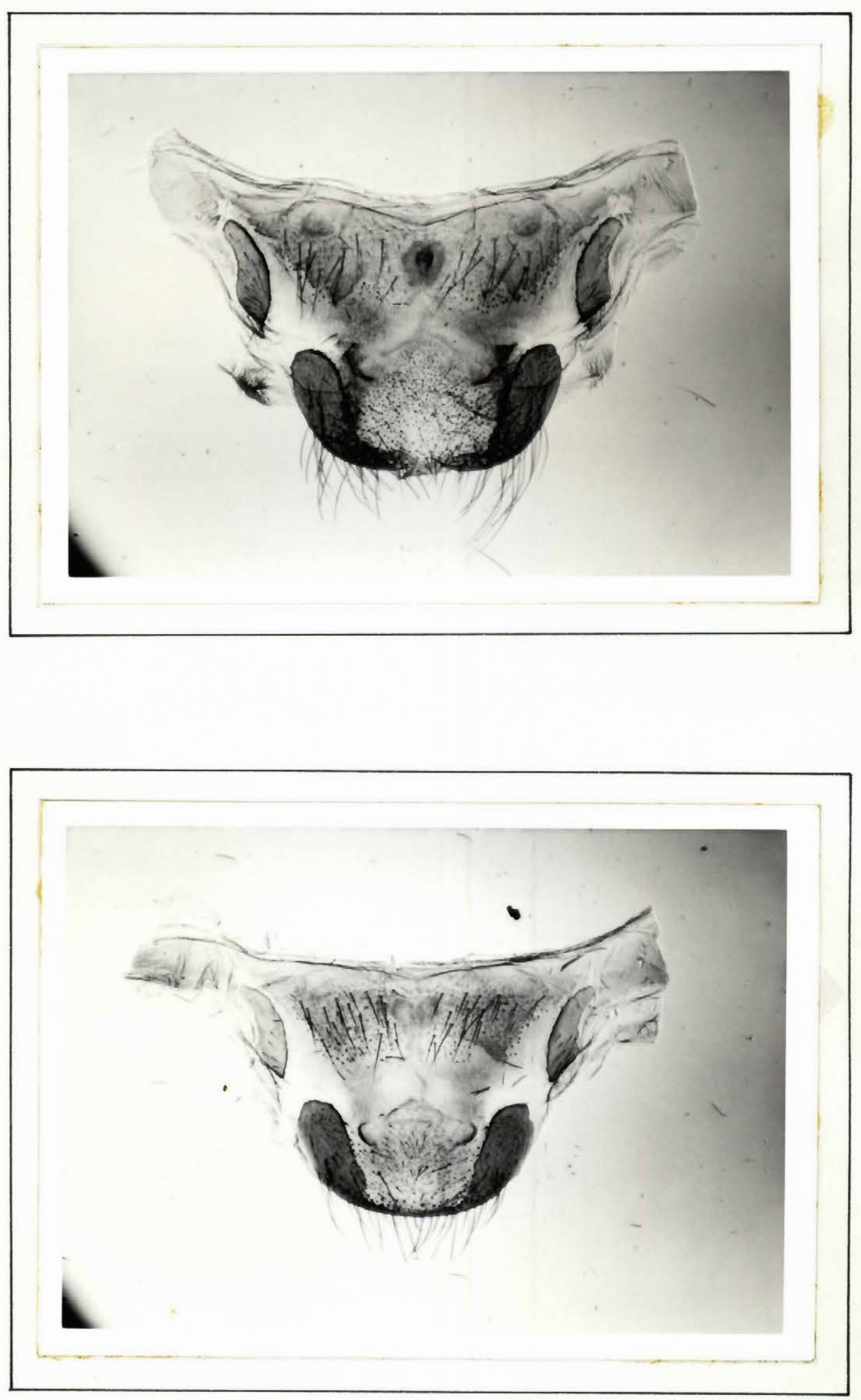
Fig. 32. Shape of epiproct, Qc strain, male (X 200).

Fig. 33. Shape of epiproct, Qc strain, male

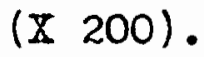



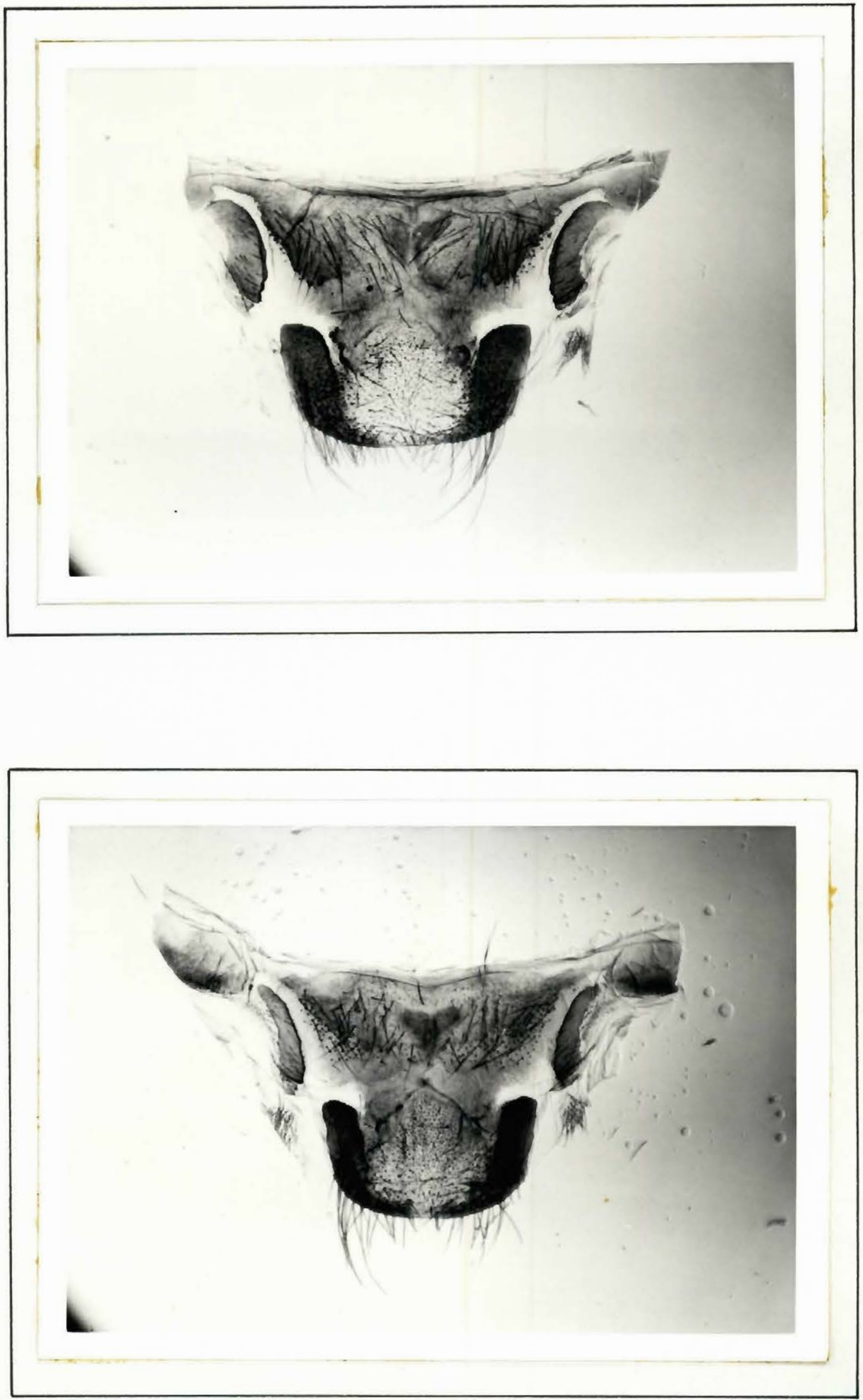
Fig. 34. Shape of epiproct, Qc strain, male (I 200).

Fig. 35. Shape of epiproct, Qc strain, male (X 200). 

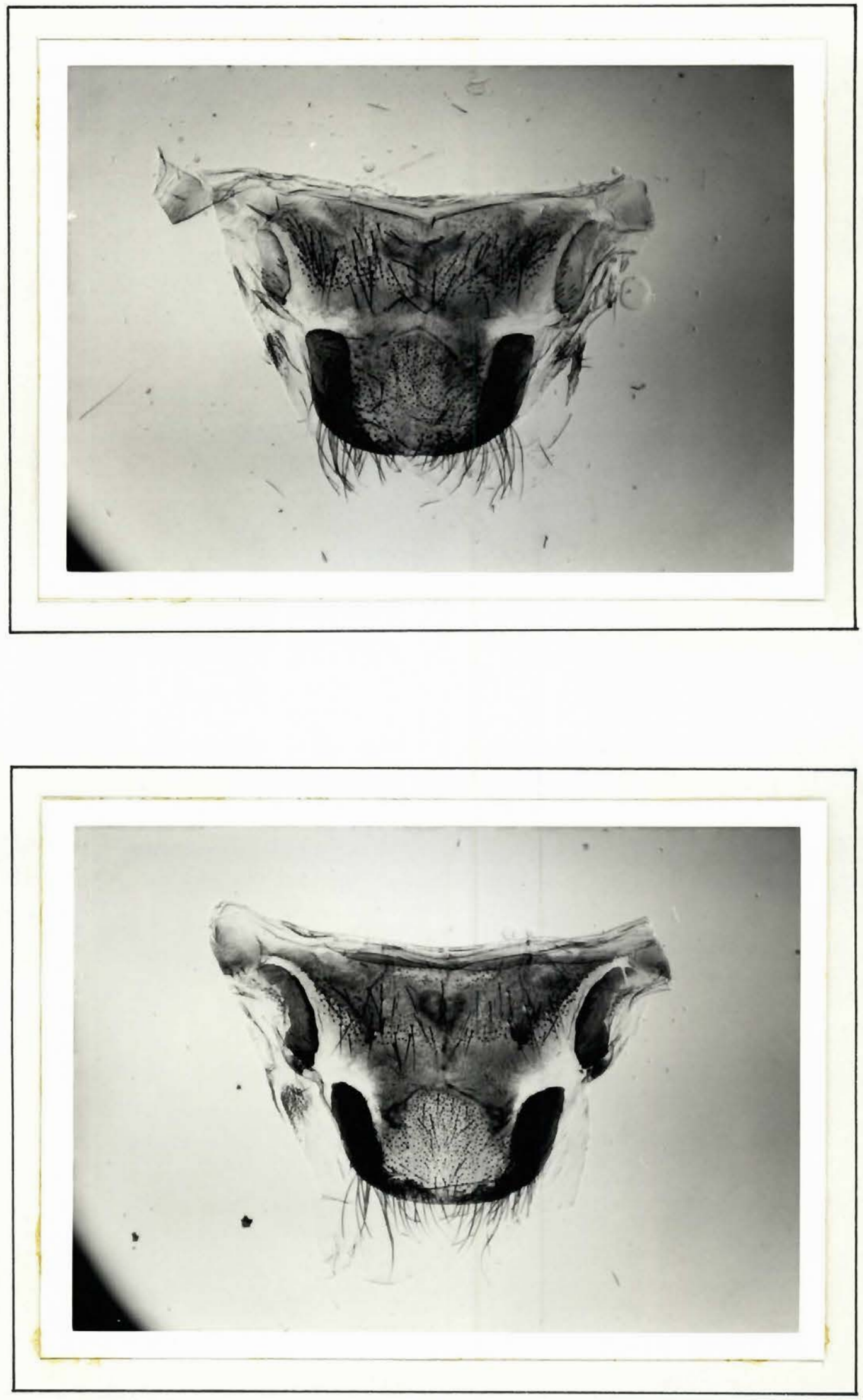
Fig. 36. Shape of epiproct, Qc strain, female (Z 200).

Fig. 37. Shape of epiproct, Qc strain, female (X 200). 

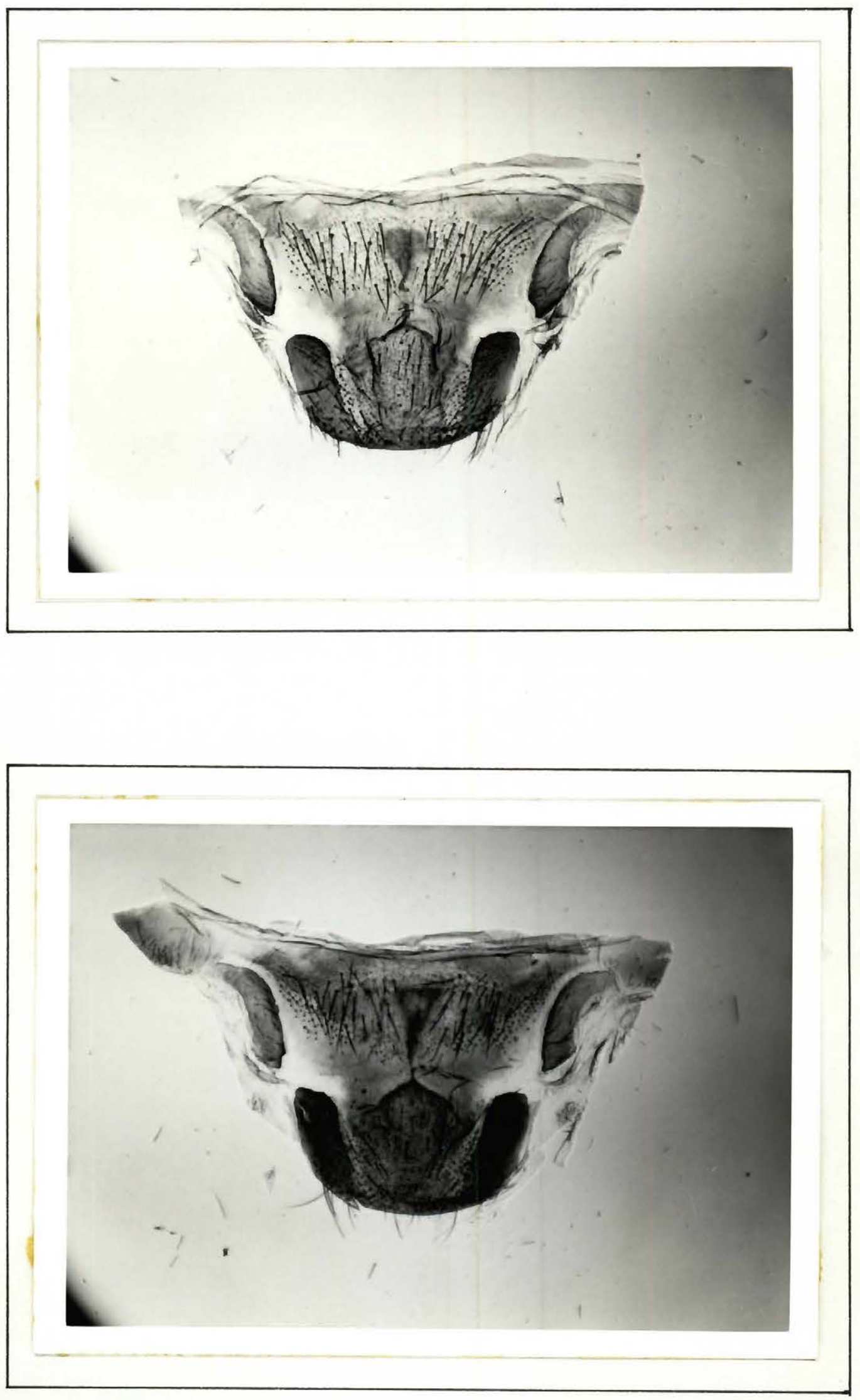
Fig. 38. Shape of epiproct, Qc: strain, female (x 200).

Fig. 39. Shape of epiproct, Qc strain, female (X 200). 

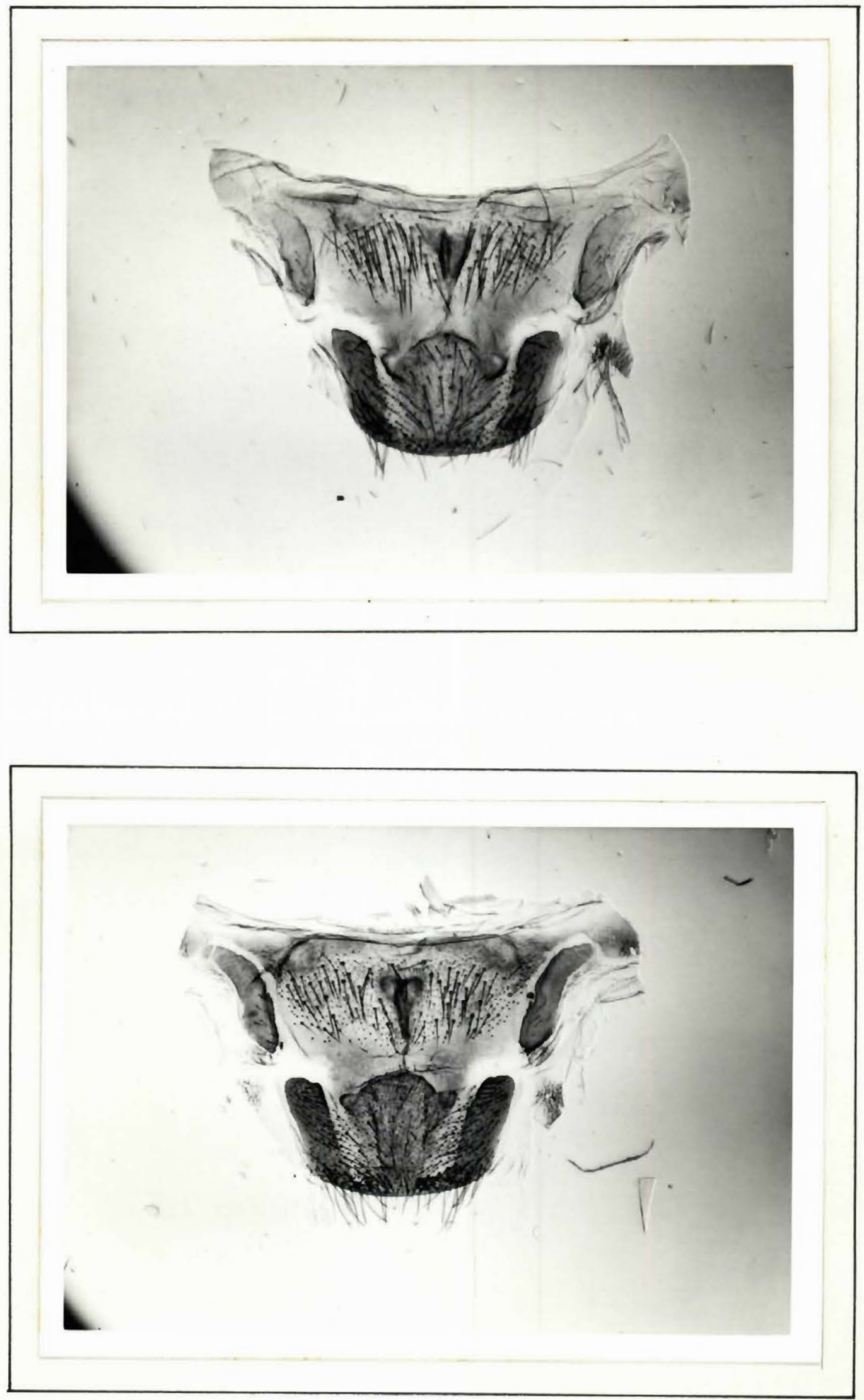
Fig. 40. Proventricular tooth of Qn strain

(Teleogryllus oceanicus (Le Guillou)).

den: denticle

$\mathrm{h}$ : height of tooth 

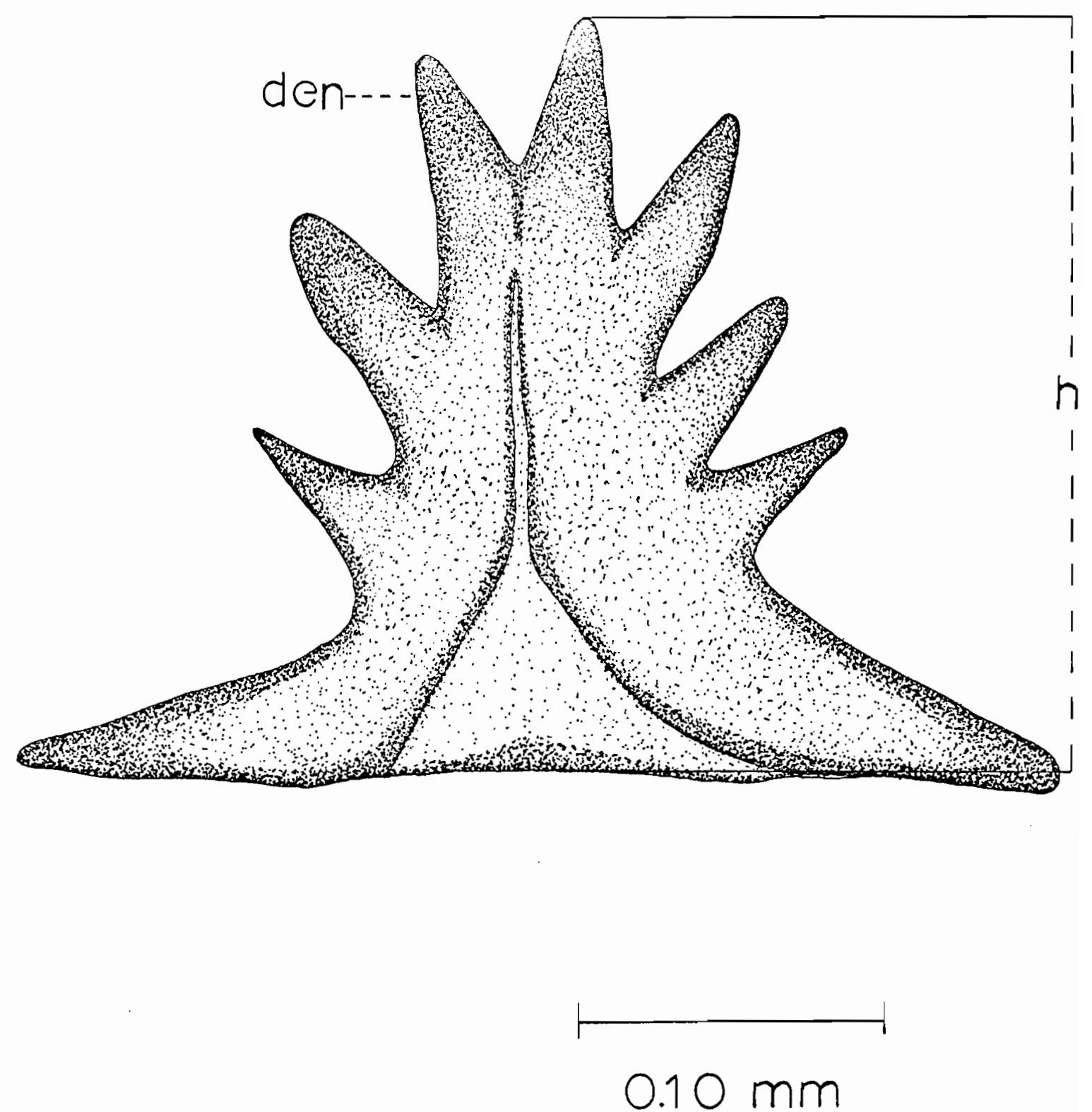